WHC-EP-0719

\title{
Radioactive Waste Shipments to Hanford Retrievable Storage from Babcock and Wilcox, Leechburg, Pennsylvania
}

Prepared for the U.S. Department of Energy

Office of Environmental Restoration and Waste Management

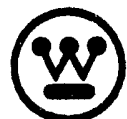

Westinghouse

Hanford Company Richland, Washington

Hanford Operations and Enginearing Contractor for the

U.S. Department of Energy under Contract DE-AC06-87RL10930

Approved for Public Release

REREIVED

APR 181994

OSTI 
LEGAL DISCLAIMER

This report was prepared as an account of work sponsored by an agency of the United States Government. Neither the

United States Government nor any agency thereol, nor any of their employees, nor any of their contractors, subcontractors or their employees, makes any warranty, express or implied, or assumes any legal liability or responsibility for the accuracy, completeness, or any third party's use or the results of such use of any information, apparatus, product, or process disclosed, or represents that its use would not infringe privately owned rights. Reference herein to any specific commercial product, process, or service by trade name, trademark, manufacturer, or otherwise, does not necessarily constitute or imply its endorsement, recommendation, or favoring by the United States Government or any agency thereof or its contractors or subcontractors. The views and opinions of authors expressed herein do not necessarily state or reflect those of the United States Government or any agency thereof.

This report has been reproduced from the best available copy. Available in paper copy and microfiche.

Available to the U.S. Department of Energy

and its contractors from

Office of Scientific and Technical Information

P.0. Box 62

Oak Ridge, TN 37831

(615) 576.8401

Available to the public from the U.S. Department of Commerce National Tochnical Information Service

5285 Port Royal Road

Springfield, VA 22161

(703) $487-4650$

Printed in tho Unilad staice of Ameriles

DISCLM-1.CHP (1-D1) 


\section{Radioactive Waste}

Shipments to Hanford

Retrievable Storage from

Babcock and Wilcox,

Leechburg, Pennsylvania

D. R. Duncan

Date Published

February 1994

Prepared for the U.S. Department of Energy

Office of Environmental Restoration and Waste Management

\section{(). \\ Westinghouse \\ P.O. Box 1970 \\ Hantord Company Richland, Washington 99352}

Hanford Operations and Engineering Contractor for the

U.S. Department of Energy under Contract DE-AC06-87RL10930

Approved for Public Release 


\section{RELEASE AUTHORIZATION}

Document Number: WHC-EP-0719

Radioactive Waste Shipments to the Hanford Site

Document Title: Retrievable Storage from Babcock and Wilcox, Leechburgh, Pennsylvania

Release Date: $\quad$ February 14, 1994

$* * * * * * * * * * * * *$

This document was reviewed following the procedures described in WHC-CM-3-4 and is:

\section{APPROVED FOR PUBLIC RELEASE}

$* * * * * * * * * * * * *$

WHC Information Release Administration Specialist: MN Boston 


\section{ACKNOWLEDGEMENTS}

The follovving people generously shared their time and knowledge of Babcock and Wilcox's solid waste generation:

W. J. Rosis, Babcock and Wilcox Nuclear Environmental Services, Inc.

M. Straul), Babcock and Wilcox Nuclear Environmental Services, Inc.

G. W. Viggna, B\&W Nuclear Environmental Services, Inc.

F. F. Walters, Westinghouse Hanford Company

J. D. Anclerson, Westinghouse Hanford Company

M. N. Serier, Westinghouse Hanford Company

M. L. Sheriff, Westinghouse Hanford Company

Also, thariks are due to S. L. Galstad and S. L. Claybrook for their assistance with the Solid Waste information and Tracking System database and Solid Waste Burial Records. 
WHC-EP-0719

This page intentionally left blank. 


\title{
RADIOACTIVE WASTE SHIPMENTS TO THE HANFORD SITE RETRIEVABLE STORAGE FROM BABCOCK AND WILCOX, LEECHBURG, PENNSYLVANIA
}

\author{
D. R. Duncan
}

\begin{abstract}
This report characterizes, as far as possible, the solid radioactive wastes generated by Babcock and Wilcox's Park Township Plutonium Facility near Leechburg, Pennsylvania that were sent to retrievable storage at the Hanford Site. Solid waste as defined in this document is any containerized or self-contained material that has been declared waste. The objeciive is a description of characteristics of solid wastes that are or will be managed by the Restoration and Upgrades Program; gaseous or liquid effluents are discussed only at a summary level. This characterization is of particular interest in the planning of transuranic (TRU) waste retrieval operations, including the Waste Receiving and Processing (WRAPI Facility, because Babcock and Wilcox generated greater than 2.5 percent of the total volume of TRU waste currently stored at the Hanford Site.
\end{abstract}


WHC-EP-0719

This page intentionally left blank. 


\section{EXECUTIVE SUMMARY}

During the next two decades the transuranic (TRU) wastes now stored in the burial trenches and storage facilities at the Hanford Site are to be retrieved, processed at the Waste Receiving and Processing (WRAP) Facility, and shipped to the Waste Isolation Pilot Plant (WIPP) near Carlsbad, New Mexico for final disposal. Approximately 2.5 percent of the TRU waste to be retrieved for shipment to WIPP was generated at the Babcock and Wilcox Plutonium Facility near Leechburg, Pennsylvania, and shipped to the Hanford Site for storage. The purpose of this report is to characterize these radioactive solid wastes using process knowledge, existing records, and oral history interviews.

The Plutonium Facility in Parks Township, PA began operations in 1960 under the ownership of the Nuclear Materials and Equipment Corporation (NUMEC). Atlantic Richfield Company bought NUMEC in 1967, then sold NUMEC in 1971 to Babcock and Wilcox. In December 1974, NUMEC was dissolved into Babcock and Wilcox. Section 2.0 provides further details of the physical plant, facility operations, facility history, and current status of the Babcock and Wilcox Plutonium Facility.

The solid radioactive wastes that were sent by Babcock and Wilcox to the Hanford Site were associated with the fabrication of $\mathrm{PuO}_{2}-\cup \mathrm{O}_{2}$ fuel rods and pellet stacks for the Fast Flux Test Facility (FFTF) cores $1,2,3$, and 4 and the subsequent decontamination and cleanout activities. The types and estimated quantities of TRU waste resulting from these activities are discussed in detail in Section 3.0. 
A detailed discussion of the packaging and handling procedures used for the Babcock and Wilcox transuranic wastes shipped to the Hanford Site are provided in Section 4.0.

Information on the radioactive wastes generated at Babcock and Wilcox can be found in a number of existing documents and databases. The most important of these are the Solid Waste Information and Tracking System (SWITS) database and Solid Waste Burial Records (SWBR). Facility personnel also provide excellent information about past waste generation and the procedures used to handle that waste. Section 5.0 was compiled using these sources to characterize the TRU waste generated at Babcock and Wilcox and sent to retrievable storage at the Hanford Site.

Between 1977 and 1983, 1,477 containers of radioactive solid waste generated at NUMEC and Babcock and Wilcox were shipped to the Hanford Site to be stored. These containers represent over 176,593 kilograms of waste occupying $443.6 \mathrm{~m}^{3}$ of space. Section 5.0 provides an indepth look at this waste, including the following:

- Weight and volume of the waste

- Container types and numbers

- Physical description of the waste

- Radiological components

- Isotopes present in waste

- Hazardous constituents

- Current storage/disposal locations. 
There are indications that shipments of transuranic wastes from NUMEC/Babcock and Wilcox to the Hanford Site occurred before 1977. Those wastes most likely were sent from Pennsylvania to Hanford Site facilities such as $234-5 Z$ for assay. It is possible that these wastes are designated as coming from various facilities at the Hanford Site, because no waste burial records before 1977 list Babcock and Wilcox or NUMEC as a waste originator. It also is possible that waste before 1977 may have been shipped to the commercial nuclear waste disposal facility at the Hanford Site rather than the U.S. Department of Energy facility. 
WHC-EP-0719

This page intentionally left blank. 


\section{CONTENTS}

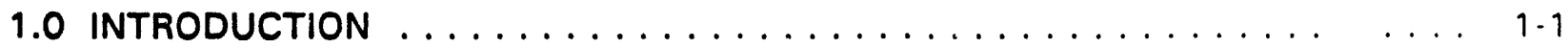

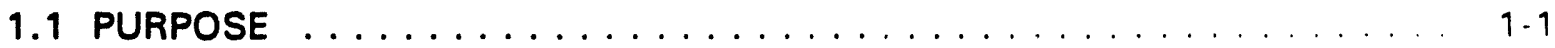

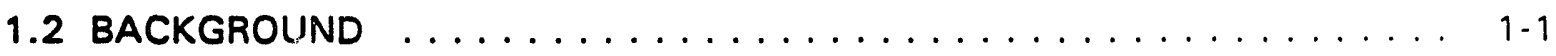

1.3 SOURCES .............................. 1.2

1.3.1 Documents That Describe Pertinent NUMEC and Babcock and Wilcox Processes .......................... 1.2

1.3.2 Documents That Describe Babcock and Wilcox Waste Packaging and Handling Procedures . . . . . . . . . . . . . . . . . . 1-2

1.3 .3 Interviews . . . . . . . . . . . . . . . . . . 1-3

1.3.4 Characterization Data . . . . . . . . . . . . . . . . 1-3

1.3.5 Hazardous Waste Components . . . . . . . . . . . . . . . 1-3

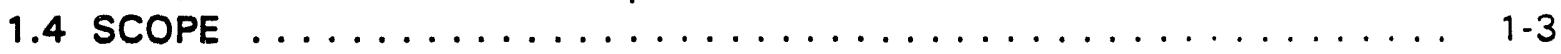

2.0 DESCRIPTION OF THE BABCOCK AND WILCOX'S PARK TOWNSHIP SITE

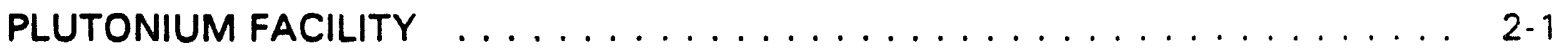

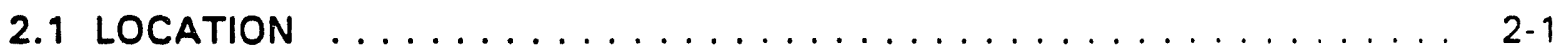

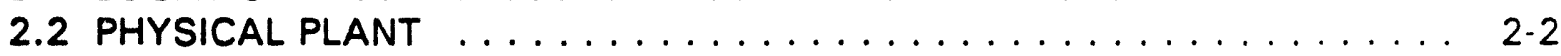

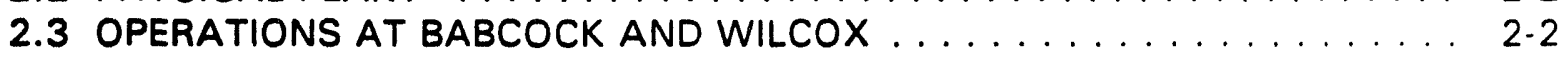

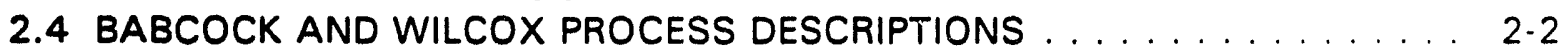

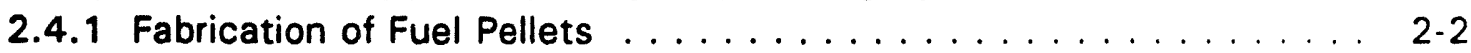

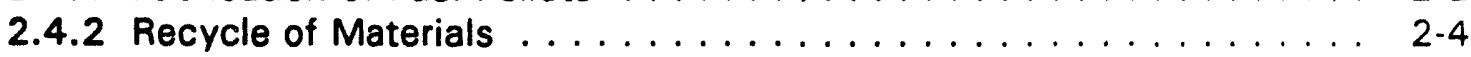

2.4.3 Scrap Recovery ... . . . . . . . . . . . . . . . . . . 2.4

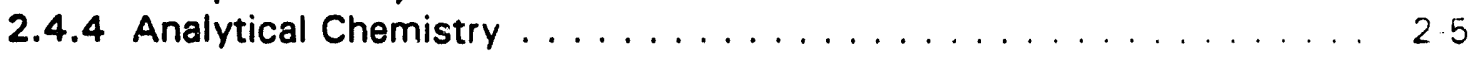

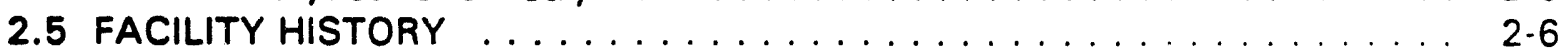

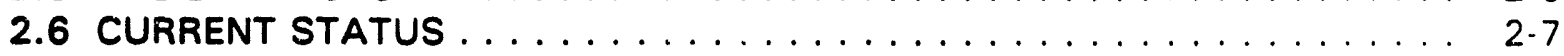

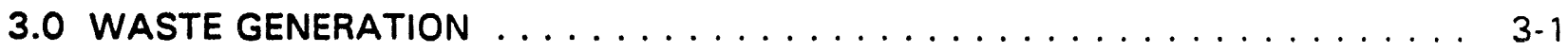

3.1 TRANSURANIC WASTE GENERATED BY THE FABRICATION OF MIXED-OXIDE

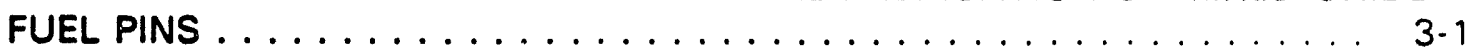

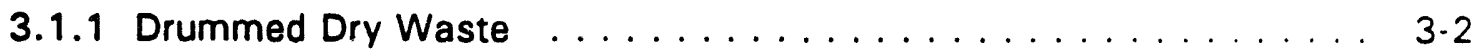

3.1 .2 Crated Dry Waste . . . . . . . . . . . . . . . . 3.3

3.1.3 Drummed Liquid Waste . . . . . . . . . . . . . . . . . . 3-4

3.2 TRANSURANIC WASTE GENERATED DURING DECONTAMINATION AND

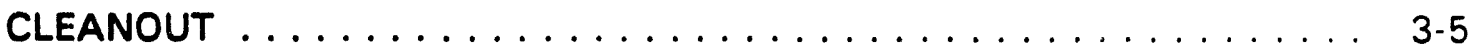

3.3 LOW-SPECIFIC-ACTIVITY WASTE GENERATED AT BABCOCK AND

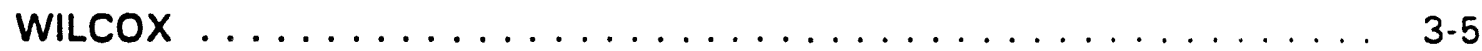

4.0 SOLID WASTE HANDLING PRACTICES AND PROCEDURES $\ldots \ldots \ldots \ldots \ldots$

4.1 HANDLING AND PACKAGING OF FUEL PIN FABRICATION WASTE . . . . . 4-1

4.1.1 Handling and Packaging of Drummed Dry Waste . . . . . . . . . . 4-1

4.1.2 Crated Dry Waste ... . . . . . . . . . . . . . . . . . . . . 4.2

4.1.3 Drummed Liquid Wastes .................... 4.2

4.2 HANDLING AND PACKAGING OF TRANSURANIC DECONTAMINATION AND

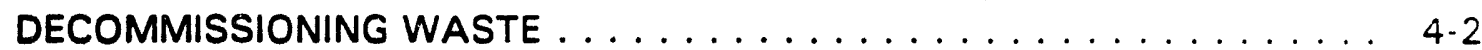

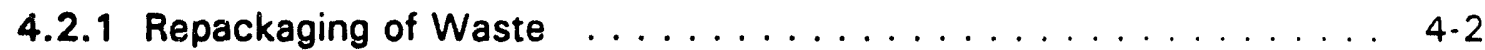

4.2.2 Gloveboxes and Special Equipment . . . . . . . . . . . . . . . 4-3 
CONTENTS (cont)

4.3 WASTE PACKAGING AND HANDLING REQUIREMENTS AT THE HANFORD SITE

5.0 CHARACTERIZATION OF RETRIEVABLY STORED SOLID WASTE GENERATED

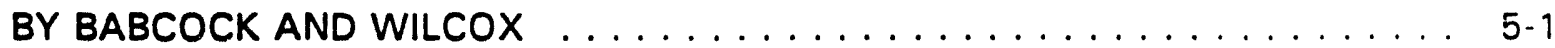

5.1 SUMMARY OF BABCOCK AND WILCOX WASTE GENERATION . . . . . 5- 5-1

5.1 .1 Waste Stored in $55-$ Gallon Steel Drums . . . . . . . . . . . . . . 5-2

5.1.2 Waste Stored in Containers Other Than 55-Gallon Steel Drums ... 5 5-3

5.1.3 Summary of Waste Generation Rates at Babcock and Wilcox . . . . 5.3

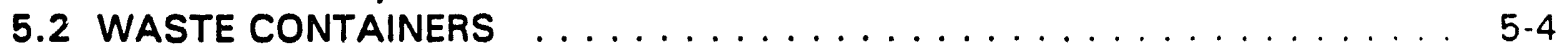

5.3 TRANSURANIC WASTE STORAGE LOCATIONS $\ldots \ldots \ldots \ldots \ldots \ldots \ldots . \ldots$

5.4 PHYSICAL CONTENTS OF TRANSURANIC WASTE CONTAINERS $\ldots \ldots \ldots$

5.5 RADIOLOGICAL DESCRIPTION OF BABCOCK AND WILCOX SOLID

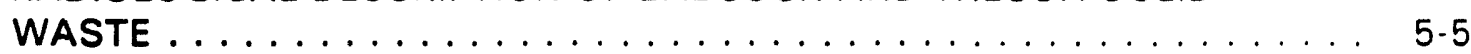

5.6 RADIOACTIVE ISOTOPES PRESENT IN BABCOCK AND WILCOX SOLID

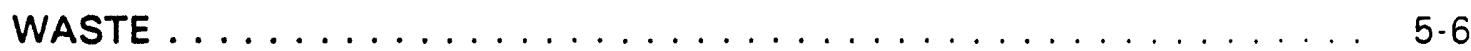

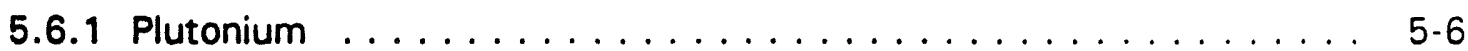

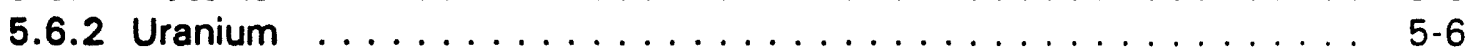

5.6.3 Americium . . . . . . . . . . . . . . . . . . . 5.6

5.7 HAZARDOUS CONSTITUENTS OF SOLID WASTE GENERATED BY BABCOCK

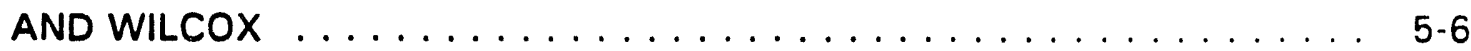

5.7.1 Solid Waste Information and Tracking System . . . . . . . . . . . . 5-6

5.7 .2 Burial Records ... . . . . . . . . . . . . . . . . . . 5 5-7

5.7.3 Interviews with Babcock and Wilcox Facility Personnel . . . . . . . 5.7

5.7.4 Hazardous Constituent Used in Babcock and Wilcox Facility

Process ........................... 5-7

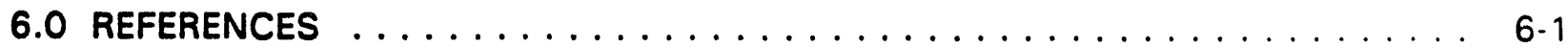


CONTENTS (cont)

APPENDIXES:

A DATA ON BABCOCK AND WILCOX WASTE GENERATION FROM THE SOLID WASTE INFORMATION TRACKING SYSTEM . . . . . . . . . . . A-1

A.1 CONTAINER NUMBER AND WEIGHT OF TRANSURANIC WASTE IN FIFTY-FIVE-GALLON DRUMS BY WASTE TYPE . . . . . . . . . A A.1-1

A.2 BABCOCK AND WILCOX TRANSURANIC WASTE CONTAINERS SORTED BY CONTAINER DESCRIPTION, SIZE, YEAR, AND PRIMARY WASTE TYPE

A.3 RADIOLOGICAL DATA FOR TRANSURANIC WASTE CONTAINERS SORTED BY DATE, PRIMARY WASTE TYPE, AND STORAGE FACILITY

A.4 PHYSICAL CONTENTS DESCRIPTION FOR BABCOCK AND WILCOX FIFTY-FIVE-GALLON DRUMS CONTAINING TRANSURANIC WASTE SORTED BY DATE, PRIMARY WASTE TYPE, AND STORAGE FACILITY

A.5 PHYSICAL CONTENTS DESCRIPTION FOR BABCOCK AND WILCOX TRANSURANIC WASTE CONTAINERS OTHER THAN FIFTY-FIVE-GALLON DRUMS SORTED BY DATE, PRIMARY WASTE TYPE, AND STORAGE

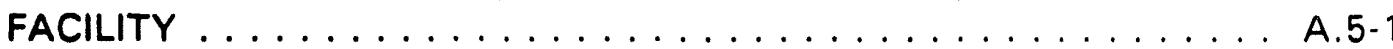

A.6 HAZARDOUS CONSTITUENTS OF FIFTY-FIVE-GALLON DRUMS CONTAINING TRANSURANIC WASTE

A.7 HAZARDOUS CUNSTITUENTS OF TRANSURANIC WASTE CONTAINERS

OTHER THAN FIFTY-FIVE-GALLON DRUMS

A.8 ISOTOPES LISTED IN FIFTY-FIVE-GALLON DRUMS CONTAINING TRANSURANIC WASTES

A.9 ISOTOPES LISTED IN TRANSURANIC CONTAINERS OTHER THAN FIFTY-FIVE-GALLON DRUMS 
WHC-EP-0719

This page intentionally left blank. 
WHC-EP-0719

\section{LIST OF FIGURES}

2-1 Layout of the Babcock and Wilcox Facility $\ldots \ldots \ldots \ldots \ldots$

2-2 Diagram of Fuel Fabrication Process $\ldots \ldots \ldots \ldots \ldots \ldots \ldots \ldots$

2-3 Plutonium Scrap Recovery Process . . . . . . . . . . . . . . 2-10

3-1 Volumetric Distribution of Constituents in Generated Line Wastes from the Production of Fuel Pins for Cores 1 and $2 \ldots \ldots \ldots \ldots$

3-2 Plutoniu.n Distribution Among Constituents of Lines Wastes Generated . . . . 3-7

4-1 Plutonium Facility Materials Control and Accountability Burial Shipment Checklist .......................... 4-6

4-2 Plutonium Facility Materials Control Box or Drum Checklist . . . . . . . . . 4-7

4-3 Burial Shipment Checklist $\ldots \ldots \ldots \ldots \ldots \ldots \ldots \ldots \ldots \ldots \ldots \ldots$

5-1 Number of Transuranic Fifty-Five-Gallon Drums Shipped to the Hanford Site by Babcock and Wilcox by Year ....................... 5-9

5-2 Weight of Transuranic Fifty-Five-Gallon Drums Shipped to the Hanford Site by Babcock and Wilcox by Year ..................... 5-10

5-3 Volume of Transuranic Fifty-Five-Gallon Drums Shipped to the Hanford Site by Babcock and Wilcox by Year ....................... 5-11

5-4 Number of Transuranic Other Containers Shipped to the Hanford Site by Babcock and Wilcox by Year ......................... 5.12

5-5 Weight of Transuranic Other Containers Shipped to the Hanford Site by

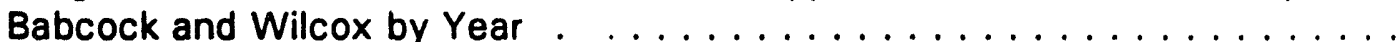

5-6 Volume of Transuranic Other Containers Shipped to the Hanford Site by Babcock and Wilcox by Yea

5-7 Total Number of Transuranic Waste Containers Shipped to the Hanford Site by Babcock and Wilcox by Yea

5-8 Total Weight of Transuranic Waste Containers Shipped to the Hanford Site by Babcock and Wilcox by Year ....................

5-9 Total Volume of Transuranic Waste Containers Shipped to the Hanford Site by Babcock and Wilcox by Year 
WHC-EP-0719

\section{LIST OF FIGURES (cont)}

5-10 Metal Box Storage on Asphalt Pad Transuranic Retrievable Storage Burial Ground 4C 200 West Area . . . . . . . . . . . . . . . . . . . . . 5-18

5-11 Grams of Transuranic Shipped to the Hanford Site $\ldots \ldots \ldots \ldots \ldots \ldots$ 


\section{LIST OF TABLES}

2-1 Gloveboxes and Hoods in Each Fabrication Area . . . . . . . . . . . . . 2-11

3-1 Volume and Disposition of Cores 1 and 2 Generated Wastes . . . . . . . . 3-8

3-2 Plutonium Concentration in Wastes Generated by Cores 1 and 2 Work, $\mathrm{g} / \mathrm{m}^{3}$. . 3-9

3-3 Cores 1 and 2 Waste Shipped to Retrievable Storage, $\mathrm{m}^{3}$, and Incremental Percent $(\%)$ of Pu Loss $(X . X X) \ldots \ldots$. . . . . . . . . . . . . . . . . . .

3-4 Scrap and Combined Waste Constituents for Drummed Dry Waste Generated During Cores 1 and 2 Work .................... $3-11$

3-5 Average Composition of Analytical Laboratory Liquid Wastes from Cores 1 and 2

3-6 Transuranic Waste Shipments to Richland, Washington . . . . . . . . . 3-13

4-1 Transuranic Storage Requirements for the Hanford Site . . . . . . . . . . . . 4-9

5-1 Transuranic Waste Generated at Babcock and Wilcox by Container Type and Year ................................. 5-20

5-2 Babcock and Wilcox Waste Summary Data for Fifty-Five-Gallon Drums $\ldots \ldots$ 5-22

5-3 Babcock and Wilcox Waste Summary Data for Containers Other Than

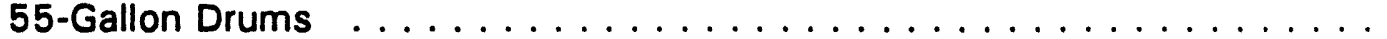

5-4 Babcock and Wilcox Transuranic Waste in Fifty-Five-Gallon Drums--Drum Count by Storage Location . . . . . . . . . . . . . . . . . . . . . . 5-24

5-5 Babcock and Wilcox Transuranic Waste in Containers Other Than Fifty-Five-Gallon Drums--Container Count by Storage Location .

5-6 Distribution and Percentage of Transuranic Fifty-Five-Gallon Drum Physical Contents by Storage Location--218-W-4C

5-7 Distribution and Percentage of Transuranic Containers Other Than Fifty-Five-Gallon Drum Physical Contents by Storage Location--218-W-4C . . 5-26

5-8 Babcock and Wilcox Transuranic Waste in Fifty-Five-Gallon Drums--Total Grams Transuranic by Storage Location . . . . . . . . . . . . . . . . .

5-9 Babcock and Wilcox Transuranic Waste in Containers Other Than Fifty-Five-Gallon Drums--Total Grams Transuranic by Storage Location 


\section{LIST OF TABLES (cont)}

5-10 Fifty-Five-Gallon Drum Waste from Babcock and Wilcox Containing Greater than 175 Grams Transuranic . . . . . . . . . . . . . . . . . . . . .

5-11 Other Container Waste from Babcock and Wilcox Containing Greater than 175 Grams Transuranic

5-12 Summary of Information from Solid Waste Storage Disposal Records for TRU Wastes with Hazardous Contents from Babcock and Wilcox . . . . . . . . . . . . 


\section{LIST OF TERMS}

AEC

ARCO

$D \& D$

DOE

DOT

Ecology

EPA

FFTF

HEDL

HEPA

$I A D$

LLW

LSA

MW

NRC

NUMEC

$O / M$

PVC

R-SWIMS

R\&D

RCRA

SDAR

SR

SWBR

SWITS

SWSDR

TRU

VAT

Westinghouse Hanford

WIPP

WRAP
Atomic Energy Commission

Atlantic Richfield Company

Decontamination and Decommissioning

U. S. Department of Energy

U. S. Department of Transportation

Washington State Department of Ecology

U. S. Environmental Protection Agency

Fast Flux Test Facility

Hanford Engineering Development Laboratory

High Efficiency Particulate Air Filter

Immediate Action Directive

low-level waste

low specific activity

mixed waste

Nuclear Regulatory Commission

Nuclear Materials and Equipment Corporation

oxygen-to-metal

polyvinyl chloride

Richland Solid Waste Information Management System

research and development

Resource Conservation and Recovery Act of 1976

Storage/Disposal Approval Record

scrap recovery

Solid Waste Burial Record

Solid Waste Information and Tracking System

Solid Waste Storage and Disposal Record

transuranic

valence adjustment tanks

Westinghouse Hanford Company

Waste Isolation Pilot Plant

Waste Receiving and Processing Facility 
WHC-EP-0719

This page intentionally left blank. 


\subsection{INTRODUCTION}

\subsection{PURPOSE}

The purpose of this report is to characterize, as far as possible, the solid radioactive wastes generated by Babcock and Wilcox's Park Township Plutonium Facility near Leechburg, Pennsylvania that were sent to retrievable storage at the Hanford Site. Solid waste as defined in this document is any containerized or self-contained material that has been declared waste. The objective is a description of characteristics of solid wastes that are or will be managed by the Restoration and Upgrades Program; gaseous or liquid effluents are discussed only at a summary level. This characterization is of particular interest in the planning of transuranic (TRU) waste retrieval operations, including the Waste Receiving and Processing (WRAP) Facility, because Babcock and Wilcox generated greater than $\mathbf{2 . 5}$ percent of the total volume of TRU waste currently stored at the Hanford Site.

\subsection{BACKGROUND}

Since 1944, th a production of defense-related materials at the Hanford Site and other offsite locations has generated radioactive wastes. The bulk of these wastes have been disposed of or stored in the 200 East and 200 West Areas burial grounds and waste storage facilities.

Between 1944 and 1970, both TRU and low-level wastes (LLW) were disposed of in shallow land trenches, with no attempt to segregate these materials by their chemical or radioactive natures. In 1970, the Atomic Energy Commission ([AEC], now the U.S. Department of Energy [DOE]), directed that AEC sites segregate "waste with known or detectable contamination of transuranium nuclides" from other waste types [/mmediate Action Directive 0511-21 (Appendix A in Duncan 1991)]. Transuranic radionuclides are those with an atomic number greater than 92. The AEC further directed that these wastes be packaged and stored as contamination-free packages for at least 20 years. The 20 -year interim storage period was to allow time to study permanent disposal options for TRU contaminated wastes.

The Immediate Action Directive (IAD) did not provide a detailed definition for TRU waste in 1970. AEC contractors implemented the IAD to the best of their ability with the instrumentation then available. In 1973, the Atomic Energy Commission Manual (AEC 1973) further defined TRU waste as material contaminated with certain alpha-emitting radionuclides with half-lives greater than 20 years, and activity greater than $10 \mathrm{nCi} / \mathrm{g}$. The radionuclides included were ${ }^{233} \mathrm{U}$ and its daughter products as well as $\mathrm{Pu}$ and transplutonium nuclides, with the exception of ${ }^{230} \mathrm{Pu}$ and ${ }^{241} \mathrm{Pu}$. In 1982, the TRU waste segregation limits were raised to $100 \mathrm{nCi} / \mathrm{g}$, including ${ }^{230} \mathrm{Pu}$ and ${ }^{241} \mathrm{Pu}$, as stated in DOE Order 5820.1, Management of Transuranic Material (DOE 1982).

In addition to radioactive materials, a wide variety of chemicals can be found in the solid wastes that are stored or disposed of at the Hanford Site. Many of these chemicals currently are classified as dangerous or hazardous by the U. S. Environmental Protection 
Agency (EPA) and the Washington State Department of Ecology (Ecology). When dangerous or hazardous wastes are found in radioactive wastes, they are termed mixed wastes (MW).

When much of the MW now located at the Hanford Site was generated, there were no definitions or regulations governing the storage, disposal, or documentation of MW. In 1987, DOE issued a mixed byproduct ruling (52 FR 15937) stating that the hazardous components of mixed waste are regulated by the Resource Conservation and Recovery Act of 1976 (RCRA). In November 1987. EPA authorized Ecology to regulate the hazardous constituents of MW at the Hanford Site (40 CFR 265).

During the next two decades the TRU waste now stored in the burial trenches and storage facilities is to be retrieved, processed at the WRAP Facility, and shipped to the Waste Isolation Pilot Plant (WIPP) near Carlsbad, New Mexico for final disposal. Approximately 2.5 percent of the total volume of TRU waste to be retrieved for shipment to WIPP was generated by Babcock and Wilcox and transported to the Hanford Site for interim storage.

\subsection{SOURCES}

Data for this study were compiled from a variety of sources. Each of the major sources is listed below with a few explanatory notes. Greater detail on each of the data sources can be found in the body of this document as the information from each is discussed.

\subsubsection{Documents That Describe Pertinent NUMEC and Babcock and Wilcox Processes}

Documents that describe pertinent Babcock and Wilcox processes, including the Waste Generated During Fabrication of Mixed Oxide Nuclear Fuels (Bradley and Clark 1978) and Technical Data Summary Report on Decontamination and Removal of Equipment in the Parks Township Site Plutonium Facility (Babcock and Wilcox 1983) were used to determine the solid wastes that were generated at Babcock and Wilcox and sent for storage at the Hanford Site.

\subsubsection{Documents That Describe Babcock and Wilcox Waste Packaging and Handling Procedures}

Documents that describe Babcock and Wilcox Waste Packaging and Handling Procedures, including the Hanford Site Radioactive Solid Waste Acceptance Criteria (Willis and Triner 1990), were used to describe packaging and handling practices. 


\subsubsection{Interviews}

Interviews with former Babcock and Wilcox personnel at the Parks Township, PA site were used to gather information regarding unusual waste contents and historical waste-handling and packaging procedures.

\subsubsection{Characterization Data}

Characterization data were primarily derived from the Solid Waste Information and Tracking System (SWITS) database. The SWITS database was created in 1991, primarily with the solid waste data from the Richland Solid Waste Information Management System (R-SWIMS). The SWITS database contains information about radioactive wastes, both TRU and LLW, buried or stored in the 200 Areas since 1970. Data in SWITS were originally taken from Solid Waste Burial Records (SWBR) and their replacements, the Solid Waste Storage and Disposal Records (SWSDR). Both SWBRs and SWSDRs, which will be jointly referred to as 'burial records' in this document, often contain supplementary forms such as shipment manifests, Nuclear Regulatory Commission (NRC) 741 Forms, etc.

\subsubsection{Hazardous Waste Components}

Hazardous waste components were determined using information from the SWITS database, SWBRs, SWSDRs, and personnel interviews. Additional information was obtained from Unstable and Reactive Chemicals in Transuranic Retrievable Waste at the Hanford Site, WHC-EP-0603 (Reddinger 1992) and an internal report examining hazardous components of solid waste.

\subsection{SCOPE}

The major sections of this document and the topics they cover are outlined briefly below. Because of the number of tables and figures included in this report, they appear at the end of each section.

Section 2.0 provides a brief description of the NUMEC and Babcock and Wilcox physical plant and the operations that occurred there. A short history of the significant Babcock and Wilcox operations that generated the solid wastes transported to the Hanford Site for storage follows this description.

Section 3.0 identifies the Solid Waste Streams that arose from pertinent Babcock and Wilcox activities. The types and amounts of solid waste that may have been generated from each waste stream are estimated.

Section 4.0 discusses the waste-handling and packaging procedures used for Babcock and Wilcox wastes shipped to the Hanford Site. Historical changes in waste handling, packaging, and recordkeeping also are reviewed in this section. 
Section 5.0 contains the results of a search for actual waste container data. The search included database searches, literature review, and personnel interviews. This section describes what is known about the physical, radiological, and hazardous characteristics of the radioactive solid waste from Babcock and Wilcox.

Section 6.0 lists the references used in this report. 


\subsection{DESCRIPTION OF THE BABCOCK AND WILCOX'S PARK TOWNSHIP SITE PLUTONIUM FACILITY}

The Parks Township Site Plutonium Facility began operations in 1960, when it was owned and operated by Nuclear Materials and Equipment Corporation (NUMEC). In April 1967, NUMEC became a wholly owned subsidiary of the Atlantic Richfield Company (ARCO) which sold the company to Babcock and Wilcox in November 1971. Babcock and Wilcox merged NUMEC into itself in late 1974. In many of the documents dating back to the mid- to late-1970's, the NUMEC name is used instead of, or in addition to, Babcock and Wilcox.

The wastes that were sent to the Hanford Site from the Plutonium Facility were generated during the fabrication of $\mathrm{PuO}_{2}-\mathrm{UO}_{2}$ fuel rods and pellet stacks for the Fast Flux Test Facility (FFTF) and the subsequent decontamination a: 'leanout activities. The FFTF, the first step in the Liquid Metal Breeder Reactor Prob am, is a sodium-cooled experimental breeder reactor located at the Hanford Site in Washington State. The Parks Township Plutonium Facility fabricated some of the fuel pins for cores 1 and 2 (Kerr-McGee, Crescent, Oklahoma, provided the rest) and all of the fuel pins for cores 3 and 4.

Some of the TRU wastes generated at the Parks Township site were sent to the Hanford Site for Pu scrap recovery, while the remainder of the TRU waste was placed in retrievable storage. Transuranic wastes were generated by NUMEC as early as 1972; however, the waste designated in the SWITS database does not list Babcock and Wilcox as a generator until 1981. The wastes shipped to the Hanford Site before 1981 often were redesignated as coming from the onsite facility where the waste had been received or assayed. In some cases, particularly waste generated before 1977, it may not be possible to accurately determine where waste shipped from Babcock and Wilcox can be found in the 200 Areas burial grounds. Alternately, waste may have been shipped to the commercial nuclear waste disposal facility at the Hanford Site (now operateo by U.S. Ecology). There is documentation for waste shipments in 1974 to 1979 from NUMEC and Babcock and Wilcox to the commercial waste disposal facility, but records are incomplete.

\subsection{LOCATION}

fiabcock and Wilcox's former Plutonium Facility is situated on a 69 acre tract located in Parks Township at the southwestern edge of Armstrong County in southwestern Pennsylvania. The site is on Pennsylvania State Highway Route 66, North, between Leechburg and North Vandergrift, near the intersection with Kiskimere Road. It is bordered on the northwest by the Kiskiminetas River. The town of North Vandergrift is 1.8 miles southeast of the site. Pittsburgh is 23 air miles to the southwest.

The Parks Township site is located in one of the narrow valleys characteristic of the Appalachian Plateau Province. The site area is a narrow, relatively flat river plain surrounded by rolling ridges. The highest land point near the site is a 122 -meter(400-foot-) high ridge approxirnately $1.6 \mathrm{~km}$ (1 mile) east. 


\subsection{PHYSICAL PLANT}

The Babcock and Wilcox Parks Township Site Plutonium Facility is a three-story building of approximately $6,975 \mathrm{~m}^{2}\left(75,000 \mathrm{ft}^{2}\right)$. The facility consists of nine fabrication areas, a hot cell, and administrative office areas. Additionally, the facility contains two sintering furnaces; numerous smaller conversion, presintering, drying, vacuumoutgassing and oxidation/reduction muffle-type furnaces; and analytical laboratory equipment and apparatus. Figure 2-1 provides a layout of the Babcock and Wilcox Facility.

The plant contained approximately 95 gloveboxes and hoods used to support the activities listed below in Section 2.3. Table 2-1 lists the number of gloveboxes and hoods in each fabrication area and provides a general description of their use. The gloveboxes and hoods shown include both TRU and non-TRU contaminated enclosures. This table also provides approximate sizes of each fabrication area (Babcock and Wilcox 1983).

\subsection{OPERATIONS AT BABCOCK AND WILCOX}

The activities performed at Babcock and Wilcox during the period when the waste sent to the Hanford Site was generated included the following:

- Manufacture of fuel for the FFTF

- Scrap recovery and conversion of $\mathrm{Pu}\left(\mathrm{NO}_{3}\right)_{0}$ to $\mathrm{PuO}_{2}$

- Analytical and quality control operations

- Research and development (R\&D) activities

- Handling of radioactive by-product source materials

- Fuel storage and shipping.

\subsection{BABCOCK AND WILCOX PROCESS DESCRIPTIONS}

The various processes involved in the fabrication of mixed-oxide fuel, which resulted in the generation of wastes that were sent to the Hanford Site, are described in this section.

\subsubsection{Fabrication of Fuel Pellets}

A flow diagram of the fuel fabrication process used at Babcock and Wilcox is shown in Figure 2-2. All line operations were performed in the controlled glovebox containments. The usual bag-in and bag-out operations were used to introduce working materials into the glovebox line and to remove finished products, wastes, etc. Linegenerated wastes were bagged out in approximately 6-L (1.6-gal) paper cartons that were assayed individually with a lithium-drifted germanium (GeLi) counting system and packaged in 55-gal steel drums (21 cartons per drum).

$\mathrm{PuO}_{2}$ was received from offsite suppliers in sealed cans. The $\mathrm{PuO}_{2}$ was stored until it could be introduced to the process area where it was weighed, randomly sampled, and analyzed. The $\mathrm{PuO}_{2}$ was calcined in a dry-air atmosphere at $825^{\circ} \mathrm{C}$ for one hour, 
ballmilled at $70 \mathrm{rpm}$ with approximately $1.3-\mathrm{cm}(.5-\mathrm{in.})$ tungsten carbide balls, sieved through a 170 mesh screen, and then blended in a liquid-solids V-blender. Blended 20-kg (44-lb) lots were used for subsequent processing.

The blended $\mathrm{PuO}_{2}$ powder was mixed with $\mathrm{UO}_{2}$ obtained from natural $U$ ore or from depleted $U$ stock having an isotopic composition of less than 0.3 percent ${ }^{235} \mathrm{U}$. This mixture plus recycled mixed-oxide powder, if added, was blended in a liquid-solids model V-blender using a three-stage blending cycle. The blended batch was fed by a belt feeder into a fluid-energy jet mill for additional blending to ensure microhomogeneity. After jet milling, the mixed-oxide powder was sieved through 60-mesh screens, then was lot-blended in a V-blender.

A burnable organic binder was added to the mixed-oxide lot for controlling the density of the sintered pellets. A V-blender was used to blend the organic binder and mixed-oxide powder that were then slugged or compacted in a 20-ton, single-punch automatic press to a nominal density of $\mathbf{4 5}$ percert of theoretical. The slugs were broken mechanically into dense particles by treatment, in a coarse and then a fine granulator, respectively, and the granules screened into -20-mesh size fractions. The granules in these fractions were V-blended with Sterotex ${ }^{*}$ or Carbowax ${ }^{*}$ die lubricant and, using a dual-cavity compacting press, were pressed into cylindrical pellets with a density of 55 to 60 percent of theoretical.

A presintering procedure was used to reduce the oxygen-to-metal ratio of the fuel and to destroy the organic additives. This operation consisted of presintering the pellets in a batch-type electric furnace at $850^{\circ} \mathrm{C}$ for 2 hours in a reducing gas mixture of Ar $-8 \% \mathrm{H}_{2}$. Next, the pellets were sintered in a continuous production-type electric furnace at 1500 to $1700{ }^{\circ} \mathrm{C}$ for 4 to 10 hours in the reducing atmosphere of $\mathrm{Ar}-8 \% \mathrm{H}_{2}$. Following this process the final oxygen to metal ratio was less than 1.940.

Any mixed-oxide pellets that were oversized were centerless ground to the correct diameter, $.4940 \pm .0038 \mathrm{~cm}(0.1945 \pm 0.0015 \mathrm{in.})$. Most of the centerless grinding was done under dry conditions, superseding the earlier operation, shown in Figure 2-2, in which wet grinding was followed by washing and drying steps.

The pellets were inspected and, if necessary, vacuum degassec at $750{ }^{\circ} \mathrm{C}$ for 2 hours. The certified pellets were loaded into fuel stacks and sealed in the fuel pins. The loaded fuel pins were decontaminated by making repeated wipes with cotton swabs and methyl alcohol (Bradley and Clark 1978).

\footnotetext{
'Sterotex is a trademark of Capital City Products Company.

". Carbowax is a trademark of Union Carbide Corporation.
} 


\subsubsection{Recycle of Materials}

The fuel fabrication line operations generated some clean, dry recyclable material that could be treated to obtain acceptable forms that were added to the mixed-oxide feed lots. Both sintered (hard) and unsintered (green) materials were processed through the recycle operation.

The recycled sintered powder and/or pellets were first screened through a 16-mesh screen. The +16 fraction was oxidized in air at $850^{\circ} \mathrm{C}$ for 2 hours and then reduced in Ar $-8 \% \mathrm{H}_{2}$ (or $\mathrm{N}_{2}-8 \% \mathrm{H}_{2}$ ) at $850^{\circ} \mathrm{C}$ for 1 hour. The material was screened again through a 16-mesh screen. The +16 -mesh material was either recycled through the oxidation/reduction stages or it was crushed and then recycled. The -16-mesh material from both before and after oxidation/reduction was ballmilled for 8 hours, then was screened through a 100-mesh screen. The +100 -mesh material was recycled through the ballmilling stage, while the -100-mesh material was used in the recycle powder blends prepared before jet milling (Figure 2-2).

Green recycle material was processed in the same manner as the hard material except that an additional organic removal step was required in the initial stage (Bradley and Clark 1978).

\subsubsection{Scrap Recovery}

The flow sheet for scrap recovery is shown in Figure 2-3. After assay, the assorted scrap materials were introduced into the scrap recovery receiving glovebox and placed in special 'charge bottles.' The scrap powder was charged into a geometrically safe dissolve and treated by refluxing with $10 \mathrm{M} \mathrm{HNO}_{3}$ containing $0.1 \% \mathrm{HF}$ for approximately 4 hours. After cooling and settling, the dissolver solutions were vacuum transferred through a filter to the valence adjustment tanks (VAT) in a second glovebox. A new preweighed scrap charge and fresh acids were introduced into the dissolver and the cycle was repeated until the residue (heel) in the dissolver vessel made filtration difficult or too time-consuming. At such time, a 'joil out' run was made using the same procedure except that no scrap powders were charged to the dissolver.

The dissolver solutions in the VAT were prepared for subsequent ion exchange operations by diluting them to about $6.5 \mathrm{M} \mathrm{HNO}$. Ferrous sulfamate and sodium nitrite were then added for Pu valence adjustment by first reducing Pu(VI) to Pu(IV)/Pu(III), and then oxidizing Pu(III) to Pu(IV). Thus adjusted, the VAT solutions were transferred through a polishing filter to ion exchange feed storage tanks. These solutions, containing $\mathrm{Pu}, \mathrm{U}$, and other metal nitrates along with small amounts of fluorides and sulfates, next were pumped through glass columns packed with Permutit ${ }^{*}$ SK or lonac ${ }^{*} 580$ anion exchange resin. In the concentrated $\mathrm{HNO}_{3}$ solution, Pu formed the anionic complex $\mathrm{Pu}\left(\mathrm{NO}_{3}\right)_{0}^{-2}$ which was absorbed strongly by the resin. Most of the metallic impurities in the $\mathrm{HNO}_{3}$ solution

\footnotetext{
'Permutit is a trademark of Permutit Company, Inc.

"Ionac is a trademark of Sybron Chemical Holding, Inc.
} 
did not form anionic complexes under these conditions and, consequently, were not absorbed by the resin. The Pu-loaded ion exchange column was washed with 7.2 $\mathrm{M} \mathrm{HNO}_{3}$ to ensure complete removal of the impurities and the $U$. Finally, Pu was eluted from the column using $0.6 \mathrm{M} \mathrm{HNO}$.

Treatment of the scrap recovery solutions by ion exchange was a cyclical process consisting of four operations:

1. Resin preconditioning operation

2. Pu-loading operation

3. Pu-wash operation

4. Pu-elution operation

The Pu-containing ion exchange eluant was pumped directly into the boiler section of a steam evaporator where the solution subsequently was concentrated by evaporation. The overheads (distillate) were collected and pumped to medium-level waste tanks for storage or reprocessing. Evaporator bottoms (concentrate) of $\mathrm{Pu}\left(\mathrm{NO}_{3}\right)_{6}$ solution were mixed, sampled, and vacuum transferred to 10-L (2.6-gal) plastic bottles or to the product storage tanks. As sufficient quantities were accumulated, the $\mathrm{Pu}\left(\mathrm{NO}_{3}\right)_{6}$ solution was returned as scrap recovery product to a $\mathrm{PuO}_{2}$ conversion facility.

\subsubsection{Analytical Chemistry}

Chemical analysis of selected samples was done routinely on each fuel lot for quality control to ensure that the fuel products met specified standards. The analytical program required continued sampling of the mixed-oxide powders and pellets and, consequently, generated additional TRU wastes.

The following procedures were used:

2.4.4.1 Carbon. The determination of the carbon in Pu oxides, $U$ oxides, U-Pu mixed oxides, metal, and alloys was done by combustion to $\mathrm{CO}_{2}$ followed by gas chromatographic measurements.

2.4.4.2 Chloride. Chloride was determined by photometric analysis after pyro-hydrolysis. The method was applied to the determination of residual chloride on the surface of fuel pin metal components (i.e., end caps, reflector pins, springs, plenum spacers, cladding tubes, and fuel pins).

2.4.4.3 Fluoride. The residual fluoride on the surface of the fuel pin metal components (i.e., end caps, reflector pins, springs, plenum spacers, cladding tubes, and fuel pins) was determined by extraction into a known volume of a hot solvent followed by a specific ion electrode procedure.

2.4.4.4 Gas Evolution. Gas was removed from sintered pellets by vacuum extraction at $1600^{\circ} \mathrm{C}$ and was analyzed by mass spectrometry. 
2.4.4.5 Moisture Analysis. Moisture content of the pellets was determined coulometrically in an electrolytic $\mathrm{P}_{2} \mathrm{O}_{5}$ cell.

2.4.4.6 Oxygen-to-Metal Ratio. The oxygen-to-metal ratio (O/M) was determined gravimetrically using a modified Lyons method involving oxidation of the sample in $\mathrm{O}_{2}$ at $850{ }^{\circ} \mathrm{C}$ followed by reduction in $\mathrm{Ar}-8 \% \mathrm{H}_{2}$ at $950{ }^{\circ} \mathrm{C}$. A proven equivalent procedure, the Chikalla method, also was used for O/M ratio determinations.

2.4.4.7 Phosphorus. Phosphorus was determined by the molybdenum blue photometric method. The method was applied to Pu and mixed-oxide powders.

2.4.4.8 Sulfur. The sulfur determination involved combustion of mixed oxide powders in Leco crucibles in a stream of $\mathrm{O}_{2}$ to form $\mathrm{SO}_{2}$, which then was titrated with potassium iodate.

2.4.4.9 Tungsten. The tungsten content of mixud oxide powders was determined spectrophotometrically as the dithiol complex, following separation from $U$ and $P u$ by liquid-liquid extraction. Later, tungsten content was determined by a mass spectrographic procedure using a $\mathrm{AgCl}$ carrier.

2.4.4.10 Rare Earths. The rare earths contained in mixed-oxide samples were determined by spectrographic analysis after separation from $U$ and $P u$ by solvent extraction.

2.4.4.11 Nitrogen. Two methods were available for nitrogen analysis: a carrier gas fusion extraction procedure for analysis of metals for the oxides and a Kjeldahlspectrophotometric procedure for mixed-oxide powders.

2.4.4.12 Isotopic Analysis. The isotopic compositions of PU and $U$ were determined by thermal emission mass spectrometry following the separation of Pu from Am and $U$ by anion-exchange purification.

2.4.4.13 Plutonium. Determination of the Pu content of Pu alloys, metal, nitrate, and oxides was accomplished by dissolving the sample (the oxide is dissolved in fuming $\left.\mathrm{H}_{2} \mathrm{SO}_{4}\right)$, oxidizing the $\mathrm{Pu}$ to the +6 state with $\mathrm{Ag}(\mathrm{II})(\mathrm{AgO})$, and titrating amperometrically with standard ferrous ammonium sulfate solution.

2.4.4.14 Uranium. Two methods were used for $U$ analysis as follow: a phosphoric acid reduction followed by amperometric titration using standardized potassium dichromate for $U$ fuel and process materials; and anion exchange separation and photometric method for $\mathrm{U}$ at concentrations between 300 and $3,000 \mathrm{ppm}$ in ceramic grade $\mathrm{PuO}_{2}$ and $\mathrm{Pu}$ nitrate solutions. A mass spectrographic analysis also was developed for the detection of trace amounts of $U$ in Pu materials (Bradley and Clark 1978).

\subsection{FACILITY HISTORY}

The waste sent to the Hanford Site by Babcock and Wilcox was generated during five distinct operation periods. Each of these periods is described briefly below. 
WHC-EP-0719

- Late CY 1972 to early CY 1973--Qualification testing on production of FFTF fuel pins.

- CY 1973 to CY 1975--Routine production of FFTF cores 1 and 2 and subsequent scrap recovery operations.

- CY 1975--Operations for equipment maintenance and general plant cleanout preparatory to start of FFTF cores 3 and 4 production.

- $\quad$ CY 1976 to CY 1979--Production of fuel pins for FFTF cores 3 and 4.

- CY 1980 to CY 1983--During March 1980, Babcock and Wilcox announced the phaseout of its Plutonium Facility operations and subsequently began the decontamination and removal of equipment in the facility. As of March $1983,368 \mathrm{~m}^{3}\left(13,000 \mathrm{ft}^{3}\right)$ of TRU waste generated by this cleanout were stored in burial grounds at the DOE's Hanford Site at Richland, Washington. Also, $1,212 \mathrm{~m}^{3}\left(42,800 \mathrm{ft}^{3}\right)$ of low-specific-activity waste were buried at other sites (Babcock and Wilcox 1983).

\subsection{CURRENT STATUS}

The Park Township facility currently is occupied by Nuclear Environmental Services Inc., a subsidiary of Babcock and Wilcox. The Babcock and Wilcox Parks Township Facility is managed and operated by B\&W Nuclear Environmental Services Inc., an affiliate of Babcock and Wilcox. 
Figure 2-1. Layout of the Babcock and Wilcox Facility.

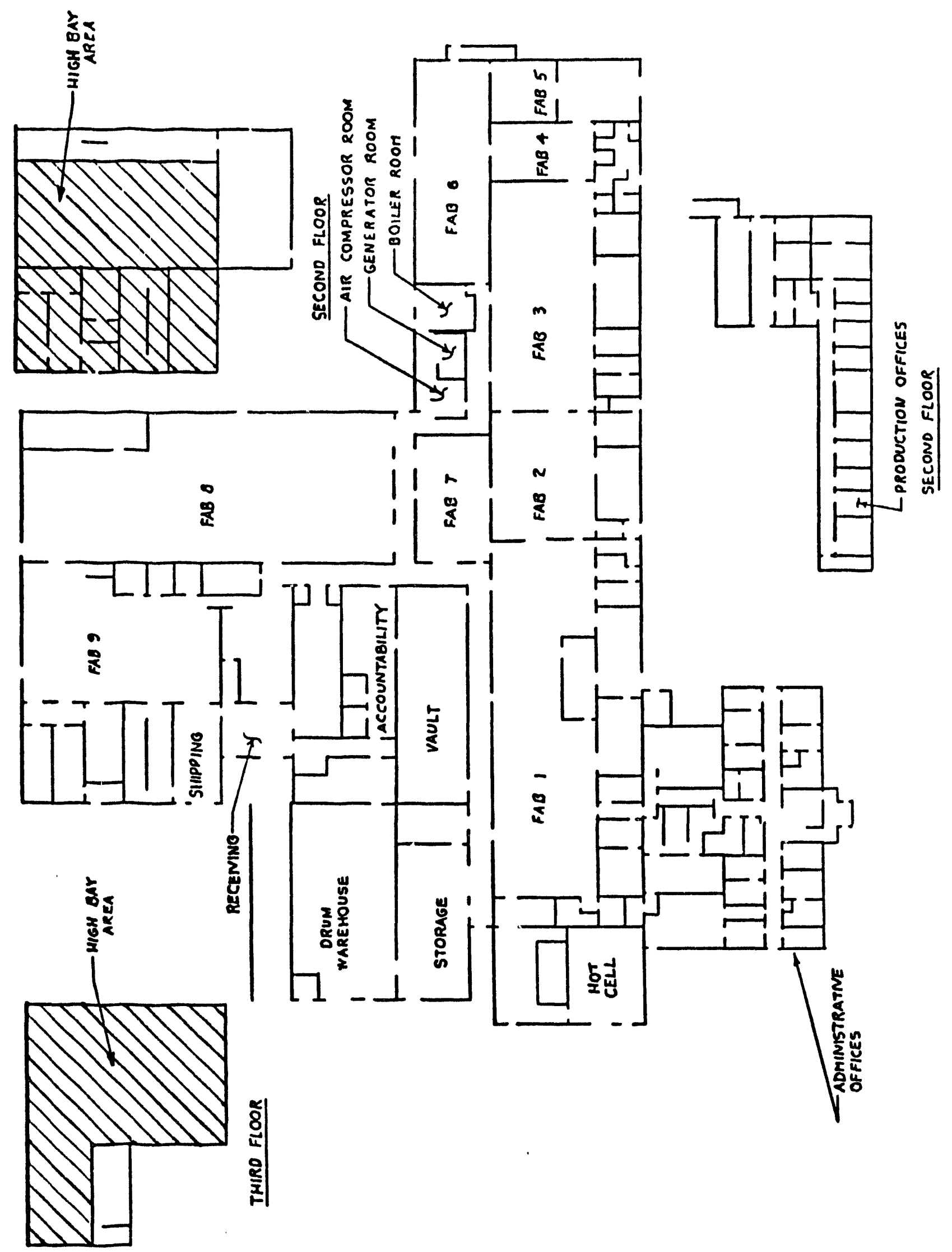


Figure 2-2. Diagram of Fuel Fabrication Process.

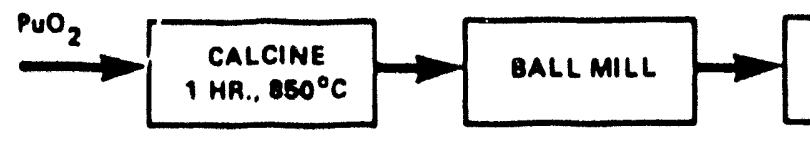

(1) SAMPLE for Pu ASSAY, IMPUAities.

POWDE R CHARACTERISTICS.

(2) DIMENSIONAL INSPECTION.

(3) SAMPLE FOR PU ASSAY, U ASSAY, TOR, OM, HzO. IMPUAITIES. ISOTOPIC, HOMOOENEITY, DIMENSIONS. DENSITY, VISUAL.

(A) WASH AND OAY WAS DISCONTINUED FOLLOWINO CHANGEOVEA TO DAY CENTE RLESS OAIND.I

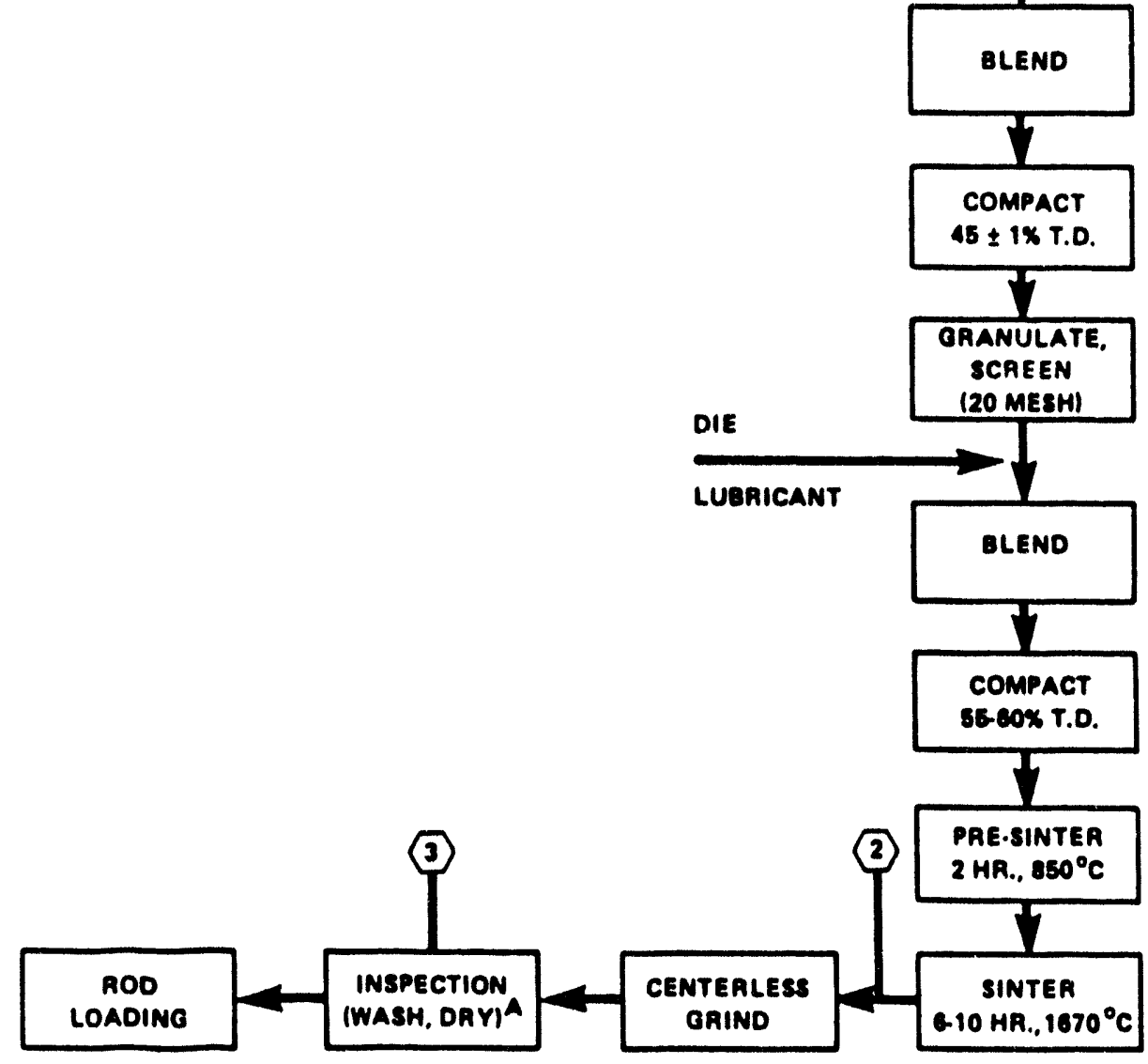




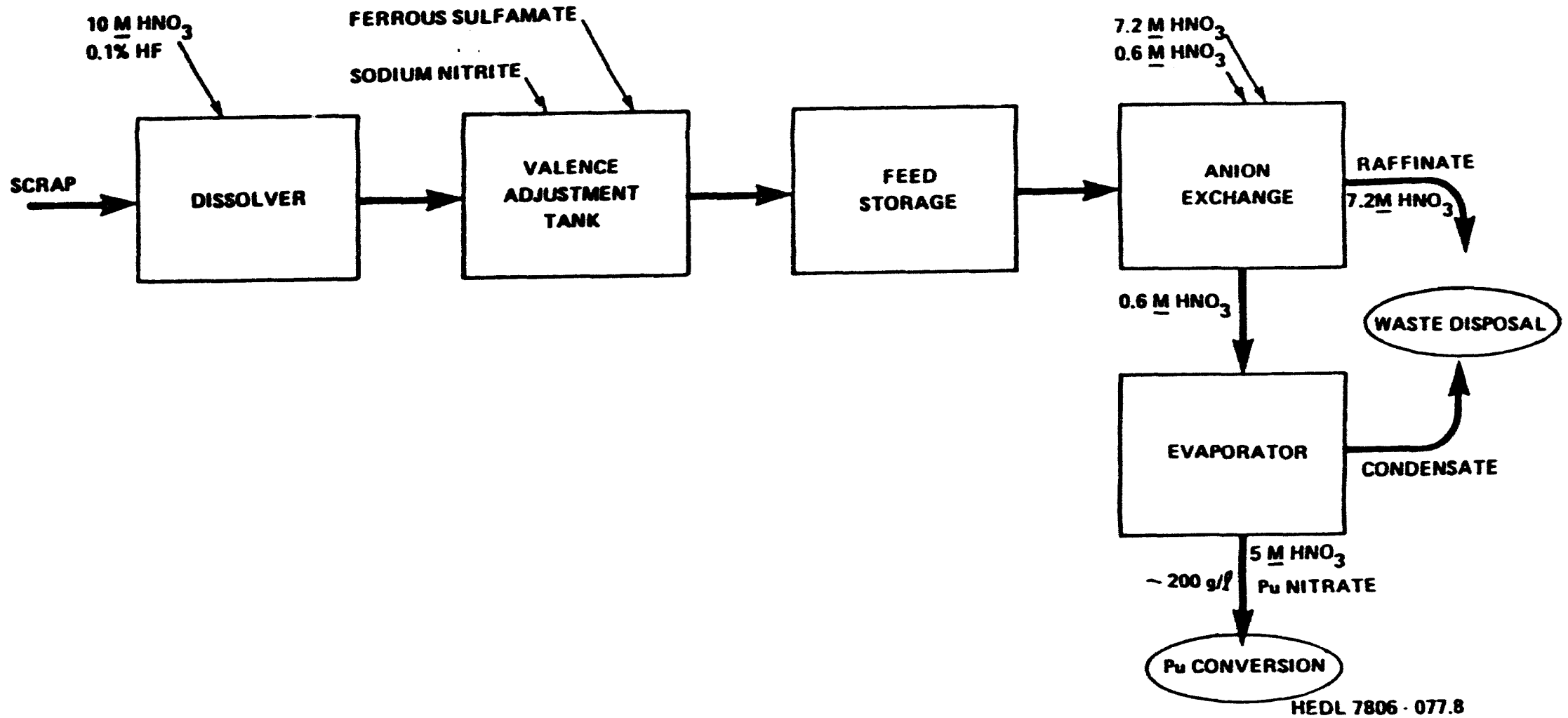

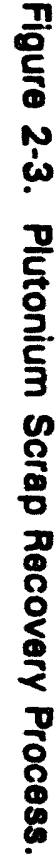

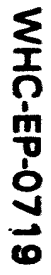

HEDL $7806 \cdot 077.8$ 


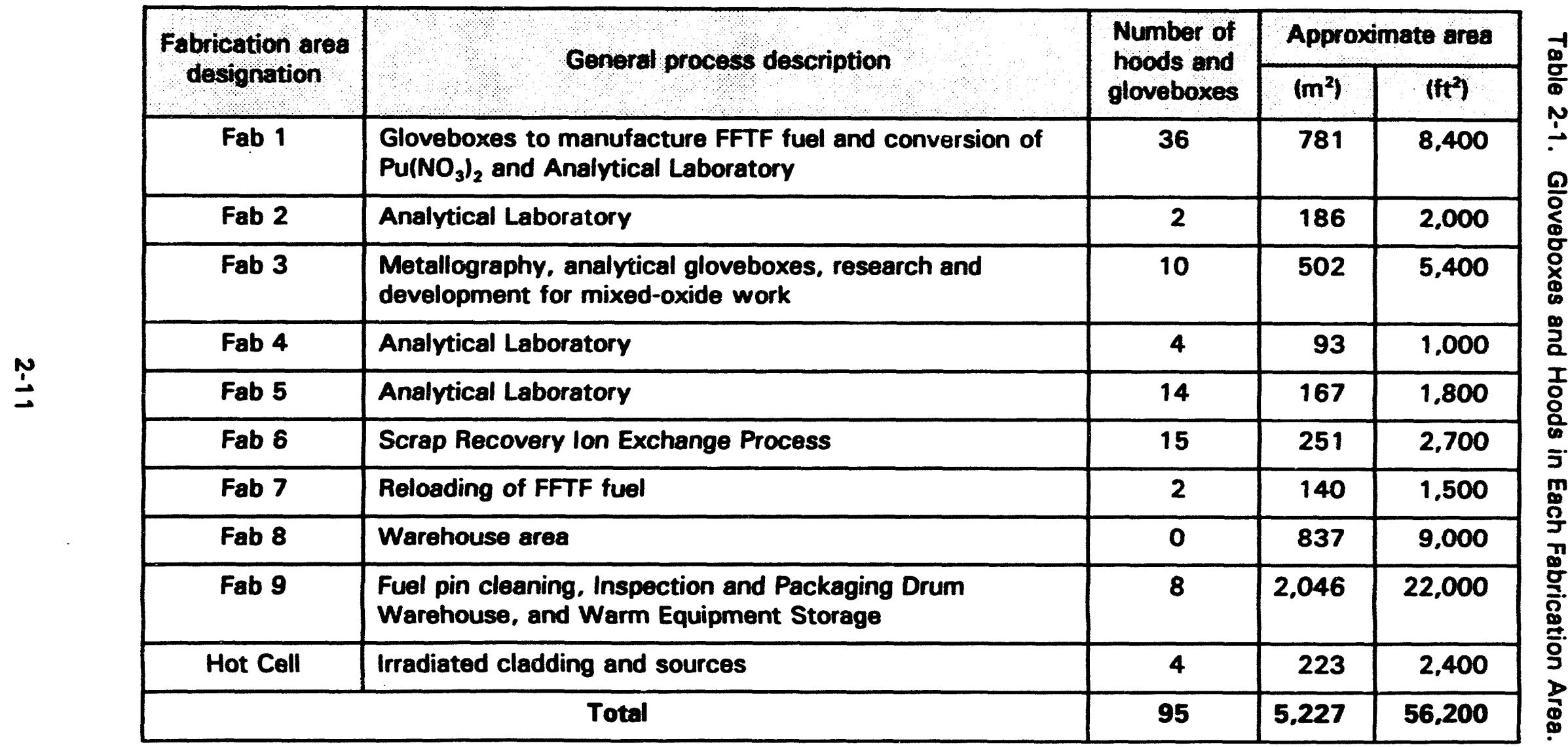


WHC-EP-0719

This page intentionally left blank.

2-12 


\subsection{WASTE GENERATION}

The TRU solid waste sent to the Hanford Site by Babcock and Wilcox during the 1970's and early 1980's was generated as the result of the following three activities:

- Fabrication of FFTF fuel pins for cores 1 and 2 and subsequent scrap recovery operations

- Fabrication of FFTF fuel pins for cores 3 and 4

- Decontamination and cleanout of the Plutonium Facility Operations.

The waste created by the first activity has been described in detail in a report issued by the Hanford Engineering Development Laboratory (HEDL) (Bradley and Clark 1978). Because there is no comparable document for the fabrication of FFTF fuel pins for cores 3 and 4, it has been assumed that the waste generated by the fabrication of fuel pins for FFTF cores 3 and 4 is not substantially different from that generated during fuel pin fabrication for cores 1 and 2. The third activity, decontamination and cleanout of the Plutonium Facility, has been detailed in a technical summary report submitted by Babcock and Wilcox to Westinghouse Hanford Company (Westinghouse Hanford) (formerly HEDL) (Babcock and Wilcox 1983).

The material found in this section, "Waste Generation," and Section 4.0, "Solid Waste Handling Practices and Procedures," is based on material found in the references listed above and interviews with Babcock and Wilcox personnel.

\subsection{TRANSURANIC WASTE GENERATED BY THE FABRICATION OF MIXED-OXIDE FUEL PINS}

The various processes involved in the production of mixed-oxide fuel that resulted in the generation of TRU wastes are listed below:

- Fabrication of fuel pellets

- Recycle of materials

- Scrap recovery

- Analytical chemistry.

These processes have been described previously in Section 2.4. The solid wastes generated by these processes fall into three general categories: (1) drummed dry waste, (2) crated dry waste, and (3) drummed liquid waste. The total waste volume generation from the fabrication of fuel pins for FFTF cores 1 and 2 is shown in Table 3-1. This table lists the waste volume generated in each of the categories above by source. The disposition of the waste to scrap recovery, retrievable storage, or shallow land cover also is indicated. The majority of the waste sent to retrievable storage was drummed dry waste. The peak waste volume generated annually was $175.58 \mathrm{~m}^{3}$ in 1975 . 
Pu concentrations in wastes generated by cores 1 and 2 work are given in Table 3-2. This table presents the concentration of Pu by the following categories:

- Drummed dry wastes

- Crated dry wastes

- Drummed liquid wastes.

The greatest concentration of Pu in waste shipped to retrievable storage was found in drummed liquid wastes from the analytical laboratory. Table 3-3 provides a summary of waste shipments to retrievable storage, including the volume of waste in $\mathrm{Kg}$ and the percentage of total Pu loss provided in parentheses for each operating period.

A more detailed description of drummed dry waste, crated dry waste and drummed liquid waste types follows (Bradley and Clark 1978). It is assumed that the fabrication of fuel pins for cores 3 and 4 generated waste types identical to the waste types described below for cores 1 and 2 work.

\subsubsection{Drummed Dry Waste}

3.1.1.1 Line and Laboratory Wastes. Line and laboratory wastes included miscellaneous small items of equipment, electrodes, rubber gloves, plastics, primary filters, etc. Small packages of laboratory wastes, similar to the line wastes, were packaged with line wastes. Other wastes identified from the laboratory operations include the following:

- Leco ${ }^{\circ}$ crucibles, which were used for combustion of mixed-oxide powders

- Discarded glass and metal components

- Pellets in mounts.

Figure 3-1 shows the volumetric distribution of constituents in line generated wastes from cores 1 and 2 work. The Pu distribution among line waste constituents of generated line wastes is shown in Figure 3-2.

3.1.1.2 Non-Line Wastes. Non-line wastes, generally identified as 'non-glovebox waste,' included all materials destined for discard from plant operating and service areas where known or potential radioactive materials contamination existed (e.g., 'controlled zones'). These wastes were commonly

- Packaging materials

- Housekeeping trash

- Cloth and plastic sheet materials

- Used non-radioactive materials containers

- Maintenance scrap

- Decontamination wipes

- Scrap balances.

-Leco is a trademark of Leco Corporation. 
A large fraction of this waste (>75 percent) was 'suspect TRU' waste assayed at nominal zero Pu content.

3.1.1.3 High-Efficiency Particulate Air (HEPA) Filters and Jet Mill Bags. High-efficiency particulate air (HEPA) filters and jet mill bags sent to disposal were specific process items used in all gas handling lines or ducts for particulate removal from gas streams before discharge. A total of 206 drums containing HEPA filters from the production of cores 1 and 2 were shipped to retrievable storage; this included 99 drums at nominal zero Pu assay. Jet mill bags from the fabrication of cores 1 and 2 contributed a minor increment to the waste volume sent to retrievable storage. Essentially the entire volume increment of jet mill bags was sent to offsite scrap recovery at the Hanford Site.

3.1.1.4 Scrap and 'Combined' Wastes. Scrap and 'combined' wastes originated in all controlled zones within the operation facility. Essentially all of this drummed waste was generated during plant maintenance and cleanout operations. Plant maintenance and cleanout operations occurred primarily in calendar year (CY) 1976 in preparation for beginning fuel pin fabrication for FFTF cores 3 and 4 and in CY 1980 through 1983 as Babcock and Wilcox phased out its Plutonium Facility Operations. Scrap items included thie following:

- $\quad$ Spent equipment

- Broken tools

- Furnace brick

- Glovebox windows

- Other items from within the glovebox enclosures too large for paper can containment.

'Combined' wastes included items from more than one originating source. For example a non-line waste increment with added line waste packages became 'combined' waste. (The actual term used by Babcock and Wilcox personnel for this type of waste was 'mixed' waste; however, in this report, the term mixed waste refers to TRU waste that also contains hazardous constituents. To avoid confusion, the Babcock and Wilcox term 'mixed' waste has been replaced with 'combined' waste.) Approximately 42 percent of the volume was assayed at nominal zero Pu. Table 3-4 provides a breakdown of the scrap and combined waste constituents generated during cores 1 and 2 work.

\subsubsection{Crated Dry Waste}

3.1.2.1 Spent HEPA Filters. Spent HEPA filters, other than the primary filters described above in Section 3.1.1, were used in several locations, typically final filter bank installations. The frame dimensions of these filters measures $61 \mathrm{~cm}$ square by $51 \mathrm{~cm}$ long ( $24 \mathrm{in.} \mathrm{square}$ by $20 \mathrm{in}$. long). Over 40 percent of the total crated waste volume from 
cores 1 and 2 work shipped to retrievable storage contained large size HEPA filters. Nearly all of these filters, 95.6 percent of the volume, were assayed at nominal zero $\mathrm{Pu}$ content.

3.1.2.2 Scrap and 'Combined' Wastes. Scrap and 'combined' wastes contained miscellaneous constituents, which were generally identified as 'scrap' or 'general use waste.' Crates were used for packaging these wastes, which included:

- Rejected fuel cladding

- Spent equipment

- Equipment components

- Other parts too large for drum containment.

Over 70 percent of the volume of this shipped waste category was assayed at nominal zero Pu content.

\subsubsection{Drummed Liquid Waste}

3.1.3.1 Scrap recovery liquids. Scrap recovery liquids refer to ion-exchange raffinates. Sludges include insolubles washed from tanks or filtered from process streams and spent resins from ion-exchange columns. Scrap recovery liquids and sludges from cores 1 and 2 work were contained in 299 drums of shipped waste. Sludges, contained in five of the drums, included about $\mathbf{4 5 . 5}$ percent of the total Pu associated with this waste category.

3.1.3.2 Analytical Laboratory Wastes. Analytical laboratory wastes were generated from analyses of solution by procedures required for chemical analysis of selected samples to ensure that fuel product specifications were met. Liquid wastes from the analytical laboratory contain a variety of solutions arising from use of these procedures. The average composition of the laboratory wastes from cores 1 and 2 is given in Table 3-5.

3.1.3.3 Non-Scrap Recovery Liquids. Non-scrap recovery liquids included all other liquids not originating from scrap recovery operations or laboratory analyses. Typical liquids were the following:

$\begin{array}{ll}\text { - } & \text { Sump drainage } \\ \text { - Hydraulic oils } \\ \text { - } \quad \text { Organic solvents } \\ \text { - Subricants } \\ \text { Spent solvents or cleaning solutions. }\end{array}$

Seventy percent of this waste from the fabrication of cores 1 and 2 was classified as 'low specific activity' (LSA) and was acceptable for shallow ground burial disposition at sites other than the Hanford Site. All liquid wastes were immobilized before shipment to the Hanford Site. 


\subsection{TRANSURANIC WASTE "ENERATED DURING DECONTAMINATION AI CLEANOUT}

The TRU waste that was generated during the decontamination and cleanout of the Plutonium Facility came primarily from the repackaging of waste drums and bagging-out of equipment from gloveboxes, cut-up gloveboxes, and other associated equipment. Table 3-6 shows the number of waste containers from the decontamination and decommissioning (D\&D) of the Babcock and Wilcox Plutonium Facility that was shipped to Rockwell Hanford Operations during 1981, 1982, and 1983. The table also provides the grams of Pu and the volume for each container.

\subsection{LOW-SPECIFIC-ACTIVITY WASTE GENERATED AT BABCOCK ANL WILCOX}

In addition to the TRU waste sent to the Hanford Site, LSA waste was sent to the U.S. Ecology Burial Site in Beatty, Nevada (Babcock and Wilcox 1983). From February 980 through November 1982, a total of 291 crates of LSA waste from the D\&D of the babcock and Wilcox Plutonium Facility was buried. 
Figure 3-1. Volumetric Distribution of Constituents in Generated Line Wastes from the Production of Fuel Pins for Cores 1 and 2.

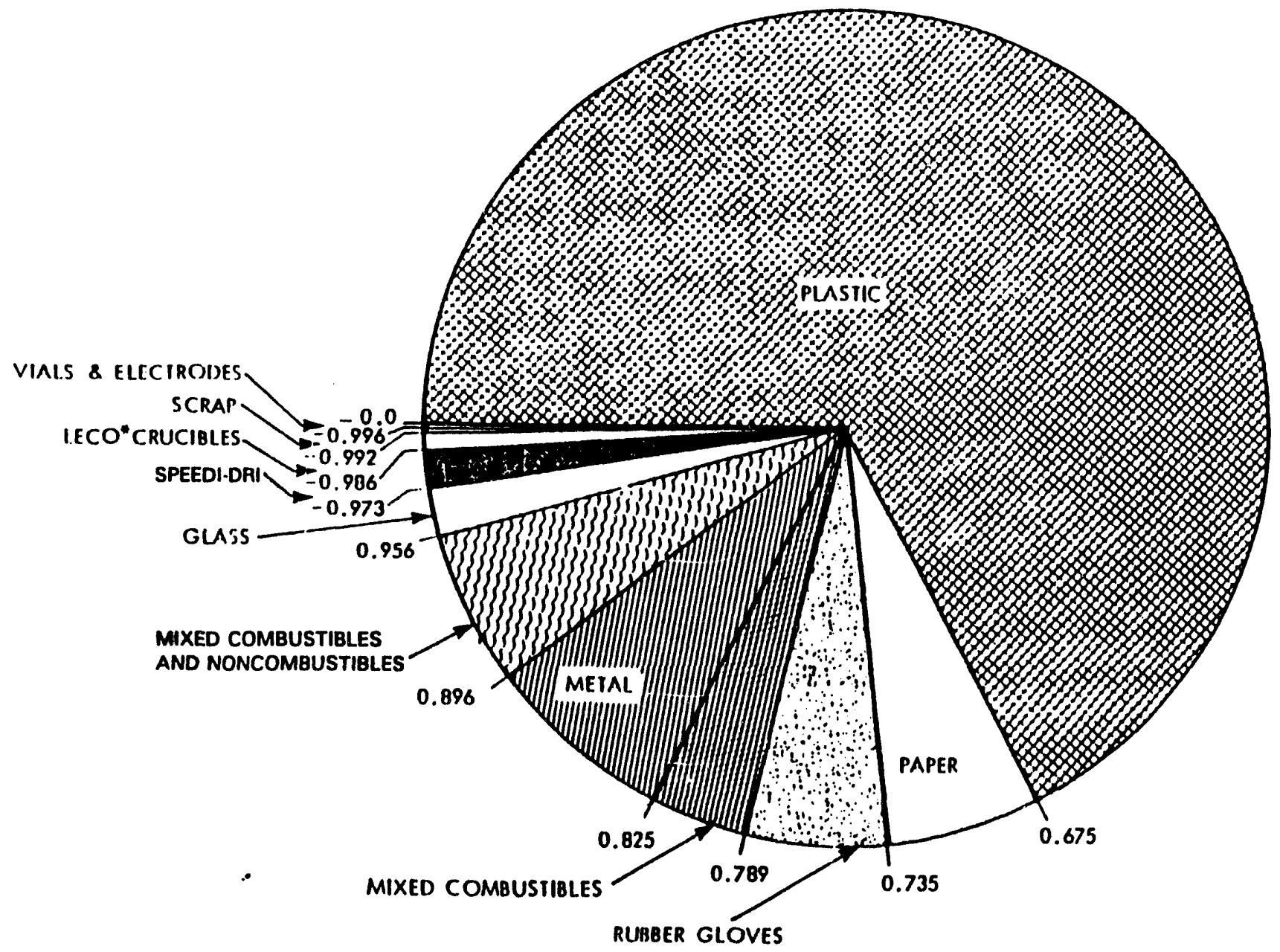

- Leco is a trademark of Leco Corporation 
Figure 3-2. Plutonium Distribution Among Constituents of Lines Wastes Generated.

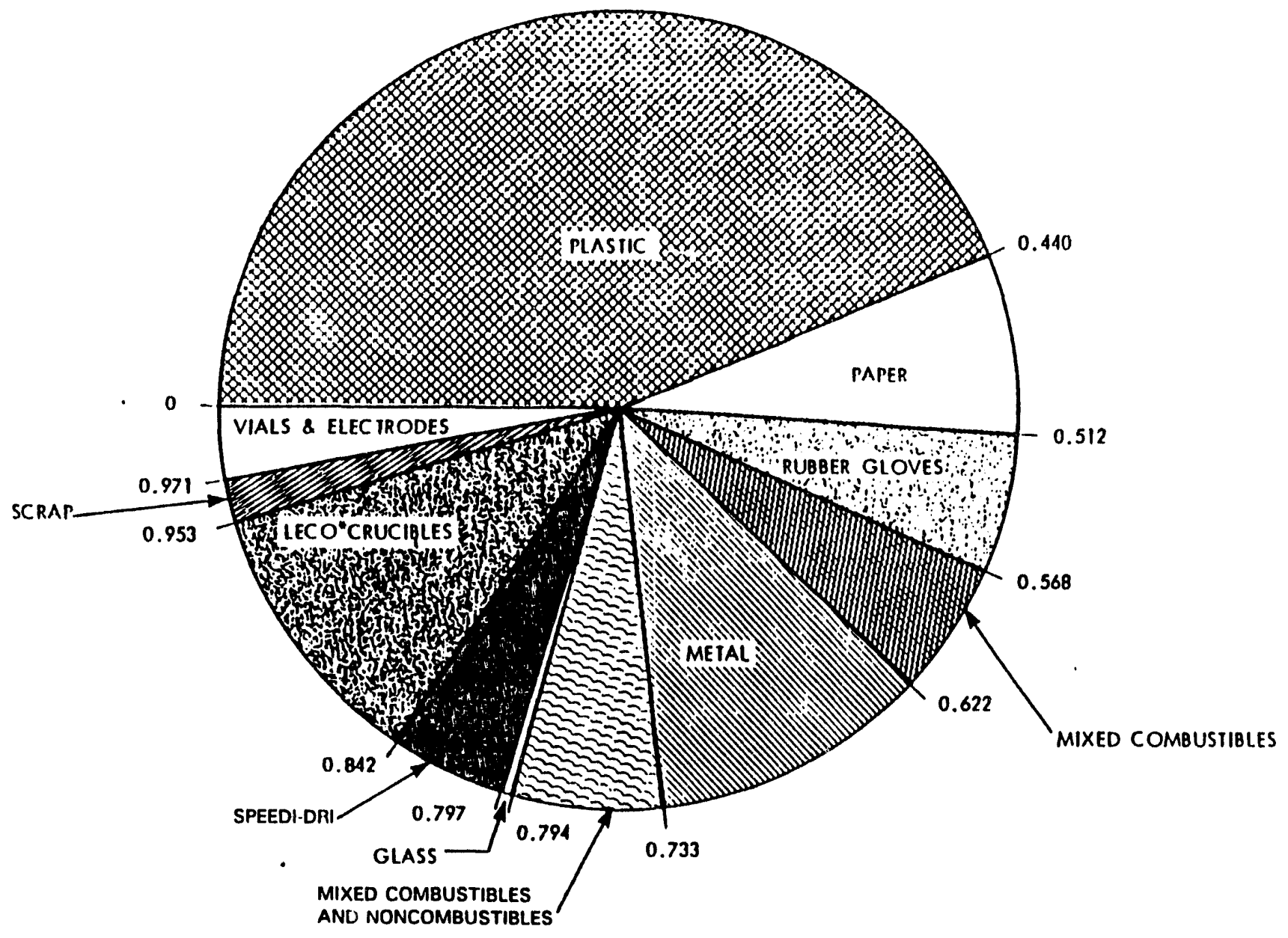

- Leco is a trademark of Leco Corporation 


\begin{tabular}{|c|c|c|c|c|c|c|c|c|c|}
\hline $\begin{array}{l}\text { Origin of waste increment } \\
\text { and type of container }\end{array}$ & \multicolumn{6}{|c|}{ Generated waste volume $\left(\mathrm{m}^{3} / \mathrm{yr}\right)$} & \multicolumn{3}{|c|}{ Disposal to } \\
\hline Line and laboratory & 11.45 & 30.40 & 30.61 & 34.77 & 4.16 & 111.39 & 2.29 & 109.10 & - \\
\hline Non-line & 2.29 & 13.12 & 23.32 & 32.89 & 2.08 & 73.70 & - & 73.70 & - \\
\hline \multicolumn{10}{|c|}{ Crated dry wastes } \\
\hline Spent HEPA filters & - & 1.59 & - & 13.37 & 8.50 & 23.46 & - & 23.46 & - \\
\hline Scrap and mixed & - & - & 13.17 & 5.44 & 15.63 & 34.24 & - & 34.24 & - \\
\hline \multicolumn{10}{|c|}{ Drummed liquid wastes" } \\
\hline Totals & 17.49 & 64.05 & 94.38 & 175.58 & 67.62 & 419.12 & 4.58 & 385.81 & 28.73 \\
\hline
\end{tabular}




\begin{tabular}{|c|c|c|c|c|c|c|c|c|}
\hline \multirow{2}{*}{$\begin{array}{l}\text { Origin of waste increment } \\
\text { and type of container }\end{array}$} & \multicolumn{6}{|c|}{$\begin{array}{l}\text { Year } \\
\left(\mathrm{g} / \mathrm{m}^{3}\right)\end{array}$} & \multicolumn{2}{|c|}{$\begin{array}{l}\text { Plutonium shipped to } \\
\qquad\left(\mathrm{g} / \mathrm{m}^{3}\right)^{\circ}\end{array}$} \\
\hline & 1972 & 1973 & 1974 & 1975 & 1976 & Average & $\begin{array}{l}\text { Scrap } \\
\text { recovery }\end{array}$ & $\begin{array}{c}\text { Retrievable } \\
\text { storage }\end{array}$ \\
\hline \multicolumn{9}{|c|}{ Drummed dry wastes } \\
\hline Line and laboratory & 42.27 & 78.19 & 95.50 & 143.03 & 123.07 & 101.45 & 765.07 & 87.52 \\
\hline Non-line & 0.00 & 2.06 & 7.41 & 24.75 & 2.40 & 13.83 & - & 13.83 \\
\hline HEPA filters and jet mill bags & 30.77 & 74.53 & 97.15 & 62.65 & 2.41 & 72.75 & 862.87 & 41.98 \\
\hline Scrap and mixed & 3.20 & 9.60 & 14.41 & 45.85 & 253.55 & 69.16 & 569.35 & 53.81 \\
\hline \multicolumn{9}{|c|}{ Crated dry wastes } \\
\hline Spent HEPA filters & $\cdot$ & 6.92 & - & 0.52 & 7.65 & 3.54 & - & 3.54 \\
\hline Scrap and mixed & - & - & 0.00 & 0.00 & 10.30 & 4.70 & - & 4.70 \\
\hline \multicolumn{9}{|c|}{ Drummed liquid wastes ${ }^{b}$} \\
\hline SR liquids and sludge & \multicolumn{3}{|c|}{-Non-Operating Period- } & 5.32 & 21.97 & 9.49 & - & 9.49 \\
\hline Analytical Laboratory & 188.09 & 241.18 & 198.08 & 202.40 & 187.10 & 208.05 & - & 208.05 \\
\hline Non-SR liquids & - & 0.00 & 23.47 & 0.00 & 0.00 & 4.29 & - & 14.37 \\
\hline Totals & 36.08 & 56.25 & 55.77 & 44.44 & 34.19 & 46.80 & 774.24 & 41.65 \\
\hline
\end{tabular}

-All immobilized liquid waste shipped to shallow land cover assayed as $0 \mathrm{~g} / \mathrm{m}^{3}$.

'Liquid wastes are immobilized before shipment.

$S R=$ scrap recovery. 


\begin{tabular}{|c|c|c|c|c|c|c|}
\hline \multirow{2}{*}{ Origin of waste increment } & & \multirow{2}{*}{$\frac{\text { Process tests }}{1972-1973}$} & \multicolumn{3}{|c|}{ Production operations } & \multirow{2}{*}{$\begin{array}{c}\text { Total to } \\
\text { retrievable } \\
\text { storage }\end{array}$} \\
\hline & & & 1973 & 1974 & 1975 & \\
\hline \multirow[t]{2}{*}{ Line and laboratory } & $m^{3}$ & 14.91 & 27.66 & 31.14 & 35.39 & 109.10 \\
\hline & $\%$ & $(4.71)$ & $(13.70)$ & $(14.41)$ & (26.61) & (59.43) \\
\hline \multirow[t]{2}{*}{ Non-line } & $m^{3}$ & 2.98 & 12.78 & 24.12 & 33.82 & 73.70 \\
\hline & $\%$ & $(0.01)$ & $(0.16)$ & $(1.09)$ & (5.08) & $(6.34)$ \\
\hline \multirow[t]{2}{*}{ HEPA filters and jet mill bags } & $m^{3}$ & 2.70 & 8.47 & 12.87 & 18.84 & 42.88 \\
\hline & $\overline{\%}$ & (0.69) & (3.86) & $(3.90)$ & $(2.75)$ & $(11.20)$ \\
\hline \multirow[t]{2}{*}{ Scrap and mixed } & $m^{3}$ & 1.63 & 6.91 & 5.36 & 6.30 & 20.20 \\
\hline & $\%$ & $(0.05)$ & $(0.40)$ & (3.44) & $(2.86)$ & $(6.76)$ \\
\hline \multirow[t]{2}{*}{ Spent HEPA filters } & $\mathrm{m}^{3}$ & - & 4.02 & 9.02 & 10.42 & 23.46 \\
\hline & $\%$ & - & $(0.09)$ & $(0.20)$ & $(0.23)$ & $(0.52)$ \\
\hline \multirow[t]{2}{*}{ Scrap and mixed } & $\overline{m^{3}}$ & - & - & 15.89 & 18.35 & 34.24 \\
\hline & $\%$ & - & - & $(0.47)$ & (0.53) & $(1.00)$ \\
\hline \multirow[t]{2}{*}{ SR liquids and sludge } & $m^{3}$ & - & 10.67 & 23.94 & 27.64 & 62.25 \\
\hline & $\%$ & - & (0.63) & $(1.42)$ & $(1.63)$ & (3.68) \\
\hline \multirow[t]{2}{*}{ Analytical Laboratory } & $m^{3}$ & 0.54 & 1.23 & 2.75 & 3.18 & 7.70 \\
\hline & $\%$ & (0.68) & $(1.60)$ & (3.57) & (4.12) & $(9.97)$ \\
\hline \multirow[t]{2}{*}{ Non-SR liquids } & $m^{3}$ & - & 3.54 & 13.58 & 23.89 & 41.01 \\
\hline & $\%$ & - & $(0.00)$ & $(1.10)$ & $(0.00)$ & $(1.10)$ \\
\hline \multicolumn{2}{|l|}{ Volume shipped $\left(\mathrm{m}^{3}\right)$} & 22.75 & 75.28 & 138.67 & 177.83 & 414.54 \\
\hline \multicolumn{2}{|l|}{ Pu in period, \% of total loss } & (6.13) & $(20.42)$ & $(29.64)$ & $(43.81)$ & $(100.00)$ \\
\hline
\end{tabular}


Table 3-4. Scrap and Combined Waste Constituents for Drummed Dry Waste Generated During Cores 1 and 2 Work.

\begin{tabular}{|c|c|c|c|c|}
\hline \multicolumn{2}{|c|}{ Number of drums } & \multicolumn{1}{|c|}{ Description of drum contents } & \multicolumn{2}{c|}{ Percent of category } \\
\cline { 1 - 5 } Total & $\begin{array}{c}\text { Nominal } \\
\text { O.0g Pu }\end{array}$ & \multicolumn{1}{|c|}{$\begin{array}{c}\text { Pu } \\
\text { content }\end{array}$} \\
\hline $14^{\circ}$ & 0 & $\begin{array}{l}\text { Non-line wastes with selected Pu-bearing } \\
\text { waste packages transferred from 31 other } \\
\text { drums }\end{array}$ & 14.43 & 74.23 \\
\hline $25^{b}$ & 10 & $\begin{array}{l}\text { Scrap equipment, vault parts, mixed large } \\
\text { glovebox scrap, and equipment parts }\end{array}$ & 25.78 & 10.45 \\
\hline 10 & 0 & $\begin{array}{l}\text { Miscellaneous waste not specifically } \\
\text { named }\end{array}$ & 10.31 & 6.58 \\
\hline 2 & 0 & Empty metal and plastic containers & 2.06 & 4.94 \\
\hline 10 & 2 & Scrap balances & 10.31 & 2.76 \\
\hline 3 & 0 & Laboratory scrap and insulator pellets & 3.09 & 0.49 \\
\hline 21 & 19 & Furnace brick and parts & 21.65 & 0.31 \\
\hline 1 & 0 & Decontamination and cleanup wastes & 1.03 & 0.21 \\
\hline 8 & 7 & $\begin{array}{l}\text { Glovebox windows and parts and } \\
\text { greenhouse remnants }\end{array}$ & 8.25 & 0.03 \\
\hline 3 & 3 & Apollo (U only) and utility room filters & 3.09 & 0.0 \\
\hline 97 & 41 & Totals & 100.00 & 100.00 \\
\hline
\end{tabular}

-All of these drums contain added waste packages.

'Seven of these drums contained large size glovebox waste packages.

Typical equipment and parts included the following: scrap batteries; jet mill parts; vault doors and parts; pressure cooker; V-blender; ball mill parts; Syntron " glassware; glovebox floor parts; and scrap balances.

$\mathrm{Pu}=$ plutonium.

\footnotetext{
Apollo is a trademark of International Water Technologies.

•-Syntron is a trademark of FMC Corporation.
} 
Table 3-5. Average Composition of Analytical Laboratory Liquid Wastes from Cores 1 and 2.

\begin{tabular}{|c|c|c|}
\hline Analysis producing the waste & $\begin{array}{l}\text { Plutonium } \\
\text { concentration } \\
\text { (ppm) }\end{array}$ & $\begin{array}{l}\text { Percentage of } \\
\text { total waste } \\
\text { volume }\end{array}$ \\
\hline Chloride plus fluoride & $<100$ & 22.9 \\
\hline $\begin{array}{l}\text { Phosphorus } \\
\text { Contains butanol with methanol, acetone }\end{array}$ & $\begin{array}{r}150 \\
<100\end{array}$ & $\begin{array}{r}11.4 \\
2.4\end{array}$ \\
\hline $\begin{array}{l}\text { Tungsten } \\
\text { Contains titanium, chloride, sulfate }\end{array}$ & 400 & 8.4 \\
\hline Contains pentylacetate methanol, acetone & $<100$ & 3.1 \\
\hline $\begin{array}{l}\text { Rare earths } \\
\text { Contains tri-N-octylamine-xylene mixture, } \\
\text { acetone and methanol }\end{array}$ & $\begin{array}{r}<100 \\
400\end{array}$ & $\begin{array}{l}6.3 \\
3.6\end{array}$ \\
\hline $\begin{array}{l}\text { Nitrogen } \\
\text { Contains } \mathrm{Cl}, \mathrm{F} \text {, and excess of } \mathrm{NaOH}\end{array}$ & $\begin{array}{r}<100 \\
400\end{array}$ & $\begin{array}{l}9.7 \\
8.2\end{array}$ \\
\hline Isotopic analysis & $<100$ & 4.8 \\
\hline $\begin{array}{l}\text { Plutonium } \\
\text { Cleaning liquid } \mathrm{H}_{2} \mathrm{SO}_{4}, \mathrm{Ag}_{2} \mathrm{SO}_{4}, \mathrm{Fe} \text { (III) } \\
2 \mathrm{M} \mathrm{H}_{2} \mathrm{SO}_{4}, 10 \% \mathrm{NaHSO}_{4}+\text { trace of } \mathrm{HNO}_{3}\end{array}$ & $\begin{array}{r}<100 \\
400 \\
1000\end{array}$ & $\begin{array}{l}\mathbf{5 . 0} \\
\mathbf{5 . 0} \\
\mathbf{5 . 2}\end{array}$ \\
\hline Uranium--Titrimetric & $<100$ & 3.6 \\
\hline $\begin{array}{l}\text { Uranium--Photometric } \\
\text { Contains tin, chloride, hydroxylamine }\end{array}$ & $\begin{array}{l}100 \\
800\end{array}$ & $\begin{array}{l}0.2 \\
0.2\end{array}$ \\
\hline
\end{tabular}


WHC-EP-0719

Table 3-6. Transuranic Waste Shipments to Richland, Washington. (2 sheets)

\begin{tabular}{|c|c|c|c|c|c|}
\hline \multirow{2}{*}{$\begin{array}{l}\text { Shipment } \\
\text { number }\end{array}$} & \multirow{2}{*}{ Date } & \multirow{2}{*}{$\begin{array}{c}\text { Plutonium } \\
\text { (D) }\end{array}$} & \multicolumn{2}{|c|}{ Volume } & \multirow{2}{*}{ Description } \\
\hline & & & $m^{3}$ & $\mathrm{ft}^{3}$ & \\
\hline $3536-1$ & $06 / 19 / 81$ & 982 & 14.0 & 495 & 66 drums \\
\hline-2 & $07 / 10 / 81$ & 1,135 & 16.1 & 570 & 76 drums \\
\hline-3 & $07 / 24 / 81$ & 1,136 & 16.1 & 570 & 76 drums \\
\hline-4 & $08 / 07 / 81$ & 1,122 & 16.1 & 570 & 76 drums \\
\hline-5 & $08 / 21 / 81$ & 1,019 & 16.1 & 570 & 76 drums \\
\hline .6 & $09 / 08 / 81$ & 1,019 & 16.1 & 570 & 76 drums \\
\hline-7 & $09 / 18 / 81$ & 943 & 15.9 & 563 & 75 drums \\
\hline-8 & $10 / 02 / 81$ & 1,060 & 16.1 & 570 & 76 drums \\
\hline-9 & $10 / 21 / 81$ & 1,140 & 16.1 & 570 & 76 drums \\
\hline-10 & $11 / 06 / 81$ & 1,115 & 16.1 & 570 & 76 drums \\
\hline-11 & $12 / 29 / 81$ & 1,079 & 16.1 & 570 & 76 drums \\
\hline \multicolumn{2}{|c|}{1981 total } & 11,750 & 175.2 & 6,188 & 825 drums \\
\hline $3536-12$ & $03 / 12 / 82$ & 164 & 12.9 & 455 & Crates MK-1-1 and 1-7, 6 drums \\
\hline-13 & $04 / 15 / 82$ & 364 & 14.1 & 500 & Crates MK-1-9 and 1-5, 12 drums \\
\hline-14 & $05 / 14 / 82$ & 275 & 11.6 & 410 & Crates MK-1-6 and 1-8 \\
\hline-15 & $06 / 04 / 82$ & 20 & 11.6 & 410 & Crates MK-1-4 and 1-10 \\
\hline-16 & $06 / 18 / 82$ & 80 & 7.9 & 279 & $\begin{array}{c}1 \text { Crate MK-1-2 and } 1 \text { stainless } \\
\text { steel tank }\end{array}$ \\
\hline-17 & $07 / 16 / 82$ & 209 & 10.7 & 378 & Crates MK-1-3 and 1-70 \\
\hline-18 & $08 / 23 / 82$ & 333 & 9.8 & 346 & Crates MK-1-66 and 1-67 \\
\hline-19 & $10 / 18 / 82$ & 279 & 9.8 & 346 & Crates MK-1-68 and 1-57 \\
\hline
\end{tabular}


Table 3-6. Transuranic Waste Shipments to Richland, Washington. (2 sheets)

\begin{tabular}{|c|c|c|c|c|c|}
\hline \multirow{2}{*}{$\begin{array}{l}\text { Shipment } \\
\text { number }\end{array}$} & \multirow{2}{*}{ Date } & \multirow{2}{*}{$\begin{array}{c}\text { Plutonium } \\
(\mathrm{g})\end{array}$} & \multicolumn{2}{|c|}{ Volume } & \multirow{2}{*}{ Description } \\
\hline & & & $m^{3}$ & $\mathrm{tt}^{3}$ & \\
\hline $4242-1$ & $11 / 05 / 82$ & 117 & 9.8 & 346 & Crates MK-55 and MK-56 \\
\hline-2 & $11 / 12 / 82$ & 668 & 16.2 & 571 & 76 drums \\
\hline-3 & $11 / 19 / 82$ & 10 & 6.1 & 216 & 2 stainless steel tanks \\
\hline-4 & $12 / 03 / 82$ & 15 & 3.6 & 127 & 2 stainless steel tanks \\
\hline-5 & $12 / 17 / 82$ & 59 & 7.96 & 281 & $\begin{array}{c}\text { Crate MK-64 and } 1 \text { stainless steel } \\
\text { tank }\end{array}$ \\
\hline-6 & $12 / 17 / 82$ & 72 & 16.1 & 570 & 76 drums \\
\hline \multicolumn{2}{|c|}{1982 total } & 2,665 & 148.2 & 5.235 & \\
\hline $4242 \cdot 7$ & $01 / 12 / 83$ & 0 & 16.1 & 570 & 76 drums \\
\hline-8 & $03 / 04 / 83$ & 47 & 16.1 & 570 & 76 drums \\
\hline-9 & $03 / 04 / 83$ & 31 & 11.8 & 416 & Crates MK-65 and MK-69 \\
\hline \multicolumn{2}{|c|}{1983 total } & 78 & 44.1 & 1,556 & \\
\hline \multicolumn{2}{|c|}{ Grand total } & 14,493 & 367.53 & 12,979 & $\begin{array}{l}147 \text { drums } \\
20 \text { crates } \\
6 \text { tanks }\end{array}$ \\
\hline
\end{tabular}




\subsection{SOLID WASTE HANDLING PRACTICES AND PROCEDURES}

This section describes the handling and packaging procedures for Babcock and Wilcox waste from the fabrication of cores 1 and 2 and the D\&D of the facility. No information that describes the packaging and handling of waste produced during the period of cores 3 and 4 fabrication is available. It is assumed that the practices and procedures used by Babcock and Wilcox to handle wastes from cores 1 and 2 fuel pin fabrication is similar to that used for cores 3 and 4. Included at the end of this section are examples of the shipping and accountability checklists used by Babcock and Wilcox personnel. These checklists may provide additional handling and packaging information. Figure 4-1 is the Materials Control and Accountability Burial Shipment Checklist. Figure 4-2 is the Materials Control Box or Drum Checklist; a Burial Shipment Checklist is shown in Figure 4-3. In addition to describing waste packaging and handling at Babcock and Wilcox, Section 4.3 describes the solid waste acceptance criteria at the Hanford Site during the time period during which the waste was sent.

\subsection{HANDLING AND PACKAGING OF FUEL PIN FABRICATIUN WALIE}

\subsubsection{Handling and Packaging of Drummed Dry Waste}

4.1.1.1 Line and Laboratory Wastes. Line and laboratory wastes were bagged out of production line glovebox containment into about 6-L (nominal 1 1/2-gal) paper cans. After assay, these cans were loaded into 17C 55-gal steel drums before disposal. Small packages of laboratory wastes that were similar to the line wastes were included with line wastes.

The common practice was to sweep all powder from glovebox waste (i.e., gloves, plastic, glass, paper, etc.) before packaging. The fingers were cut off the gloves to eliminate air pockets during compaction. Glassware was placed in metal containers, crushed, and double-bagged. Metal cans were cleaned with a wire brush, the interior and exterior were painted with a latex paint, allowed to dry, and then compacted.

Glovebox/hood equipment had all sharp edges removed with a file. If unable to be filed, the edges were covered with tape. The entire piece of equipment was painted, allowed to dry, and double-bagged.

4.1.1.2 Non-Line Waste. Non-line waste was generally identified as 'non-glovebox' waste. Some of the non-line waste drum contents were compscted to approximately half of their initial bulk volume.

4.1.1.3 Primary HEPA Filters. Primary HEPA filters were packaged one per 17C 55-gal drum. They were of $30-\mathrm{cm}$-square by $45-\mathrm{cm}$-long $(12$-in.-square by 18 -in.-long) frame configuration with end piping adaptors for inline installation.

4.1.1.4 Jet Mill Bags. Jet mill bags were contained in 6-L (1 1/2-gal) paper cans. 
4.1.1.5 Scrap and 'Combined' Drummed Waste. Scrap and 'combined' drummed waste, transferred to scrap recovery, were identified as 'dry bagged waste' rather than by particular materials or named items in contained packages (Bradley and Clark 1978).

\subsubsection{Crated Dry Waste}

4.1.2.1 Spent HEPA Filters. Spent HEPA filters, other than the primary filters described above, of $60-\mathrm{cm}$-square by 50.8 -cm-long (24-in.-square by 20 -in.-long) frame dimensions were used in several locations, typically final filter bank installations. Spent HEPA filters too large for 55-gal drum containment were enclosed within rectangular boxes. In most cases single filters were contained in $.31 \mathrm{~m}^{3}\left(11 \mathrm{ft}^{3}\right)$ boxes. Up to four filters were packaged in some of the larger boxes.

4.1.2.2 Scrap and 'Combined' Wastes. Scrap and 'combined' wastes (reject fuel cladding, general use waste, and equipment components) were packaged in crates ranging in size from $0.25 \mathrm{~m}^{3}$ to $3.4 \mathrm{~m}^{3}$. Spent equipment and parts too large for drum containment were contained in other crates (Bradley and Clark 1978).

\subsubsection{Drummed Llquid Wastes}

4.1.3.1 Liquid Wastes. Liquid wastes from the fabrication of cores 1 and 2 were immobilized within 17-C ste日l drum containment by absorption on Speedi-Dri (vermiculite), before shipment offsite. Drums were not provided with vent clips; however, they were outgassed before being sealed. After about 1980, no liquid waste in Floor-Dry was permitted to be sent to burial. All liquid waste had to be solidified in cement.

4.1.3.2 Hot Cell Liquid Wastes. Hot cell liquid wastes were solidified in concrete mix or Portland cement (Babcock and Wilcox 1983).

4.1.3.3 Contaminated Hydraulic and Vacuun Pump Oll. Contaminated hydraulic and vacuum pump oil was mixed with sand and Portland cement. Water was added to the mixture to produce a slurry. The oil did not separate after addition of the water or after solidification (Babcock and Wilcox 1983).

\subsection{HANDLING AND PACKAGING OF TRANSURANIC DECONTAMINATION AND DECOMMISSIONING WASTE}

\subsubsection{Repackaging of Waste}

At the completion of FFTF contract manufacturing, a 300-drum inventory of waste ranging from 10 to $100 \mathrm{~g}$ of Pu per drum and 58 primary and secondary filters each containing 1 to $30 \mathrm{~g}$ of Pu resulted in a waste inventory with a total of $8.8 \mathrm{~kg}(19.4 \mathrm{lb})$ of Pu. This waste could not be shipped as packaged in the Super Tiger since only a nondispersable form of Pu could be shipped in that container. Because of these shipping restrictions, an N-55 shipping container, which allowed transportation of 76 55-gal drums 
per trailer, was select $\mathrm{J}$. However, the $\mathrm{N}-55$ overpack container was limited to $15 \mathrm{~g} \mathrm{of} \mathrm{Pu}$ per drum. The previously packaged inventory of waste did not meet this limit and had to be repackaged and recounted so that the total quantity of Pu per drum was equal to or less than $15 \mathrm{~g}$.

Repackaging resulted in the generation of additional waste because the previously packaged waste had to be bagged into the glovebox system and work within the glovebox generated more waste, chiefly plastic and gloves. Additionally, a single 15-g waste carton package (15-cm diameter by $30 \mathrm{~cm}$ long [6-in. diameter by $12 \mathrm{in.} \mathrm{long])} \mathrm{would} \mathrm{not}$ effectively use the available volume in a 55-gal drum. In some cases, the remaining volume was filled with zero value waste or LSA waste. Also, since $60-\mathrm{cm}$ by $60-\mathrm{cm}$ by 50-cm (24-in. by 24-in. by 20-in.) filters would not fit inside a 55-gal drum, these filters and $30-\mathrm{cm}$ by $30-\mathrm{cm}$ by $60-\mathrm{cm}(12-\mathrm{in}$. by $12-\mathrm{in}$. by $24-\mathrm{in}$.) filters were cut up and repackaged.

Repackaging of the 349 drums of waste remaining after completion of FFTF contract manufacturing resulted in 744 drums of waste for burial (Babcock and Wilcox 1983).

\subsubsection{Gloveboxes and Special Equipment}

The regulations and restrictions relative to transporting TRU waste to Rockwell Hanford required that gloveboxes and equipment be decontaminated to a specific level of removable contamination and a polyvinyl alcohol fixative applied. During the D\&D of the Babcock and Wilcox Plutonium Facility, 56 gloveboxes were decontaminated, disassembled, cut into pieces, placed in plastic polyvinyl chloride (PVC) bags, and smeared before packaging in steel burial crates. The edge of each package was wrapped with foam to prevent the cut surfaces and sharp corners from puncturing the PVC bags. The foam was taped in place with duct tape and then a plastic PVC sheet was unrolled and taped in place under the glovebox floor. A five-sided PVC envelope was then placed over the package and taped in place.

The jet mill, hydraulic press, and slug press were decontaminated, disassembled, and packaged with techniques similar to those previously described for gloveboxes and equipment. The Fab 1 and Fab 3 sintering furnaces were disassembled by removing all of the brickwork and double-bagging the brick for storage as TRU waste (Babcock and Wilcox 1983).

\subsection{WASTE PACKAGING AND HANDLING REQUIREMENTS AT THE HANFORD SITE}

Eleven historical waste packaging manuals were reviewed for information regarding packaging and labeling requirements for TRU waste in retrievable storage at the Hanford Site. These manuals covered requirements from 1974 through 1988 . Babcock and Wilcox shipped waste to the Hanford Site beginning in the mid-1970's and ending in 1983. 
Packaging requirements have changed over time and have become more stringent. Table 4-1 summarizes TRU storage requirements for the Hanford Site from 1974 through 1988. The columns in Table 4-1 are not symmetrical; when a definition or requirement is consistent between manuals, text is shared under several document number columns. A blank spot indicates that no requirements or definitions are found in that manual. Definitions (i.e., hazardous and toxic materials, etc.) change from manual to manual and so require reference to each particular manual.

Some of the more significant changes that have occurred in the past 20 years with regard to the packaging, handling, and record keeping for radioactive wastes that were sent from Babcock and Wilcox for retrievable storage at the Hanford Site are as follow:

- The definition of TRU waste has changed since 1970, and the designation of waste packages as TRU also has changed. During the period from 1970 to 1973, TRU segregation was based on generator practice. From 1974 until 1982, TRU waste was segregated if the concentration of TRU was greater than $10 \mathrm{nCi} / \mathrm{g}$. In 1982, the current $100 \mathrm{nCi} / \mathrm{g}$ definition for TRU waste was implemented by the DOE.

- Because of the varied contents of the waste containers, chemical reactions can occur. Gases may accumulate, including hydrogen that can contribute to fire and/or explosion. Since 1982, waste materials that generate $\mathrm{H}_{2}, \mathrm{O}_{2}$, or $\mathrm{NO}_{x}$ are prohibited unless drums have been permanently fitted with vent clips to allow continual release of gases or include catalyst packs to recombine any hydrogen that may be produced.

- Criticality specifications limited the amount of TRU to less than $250 \mathrm{~g}$ per 55-gal drum from 1975 to 1978 and to $200 \mathrm{~g}$ per drum after that time. Before 1975 the criticality limit on drums and cartons was $400 \mathrm{~g}$.

- Individual container weights were not required before 1977; however, estimated weights for pre-1977 containers were added to the records in the R-SWIMS database during the data reentry program in the mid-1980's. Standard weights were given for each container type. All 55-gal drums, for example, were given a value of $68 \mathrm{~kg}(150 \mathrm{lb})$.

- Originally, waste burial records for TRU were not done for individual containers, but for entire shipments. In 1982, TRU burial and storage records began to be based on an individual container basis. Tho entry of unique data for each waste container into the R-SWIMS database was not fully impleinented until 1984. During the R-SWIMS reentry program, historical TRU records were converted to an individual basis so that today there is one SWITS record for each TRU container stored at the Hanford Site.

The conversion from group data to individual container data required some assumptions about the containers in the group to be made. Chief among these assumptions was that an even distribution of radiological and hazardous constituents existed among the members of the group. 
LLW records are still kept for multiple containers rather than for individual containers.

- Information on the hazardous constituents of waste containers was not required before 1986. During the R-SWIMS reentry program any available information from the SWBRs was added. However, this information is limited.

- Physical descriptions of the waste contents were not required on the SWBR before 1978. SWITS records for waste buried before 1978 list the contents as 'miscellaneous' in most cases. In more recent years, the physical contents description has become more detailed. Many of the records now include the weight and volume percentages of a given component in the waste container.

- Between 1972 and 1978, combustible and noncombustible waste components were segregated. Although the SWITS database did not retain a data field for this information, it was added to the physical contents description field.

- The most common TRU waste container used at the Hanford Site is the 55-gal steel drum. U. S. Department of Transportation (DOT) 17C or $17 \mathrm{H}$ drums with minimum wall thicknesses of $.135 \mathrm{~cm}(.053 \mathrm{in}$.$) and$ $.109 \mathrm{~cm}$ (.043 in.), respectively, were both used. Before 1982, most of the drums were painted, so there is approximately .005 in. of paint on both the exterior and interior of the drums. In 1982, galvanized drums replaced the painted drums. Recycled 55-gal drums also were permitted for the storage of TRU waste from 1973 to 1978. 


\section{PLUTONIUM FACILITY}

MATERIALS CONTROL \& ACCOUNTABILITY BURIAL SHIPMENT CHECK LIST

CONOITION

1. Boxes or drums have beer approved by quality Assurance

2. Each itea has been visually inspected and determined to be free of liquid

3. Accountability values for each 1 tem(s) does not exceed the range of the NOA Standard

4. The Pu value does not exceed 15 gms Pu per drum. Isotopic values have been assigned via traceability to the contract.

5. Burial dru lids have been fastened down with a closure ring and bolt. Burial boxes were foamed and nalled according to approved Procedures.

6. Appropriate tamper indicating devices have been applied to each box or drum.

7. Approved TWX received from HEDL or Rockwell with appropriate shipnent numbers. Approved TWX recelved from NECO for LSA Waste.

8. Appl icable Internal drum or box number, Customer Shipment Number, gross weight and Mon-Combust Ible(if eppl icable) printed on the boxes or drums.

9. Boxes or Orums measured for $\mathrm{Ft}^{3}$ determination

10. Approprlate B8W Data Sheets, Shipper's Check List and Customer Data Ferms cumpleted.

11. Hea ith \& Safety has smeared the shipment no more than (24) hours prfor to the shipment.

12. Copies of all Internal and Customer Data Sheets have been forwarded to the Accountability Representative.

13. NRC/DOE-741 prepared, signed and forwarded to the appropriate Plutonium Fecflity personnel.

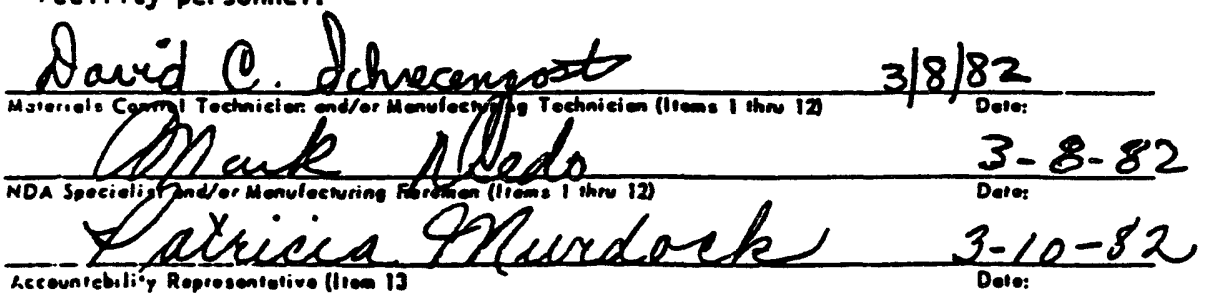

REQUIREAENT

10 CFR $71.51(A)$

10 CFR 71.51 (A)

Plutonium Decomissioning FNMCP

Rockwell Conditions and

Site Criteri

10 CFR 70.58(e)

Internal Requirements/

NECO and/or Rockwell Conditions

and site Criteria

10 CFR $70.51(e)(i)(i)$

Internal Requirement and

10 CFR 70.51(e)(1)(i)

Contractual Provisions or NECO and/or Rockwell site Criteria

10 CFR 79.51(e)(1)(i) and (1)(iv)

NECN and/or Rockwell site Criteria

MECO and/or Rockwell Site Criteria

Internal Requirements and

10 CFR 70.51(e)(1)(iv)

Health \& Safety Manual and

Site Criteria

10 CFR 70.54

10 CFR 70.54

TECHNICIAN

YES NO N/A

$\frac{1}{L}-$

$L--$

-

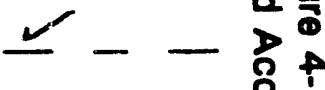

$\checkmark$ 으.

- -

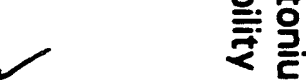

- - -

$\angle--$ 흐

$L--$ 을

-

$\angle-$

shipment Numbor: $R B M-3536-12$

NRr,JDOE TAI No: HAX-VRA \#12 


\section{PLUTONIUM FACILITY}

MATERIALS CONTROL - BOX OR ORUM CHECK LIST

\section{COMOITIOH}

1. The box or Orum has been approved by Quallty Assurance

2. Assigned Interial and Customer Box. Orum, and Shipment Mumber

3. The items placed in the box or drum have been visuelly inspected and determined to be free of liquid

4. Accoutstability values for each 1 tera(s) does not exceed the range of "2A Standerds

5. Huslear Safaty Sheet (If applicable) has been completed and agrees with the stretc Card.

6. The Pu Value does not exceed 15 cans Pu per drum. Isotopic values have been assigned via traceability to the contract.

7. The burial drum lids have been fastened down with a closure ring and belt. and the approprlate tamper indleating device. has been applied to each drum.

8. The burial box IId has been caulked prior to nalling the box closed, and the approprlate tamper indieating device has been applfed to the and the approprlate

49 CFR 173.392

Box ar anuh no. $\beta-335$

\section{TECHIiICIAN}

REQUIREMENT

10 CFR 7.51 (A)

10 CFR $71.51(\mathrm{~A})$

$$
\begin{aligned}
& k=ニ \\
& \underline{K}=- \\
& k-- \\
& --K \\
& k-- \\
& --K \\
& k--
\end{aligned}
$$

Pluton
FNMCP

Internal Requirements
10 CFR $70.51(E)(1)(11)$

Rockwell Condittons and

S1 te Criteria

10 CFR 70.58(E)

10 CFR $70.51(e)(1)(1)$.

NECO and/or Rockrrell
Conditions and Site Criterle

10 CFR 70.51 (e)(1)(1)
Conditions and Site Criterts

NECO and/or Rockwe $\{f$

Conditions and Site Criteria

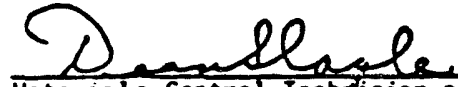

Haterials Control Techrician and/or Manufacturing Techntcian

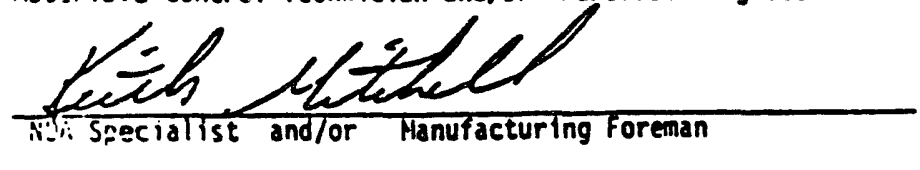


Figure 4-3. Burial Shipment Checklist.

312.7028

Rev. $4: 2 / 81$

SHIPMENT TO: Rect weel Har Fond, Richlad, wA.

DATE: (3- $2 \cdot 82$

PACKING SLIP NO : 22198

TRUCK/TRAILER: $84056-1$ TRUCK/TRAILER SHEARED BEFORE LOADING:

\begin{tabular}{|c|c|}
\hline & CONDITION \\
\hline 1. & $\begin{array}{l}\text { BOXES } \\
\text { A. Melal Banded } \\
\text { B. Stenciled Radioactive - LSA } \\
\text { C. Gross Weight Al flixed }\end{array}$ \\
\hline 2. & $\begin{array}{l}\text { DRUMS } \\
\text { A. Stenciled Radioactive - LSA } \\
\text { B. Gross Weight Altixed } \\
\text { C. Palletized (il over } 600 \text { lbs.) }\end{array}$ \\
\hline
\end{tabular}

3. LOAD

A. Properly braced and chained

B. Drums on front of trailer (If mixed drum/box shipment)

C. Box clearance in van acceptable

D. Tarped or in van trailer

E. Placarded

49.CFR.173.392(c) 8

49.CFR.172.310 (a)

CNSI Site Criteria 2.1.1

CNSI Sile Criteria 2.1.3.C 49.CFR.173.392(c) B 49.CFR.172.310 (2)

4. SHIPPING PAPERS

A. Shipper's checklist

B. Packing slip

C. Bill of Lafing

49.CFR.172.204

D. Certiticale of Compliance "Radiation Monitoring Report"

E. CNSI-201 (4/80) Burial Form

F. Radioactive Waste Shipment \& Disposal Form - NECO

G. Exclusive Use Instruetions for Driver

H. Certification of Understanding Beally, NV. (NECO) - License 113-11-0043-02

1. State Compliance Certification, Beatty, NV, (NECO)

3. Material Acknowledgment Receipt Card

N Nae VeciEiseTn

49.CFR.173.392(c) 6

CNSI Sile Criteria 2.1.4

$A$ and $B$

CNSI Site Criteria 2.1.3

$A$ and $B$

49.CFR.173.392(c) 7

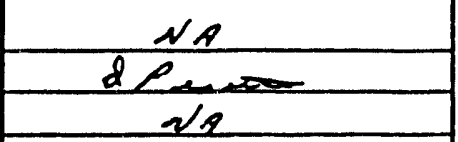

CNSI Site Criteria 9.0

49.CFR.173.392 (c) 9

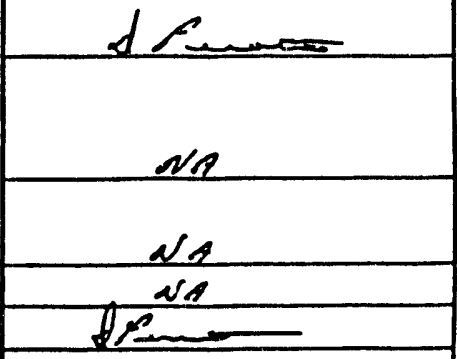

Executi ve Order Dated 7/24/79

Approval of Shipment Sibervisor, Transportation 


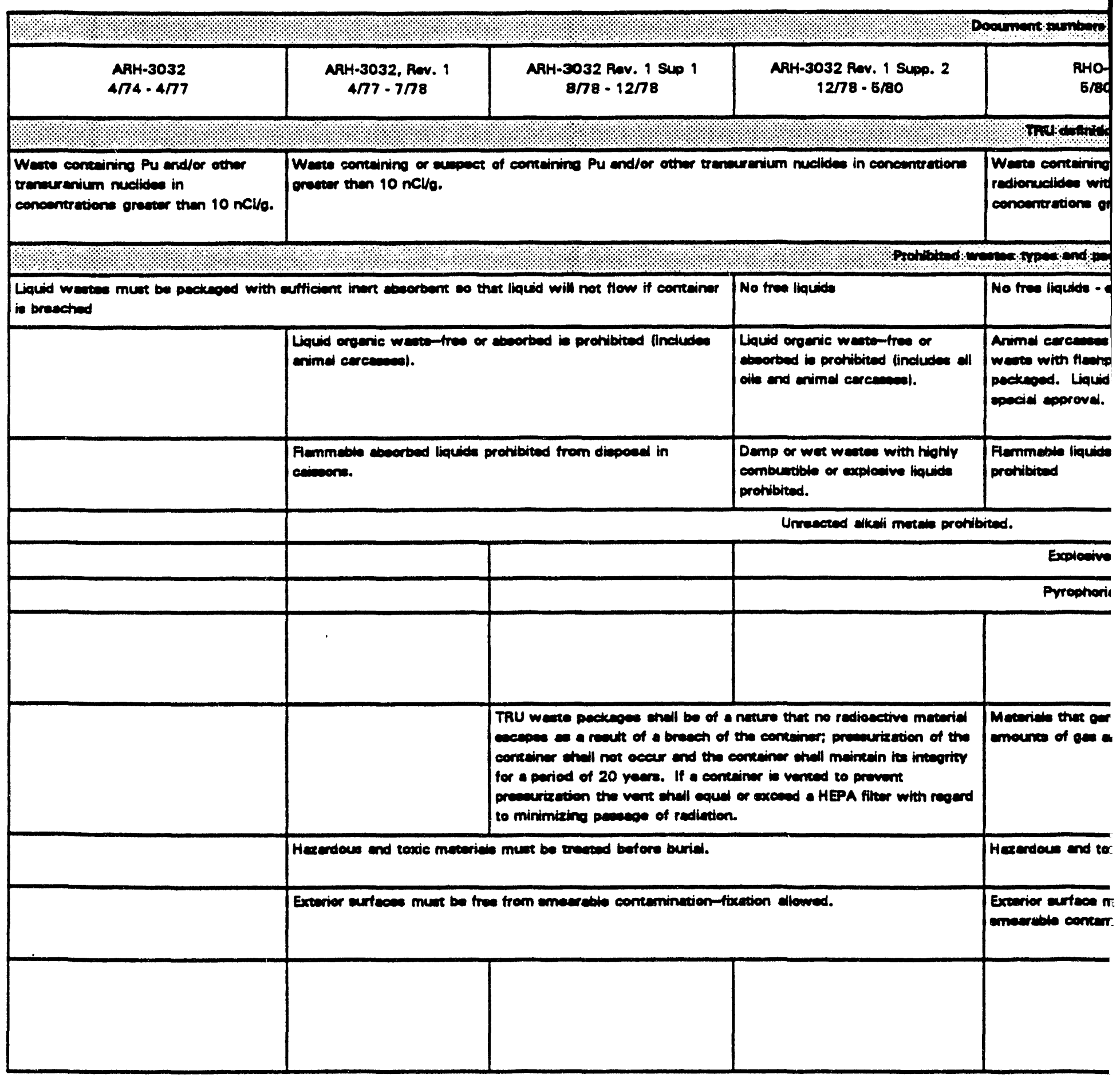


Table 4-1. Transuranic Storage Requirements for the Hanford Site. (3 sheets)

\begin{tabular}{|c|c|c|c|c|}
\hline $\begin{array}{l}14-222 \\
-8 / 82\end{array}$ & $\begin{array}{l}\text { RHO-A1A-222 } \\
\text { O/82 Revieion } \\
\text { G/82- G/83 }\end{array}$ & $\begin{array}{c}\text { RHO-MA-222 ROV } 1 \\
\text { G/B3 - 3/84 }\end{array}$ & $\begin{array}{l}\text { RHO-MA.222 Rav. } 1 \\
\text { 3/84. } 7 / 84\end{array}$ & $\begin{array}{l}\text { RHOAMA-222, Rav. } 2 \\
\text { 7/84 } \cdot 8 / 85 \cdot\end{array}$ \\
\hline \multicolumn{5}{|l|}{4} \\
\hline \multicolumn{2}{|c|}{ 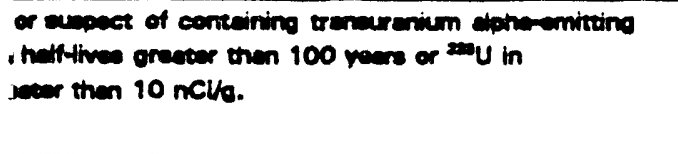 } & Doameme Unovellebio & \multicolumn{2}{|c|}{ 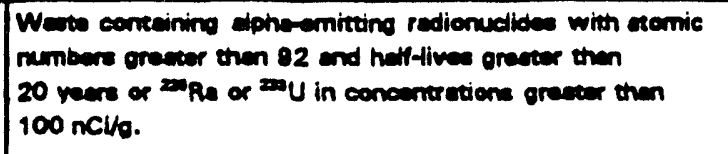 } \\
\hline \multicolumn{5}{|c|}{ Hinerequnnest } \\
\hline \multicolumn{2}{|c|}{ reapt liavid oroenic werese. } & & $\begin{array}{l}\text { No tres liquide - axcept lialid } \\
\text { oreanic westes }\end{array}$ & No trea liaquide \\
\hline \multicolumn{2}{|c|}{ 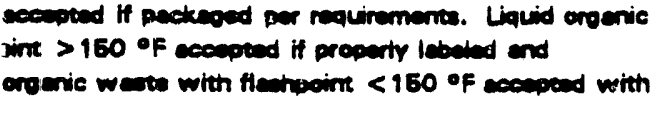 } & & \multicolumn{2}{|c|}{ 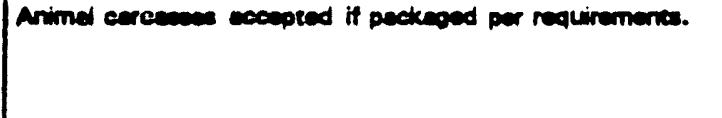 } \\
\hline \multicolumn{2}{|c|}{ tree or abortbed with flempoims below 160 of } & & \multicolumn{2}{|c|}{ Shedoes cennot contein tree liquide. } \\
\hline & & & \multicolumn{2}{|c|}{ 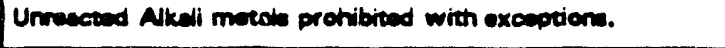 } \\
\hline \multicolumn{2}{|l|}{ Pronibiead } & & \multirow{2}{*}{ 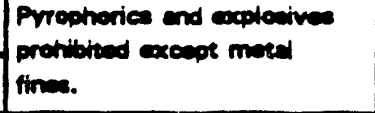 } & Explocive prohibited. \\
\hline \multicolumn{2}{|l|}{ I prochibitiod } & & & Prrophorice prohibitied. \\
\hline & & · & 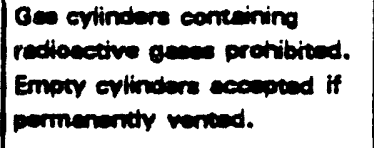 & $\begin{array}{l}\text { Compreaned anow } \\
\text { prohtbitied. }\end{array}$ \\
\hline $\begin{array}{l}\text { rese sionifieant } \\
\text { i prentitiod. }\end{array}$ & 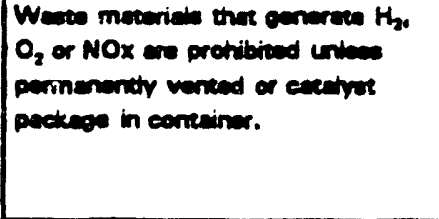 & & 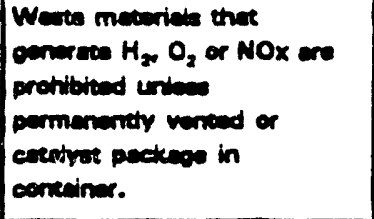 & 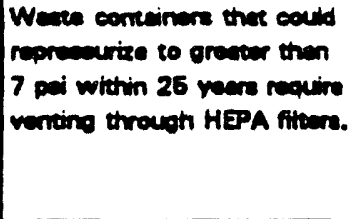 \\
\hline \multicolumn{2}{|c|}{ 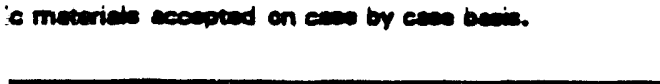 } & & \multicolumn{2}{|c|}{ 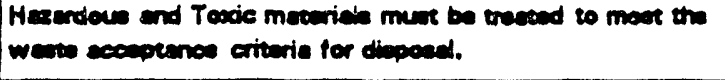 } \\
\hline \multirow[t]{2}{*}{$\begin{array}{l}\text { We tres from } \\
\text { wien. }\end{array}$} & 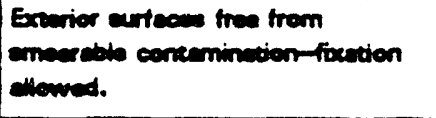 & & 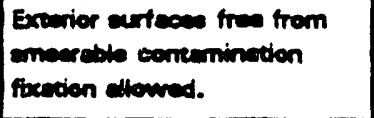 & 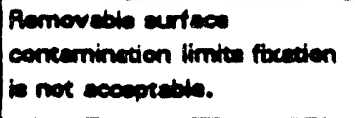 \\
\hline & & & & 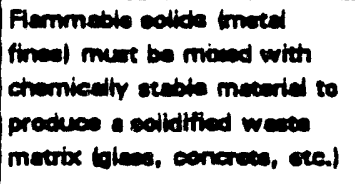 \\
\hline
\end{tabular}




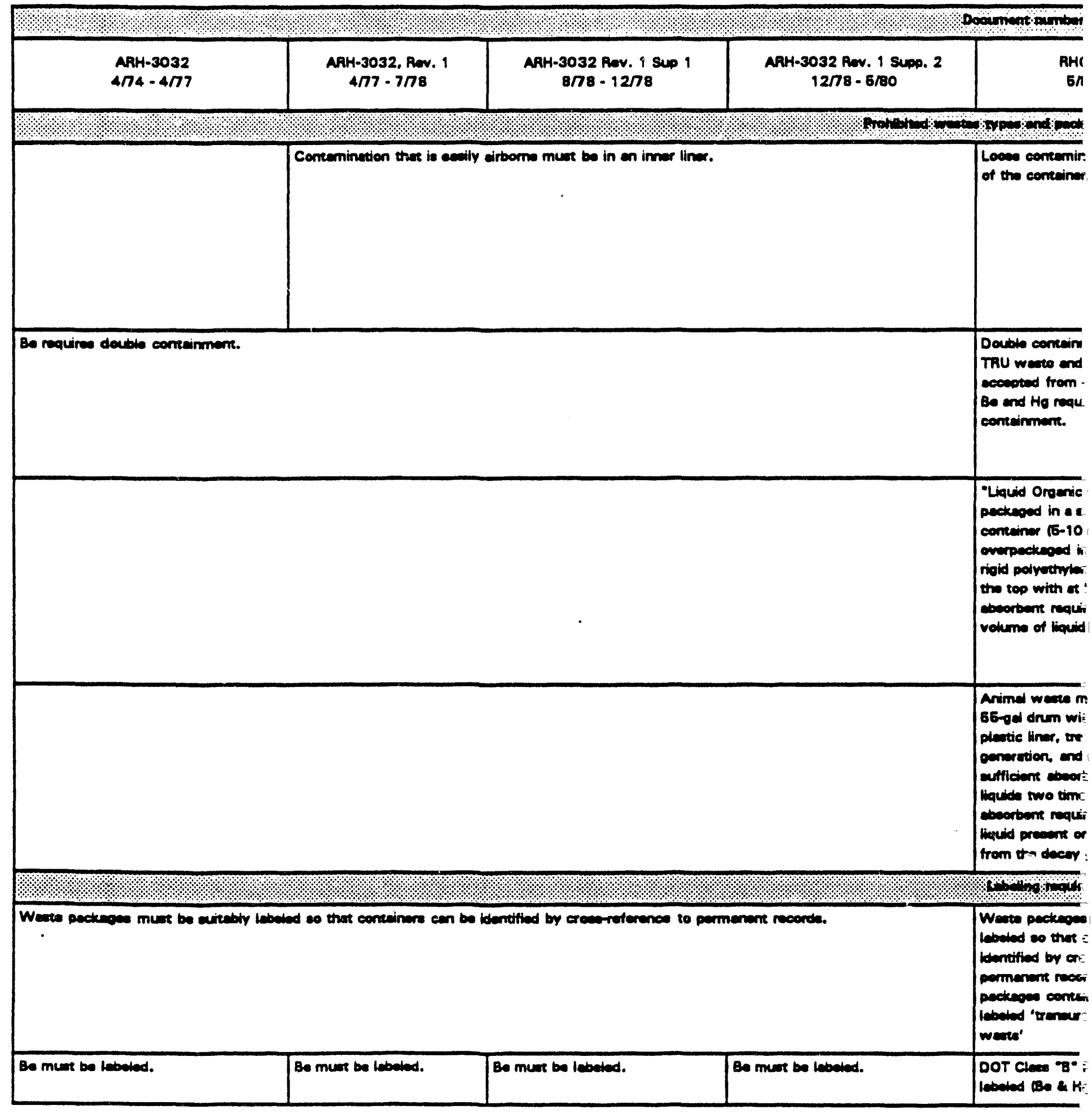


WHC-EP-0719

Table 4-1. Transuranic Storage Requirements for the Hanford Site. (3 sheets)

\begin{tabular}{|c|c|c|c|c|}
\hline $\begin{array}{l}\text { MA-222 } \\
3.0 / 122\end{array}$ & $\begin{array}{l}\text { AHO-MA-222 } \\
\text { O/B2 Rovivion } \\
\text { O/B2 - } 9 / 83\end{array}$ & $\begin{array}{c}\text { AHO-MA-222 Rav } 1 \\
\text { O/83 - 3/84 }\end{array}$ & $\begin{array}{c}\text { RHO-MA-222 Rav. } 1 \\
3 / B 4=7 / 84\end{array}$ & $\begin{array}{c}\text { AHOMAA222, Rev. } 2 \\
\text { 7/84 - 8/86 }\end{array}$ \\
\hline
\end{tabular}

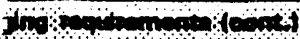

ion murt be etabilbed or centeined so thet the arfees

remeins the of detweteble loces contemineder.

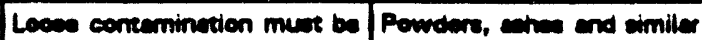
rembilized of conteined so the the eurfece of the cenceiner remain tree of dotectable loow pertieulace muex be immabilized in conenets. olese or vimile colidified comeminotion.

matrix if $>1$ weight $x$ of th metrix weight is perdiculeces

$<10$ mierons in diemover or if $>16$ wiokt $x$ is $<200$ microns in diemecex.

Ine requined for ell ar ell were hite ementers. id doutive
Doute centerinmente required for eff ThU were. Double cerreinment is requind for Cd and Ho. Be, Cd, and to muxt be peckend with at hert $0^{\circ}$ of concrues on ell dides.
Double cerreinment required for ell TRU werte. Doutie coneinmert is requind for Cd and Ho. Be, Cd, and Ho muxt be packeced with at bex $8^{\circ}$ of conerute on ell aide.

"Liquid Oromic were mut be pectenoed unebertied in a realed liquidtiont conciner 15-10 oellonl, owerpectecesd in 65-od drum with a rioid potyouryione lines and filled to the tep with et hant two

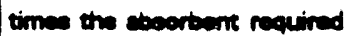
to entert the velume of fiepind in the conteiner.

Animel wate mut be pectend in a 65od drum whe

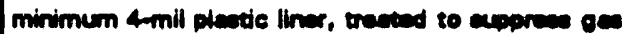
genuration, and eurrounded by nwo times amours of aberbent required to beerb eny liavid prevert or thet mey react frem the decery procens.
Dewtiv centeinmam requined for all TRU werte. Be, Cd, Ha and other den $B$ peicen muet be immobilined in cenerve for berid.

Lapid eroenie werte must be coliditived for sterece or divoced. Exception or cendidered on a ease by cene bens.

trwe times the

1 the cerreninar.

dive repith et lent two tim

the velume of liquid in the centeinore.

$x$ be peckesed in a Animel wase mut be peckeond in

- minimum 4-mil a 56 -ad drum with a minimum

d to uppreas oes 4 mill plactie liner, trecoud to

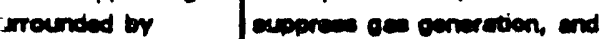

it to prowert the ceurrounded by two timos the

the encunt of

1 to chert en

het mey nout

coenes.

ameane of cheorbent rapined to

cheort eny lavid promen or thet

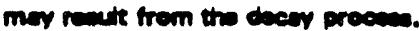

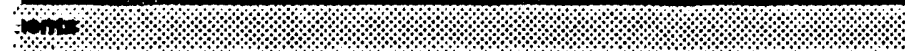

mexe be artedy

reinere en be

Mivierence to

B. Weate

in Thu munt bo

je or 'tromereric

ichind so thet conerinere en by

identified by eresernterence to

mermerion recode.

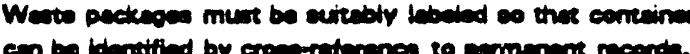

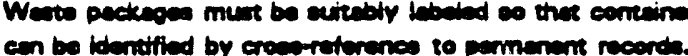

(




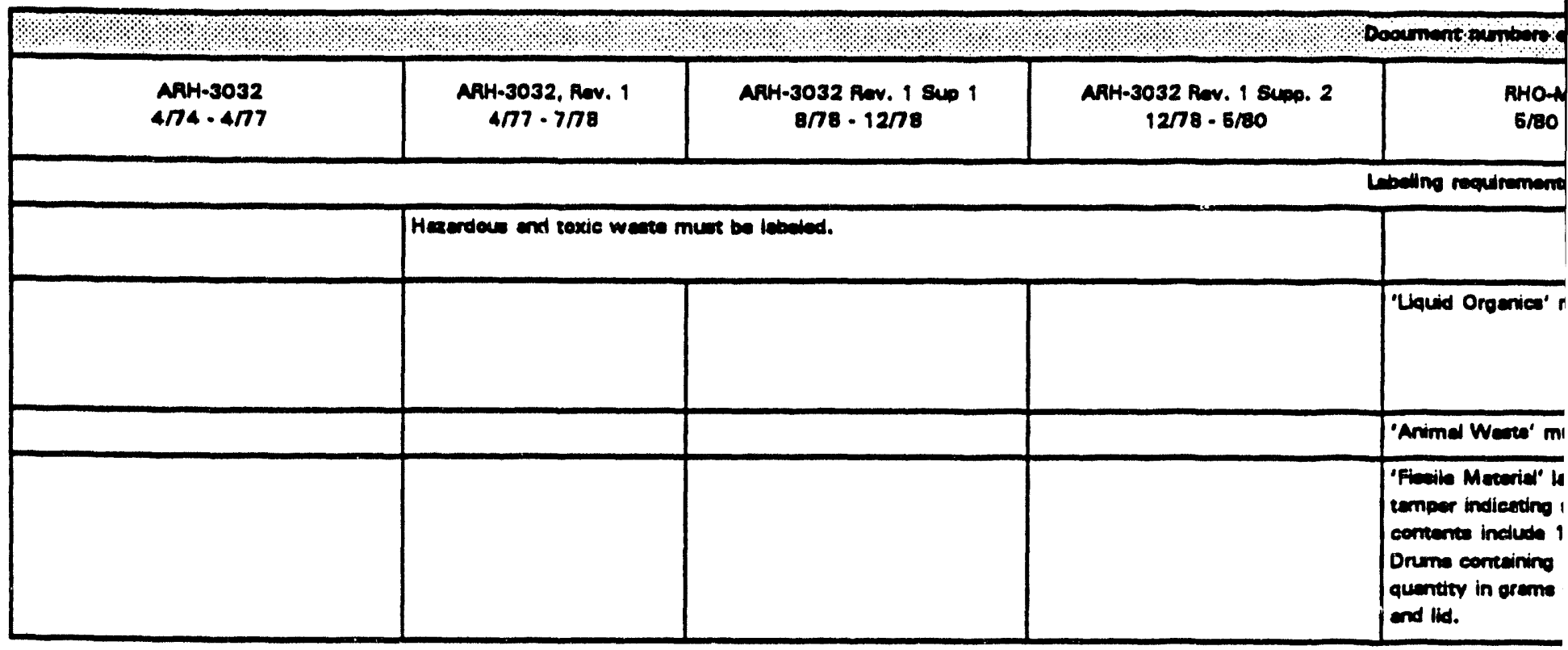

NOTE: For the peried of 1970 through April 1974, document mumbere ere unknewn.

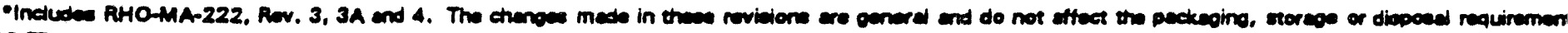
WMC-EP-0082, Rew. 0 MMllie and Triner 19811.

DOT - U.S. Deperament of Traneortedion.

HEPA - Hion Efficionoy Pertialete Air.

ThU - Tranmeric 
Table 4-1. Transuranic Storage Requirements for the Hanford Site. (3 sheets)

\begin{tabular}{|c|c|c|c|}
\hline $\begin{array}{l}4222 \\
8 / 22\end{array}$ & 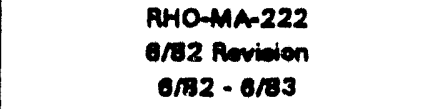 & $\begin{array}{c}\text { RHOMA-222 RaV } 1 \\
\text { E/83 } \cdot 3 / 84\end{array}$ & $\begin{array}{l}\text { RHO-MA-222, Rev, } 2 \\
\text { 7/84 - 8/86* }\end{array}$ \\
\hline \multicolumn{4}{|l|}{ (eone) } \\
\hline & 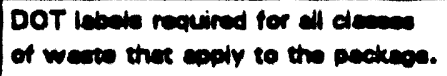 & & 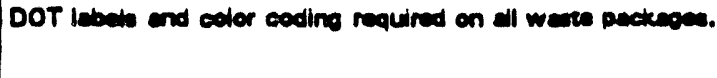 \\
\hline Ant be labeded. & 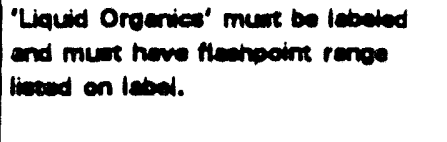 & & 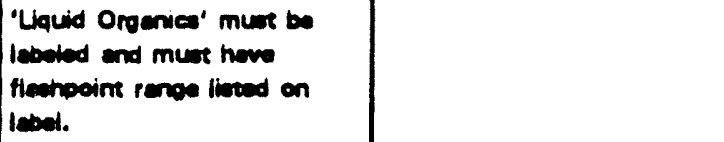 \\
\hline It be Inbied & 'Animel Wenes' mux be tebaled. & & 'Animed Weste' must be laband. \\
\hline 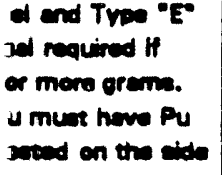 & 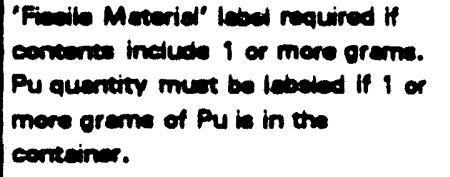 & & 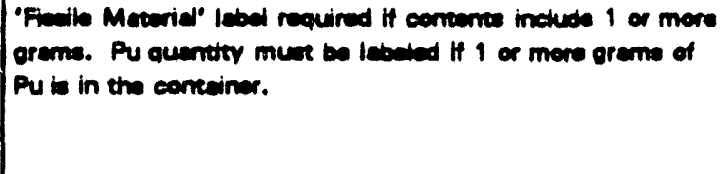 \\
\hline
\end{tabular}

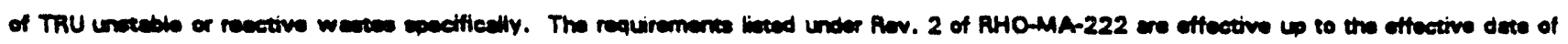


WHC-EP-0719

\subsection{CHARACTERIZATION OF RETRIEVABLY STORED SOLID WASTE GENERATED BY BABCOCK AND WILCOX}

The TRU waste sent from Babcock and Wilcox's Plutonium Facility to retrievable storage at the Hanford Site was generated as the result of fuel pin fabrication for FFTF cores $1,2,3$, and 4 and the subsequent decontamination and cleanout of the Facility. Fuel pin fabrication for cores 1 and 2 took place roughly from 1972 through 1975 while fuel pin fabrication for cores 3 and 4 took place from 1975 through 1979.

Decontamination and cleanout of the Plutonium Facility spanned the years from 1980 through 1983.

The information in this section is based on data available at the Hanford Site about the TRU wastes shipped from Babcock and Wilcox. This information is based primarily on data from the SWITS database. This database, which incorporated the older R-SWIMS database, is used to track information on radioactive and other wastes stored or disposed at the Hanford Site. Radioactive solid waste packages have been tracked since 1970. In the intervening years, changes in the requirements and regulations governing radioactive wastes have left their mark in the quantity and quality of the data tracked in this database. Caveats are included in the text to alert the reader to changes that may affect the interpretation of the data provided. The original SWITS data that form the basis for most of the tables and figures in this section are in Appendix A. Each computer run is preceded by the query used to generate the data.

Unfortunately, before 1981, waste from Babcock and Wilcox was attributed to other buildings (i.e., 234-5Z, 325, 340) in the SWITS database. It is likely that this is because of custody changes from Babcock and Wilcox to HEDL before onsite assay and retrievable storage of the waste. A thorough search of burial records, shipping and receiving logs, nuclear accountability forms, and other pertinent documentation was conducted in an attempt to Incate Babcock and Wilcox containers that had been attributed to Hanford Site facilities. Appendix B contains a summary table of the data taken from SWBRs for the Babcock and Wilcox containers that were located. This summary table is not complete as records for the containers believed to have been shipped to the Hanford Site before 1978 have yet to be located. The data for Babcock and Wilcox containers that were redesignated as coming from an onsite facility have been added to the tables and figures in this section to make them as complete as possible. Because not all the records for containers shipped from Babcock and Wilcox have been located, the data in this search represent the minimum numbers of Babcock and Wilcox containers that are present in the solid waste burial grounds.

\subsection{SUMMARY OF BABCOCK AND WILCOX WASTE GENERATION}

Table 5-1 presents TRU waste generation summaries by container type and year. Waste containers listed for the years 1977 through 1979 resulted from fuel pin fabrication for FFTF cores 3 and 4. Containers listed from 1981 through 1983 were generated as a result of decontamination and cleanout of the Plutonium Facility. Since the initial retrieval efforts and WRAP 1 will focus on 55-gal drums, these containers are considered 
separately from all other container types. Therefore, the term 'other containers' in this report will refer to all container types, except 55-gal drums, combined. The term 'drum' refers to 55-gal drums only.

\subsubsection{Waste Stored in 55-Gallon Steel Drums}

The most common waste container for TRU waste stored at the Hanford Site is the 55-gal steel drum. The drums used are either DOT 17C or 17H produced from carbon sheet steel with minimum wall thicknesses of $.135 \mathrm{~cm}$ (.053 in.) and $.109 \mathrm{~cm}(.043 \mathrm{in}$.$) ,$ respectively. Before 1982, many of the drums used were painted, so these drums have approximately $.013 \mathrm{~cm}(.005 \mathrm{in.})$ of paint on both the exterior and interior of the drums. In 1982, galvanized drums replaced painted drums. Recycled 55-gal drums also were permitted for the storage of TRU waste between 1973 and 1978.

The 1970 Immediate Action Directive (AEC 1970) stipulated that TRU wastes be packaged and stored as contamination-free packages for at least 20 years. The 20 -year interim period was to allow time to study permanent disposal options for TRU contaminated wastes. As more of the 55-gal drums reach and exceed the 20-year storage mark, more attention has been given to ascertaining the condition of these drums.

A discussion of the previous studies of steel drum corrosion and degradation can be found in WHC-0225, Rev. 1 (Anderson et al. 1991) and WHC-SA-1450-FP (Duncan et al. 1992).

Table 5-2 contains waste summary data for 55-gal drums of radioactive waste generated at Babcock and Wilcox and sent to retrievable storage at the Hanford Site between 1977 and 1983. This table indicates the number, total weight, and total volume of TRU and TRU-mixed-waste drums. Figures 5-1 through 5-3 present this information graphically.

5.1.1.1 Number of Drums. Between 1977 and 1983, 1451 55-gal drums of radioactive waste were generated at Babcock and Wilcox and sent to retrievable storage at the Hanford Site. This includes one radioactive-mixed-waste drum. Figure 5-1 provides a graph of the number of 55-gal drums of TRU generated at Babcock and Wilcox by year. The peak in 1981 is the result of the repackaging of existing wastes during the early cleanout activities.

5.1.1.2 Weight. Between 1977 and 1983 , approximately $104,242 \mathrm{~kg}(229,810 \mathrm{lb})$ of TRU waste was generated at Babcock and Wilcox and stored in 55-gal drums. The lightest mean weight per drum was found in 1979 with a mean weight/drum of $46 \mathrm{~kg}$ (101 lb). The heaviest mean weight per drum, $89 \mathrm{~kg}(196 \mathrm{lb})$, was found in 1982.

Figure 5-2 presents a graph depicting the total weight of TRU radioactive wastes stored annually in 55-gal drums.

5.1.1.3 Volume. The total volume of TRU waste generated at Babcock and Wilcox and stored in 55-gal drums is $303.2 \mathrm{~m}^{3}\left(10,707.3 \mathrm{ft}^{3}\right)$. The volume of TRU waste generated between 1977 and 1983 at Babcock and Wilcox and stored in 55-gal drums is shown graphically in Figure 5-3. All 55-gallon drums have a volume of .21 $\mathrm{m}^{3}\left(X \mathrm{ft}^{3}\right)$. 


\subsubsection{Waste Stored in Containers Other Than 55-Gallon Stoel Drums}

Radioactive solid wastes have been stored or disposed of in a wide variety of containers other than 55-gal steel drums. In this discussion these containers will be referred to as 'other containers.' Container types used for solid waste generated at Babcock and Wilcox and stored at the Hanford Site include portable tanks and metal boxes, cartons, and cases.

Table 5-3 summarizes the waste data for containers of radioactive waste other than 55-gal drums that were generated at Babcock and Wilcox and sent to retrievable storage at the Hanford Site between 1977 and 1983. This table indicates the number, totel weight, and total volume of TRU waste stored in other containers.

5.1.2.1 Number of Other Containers. Between 1981 and 1983, 26 other containers of radioactive TRU waste were generated at Babcock and Wilcox for storage at the Hanford Site. Figure 5-4 is a graph of the number of other containers of TRU generated at Babcock and Wilcox for storage at the Hanford Site by year.

The largest number of other containers containing TRU waste was generated in 1982 with 23 containers. Note that 55 -gal drums were the only waste containers found from before 1982.

5.1.2.2 Woight. In 1982 and 1983, approximately $72,351 \mathrm{~kg}(159,504 \mathrm{lb})$ of radioactive solid TRU waste was generated at Babcock and Wilcox and placed in containers other than 55-gal drums for storage at the Hanford Site. In 1982 other waste containers averaged $2,768 \mathrm{~kg}(6,102 \mathrm{lb})$ each; in 1983 they averaged $2,897 \mathrm{~kg}(6,387 \mathrm{lb})$ each. Figure 5-5 depicts the weight of TRU waste stored in containers other than 55-gal drums on an annual basis.

5.1.2.3 Volume. The volume of TRU waste generated at Babcock and Wilcox and packaged in containers other than 55-gal drums for storage at the Hanford Site in 1982 and 1983 is $140.4 \mathrm{~m}^{3}\left(\times 4,958 \mathrm{ft}^{3}\right)$. Figure 5-6 shows annual volumes of TRU waste generated and packaged in containers other than 55-gal drums.

\subsubsection{Summary of Waste Ceneration Rates at Babcock and Wilcox Between 1977 and 1983}

5.1.3.1 Number of Waste Containers. Between 1977 and 1983; there were 1,477 containers of radioactive solid waste generated at Babcock and Wilcox. Fifty-five-gallon drums account for 98 percent of this total; other containers account for the remaining 2 percent. Section 5.2, describes the container types used in greater detail. Figure 5-7 is a graph of the total number of TRU waste containers generated at Babcock and Wilcox on an annual basis during this period.

5.1.3.2 Total Weight. Over $176,593 \mathrm{~kg}(389,314 \mathrm{lb})$ of the radioactive solid waste stored at the Hanford Site was generated at Babcock and Wilcox between 1977 and 1983. Waste packaged in 55-gal drums accounts for about 59 percent of the total weight of waste from Babcock and Wilcox; 41 percent of the total weight comprised waste 
packaged in some other type of waste container. Figure 5-8 provides a graph of the total weight of TRU waste generated at Babcock and Wilcox yearly between 1977 and 1983.

5.1.3.3 Total Volume. Between 1977 and $1983,443.6 \mathrm{~m}^{3}\left(15,665 \mathrm{ft}^{3}\right)$ of the radicactive solid wastes stored at the Hanford Site were generated at Babcock and Wilcox. Sixty-eight percent of this volume comprised 55-gal drums; the remaining 32 percent of the volume is made up of other container types. Figure 5-9 shows the total volurne of TRU generated at Babcock and Wilcox for 1977 through 1983.

\subsection{WASTE CONTAINERS}

Table 5-1 provides a summary of the TRU waste generated annually at Babcock and Wilcox from 1977 to 1983 , sorted by container type. Fifty-five gallon metal drums, barrels, and kegs were the only container type used for the TRU waste before 1982.

In 1982 and 1983, other container types in addition to 55-gal drums also were used. Metal boxes, cartons, and cases were the most common containers used, accounting for more than 96 percent of the total TRU waste containers not packaged in 55-gal drums. The other storage container used for TRU waste was a portable tank. Figure 5-10 shows the tanks from Babcock and Wilcox emplaced on the asphalt pad in burial ground $4 \mathrm{C}$ on the right side of the photograph.

\subsection{TRANSURANIC WASTE STORAGE LOCATIONS}

Table 5-4 provides the storage location for TRU waste packaged in 55-gal drums by year. In 1978, drums from Babcock and Wilcox were stored in 218-W-4B. All the drums sent to the Hanford Site after 1978 were stored in a single location, 218-W-4C. The storage location for TRU waste packaged in other containers is also 218-W-4C, as shown in Table 5-5.

\subsection{PHYSICAL CONTENTS OF TRANSURANIC WASTE CONTANERS}

The physical contents for 55-gal drums of TRU waste stored in 218-W-4C are shown in Table 5-6. The top portion of the table indicates the number of drums for which a given component is listed; the bottom portion of the table indicates the percentage of the total drums that number represents. It should be noted that before 1978, physical contents were not required to be listed on the burial records, 80 a great many of the contents on early records are listed only as 'miscellaneous.'

The most commonly listed waste constituents for the drums generated by cores 3 and 4 work were filters. In 1979, filters were packaged in. 66 percent of the drums generated. In at least one-third of the drums generated in 1979, the following wastes were found:

- Cloth/rags/nylon

- Paper/cardboard 
- Plastic/polyurethane

- Wood/lumber/plywood.

During the decontamination and cleanout of the Plutonium Facility the main items on the drum physical contents lists included the following:

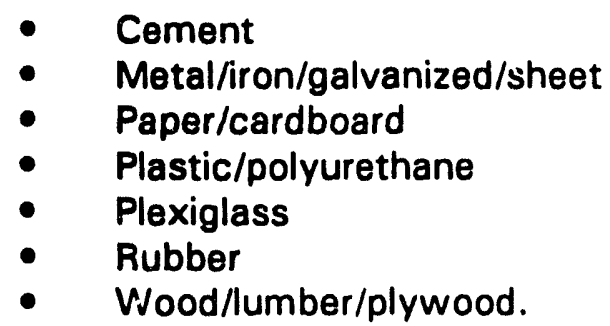

The physical contents for TRU waste containers other than 55-gal drums can be found in Table 5-7. All containers other than 55-gal drums contain metal/iron/galvanized/ sheet. Glass and cement also are common waste constituents in these containers.

\subsection{RADIOLOGICAL DESCRIPTION OF BABCOCK AND WILCOX SOLID WASTE}

Table 5-8 shows the number of TRU grams stored in 55-gal drums each year by storage location; Table 5-9 provides the same information for TRU containers other than 55-gal drums. Figure 5-11 combines the information on these tables in a graph that shows the total grams of TRU present in waste packages shipped to the Hanford Site from Babcock and Wilcox by year.

Burial records from Babcock and Wilcnx were searched for containers with greater than $175 \mathrm{~g}$ of TRU. Table 5-10 summarizes the data for the 55-gal drums with high gram loading, and Table 5-11 provides the same information for containers other than 55-gal drums. Three of the five heavily gram-loaded containers are spread over a period of several years, and, therefore, probably represent routinely generated containers with abnormally high gram loading. However, two containers were recorded on the same date in 1982. These heavily gram-loaded containers probably represent an anomaly, such as a spill or other random occurrence.

\subsection{RADIOACTIVE ISOTOPES PRESENT IN BABCOCK AND WILCOX SOLID WASTE}

Information on radioactive isotopes was obtained primarily from the SWITS database and the summary table in Appendix B. Listed below are isotopes known to be in the Babcock and Wilcox solid wastestream: 


\subsubsection{Plutonium}

The SWITS database shows Pu was contained in 773 burial containers in 1981; 246 containers in 1982; and 153 containers in 1983. The summary table lists 9 containers in 1977; 168 containers in 1978; and 127 containers in 1979.

\subsubsection{Uranium}

The SWITS database indicates the burial of 708 containers with natural uranium in 1981; 209 containers with depleted uranium in 1982; and 9 containers with depleted uranium in 1983.

\subsubsection{Americium}

The SWITS database has record of 21 containers with ${ }^{241}$ Am being buried in 1981; 136 containers in 1982; and 8 containers in 1983.

\subsection{HAZARDOUS CONSTITUENTS OF SOLID WASTE GENERATED BY BABCOCK AND WILCOX}

This section provides a review of the data on the hazardous components found in the SWITS database and on the original burial records. Because information on the nonradioactive, hazardous chemicals in waste containers was not required on burial records before 1987, information before that date could be incomplete.

\subsubsection{Solid Waste Information and Tracking System}

Information about hazardous constituents of the solid waste from Babcock and Wilcox could be incomplete because of the recording and tracking practices in the years before 1987. According to the SWITS database, only one drum from 1981 is designated as mixed waste accounting for $<1$ percent of the total drum count. This drum is stored in $218-W-4 C$ and is listed as containing beryllium.

\subsubsection{Burial Records}

The SWBR or SWSDR for a given container is the source of waste container information abstracted from the SWITS database. Often these records will have more detailed information on the hazardous components of a waste container than is found in SWITS. Additional data also can be found on the supplementary forms often attached to the SWBR or SWSDR. These supplementary documents include Uniform Hazardous Waste Manifests, Contents Inventory Sheets, NRC 741 Forms, and Storage/Disposal Approval Records (SDAR). 
A search of the microfilmed burial records indicated that beryllium was the only hazardous constituent listed among the solid waste sent from Babcock and Wilcox for storage at the Hanford Site. Table 5-12 contains a summary of the information obtained from the burial records.

\subsubsection{Interviews with Babcock and Wilcox Facility Personnel}

Personnel from Babcock and Wilcox indicated that the following hazardous constituents were used at the facility and are suspected in the waste sent for solid waste retrievable storage:

Mercury--Solidified with Fisher Scientific's Mercury Absorbent Powder

Resin--Dried, then solidified in concrete

Beryllium--If any beryllium is present it is probably left over from the source manufacturing days.

No organic solvents are likely to be found in waste packages because the presintering step in the process volatilized these compounds.

\subsubsection{Hazardous Constituent Used in Babcock and Wilcox Facility Process}

The following constituents were used in the fuel fabrication process for FFTF cores 1 and 2 and may or may not be present in the solid waste stream (Bradley and Clark 1978).

- Scrap Recovery Process

- Resins

- $\quad$ Nitric acid

- Hydrofluoric acid

- Sodium nitrite

- Other metal nitrites

- Analytical Chemistry Process

- $\quad$ Fuming sulfuric acid

- Phosphoric acid. 
WHC-EP-0719

This page intentionally left blank.

5-8 
Figure 5-1. Number of Transuranic Fifty-Five-Gallon Drums Shipped to the Hanford Site by Babcock and Wilcox by Year.

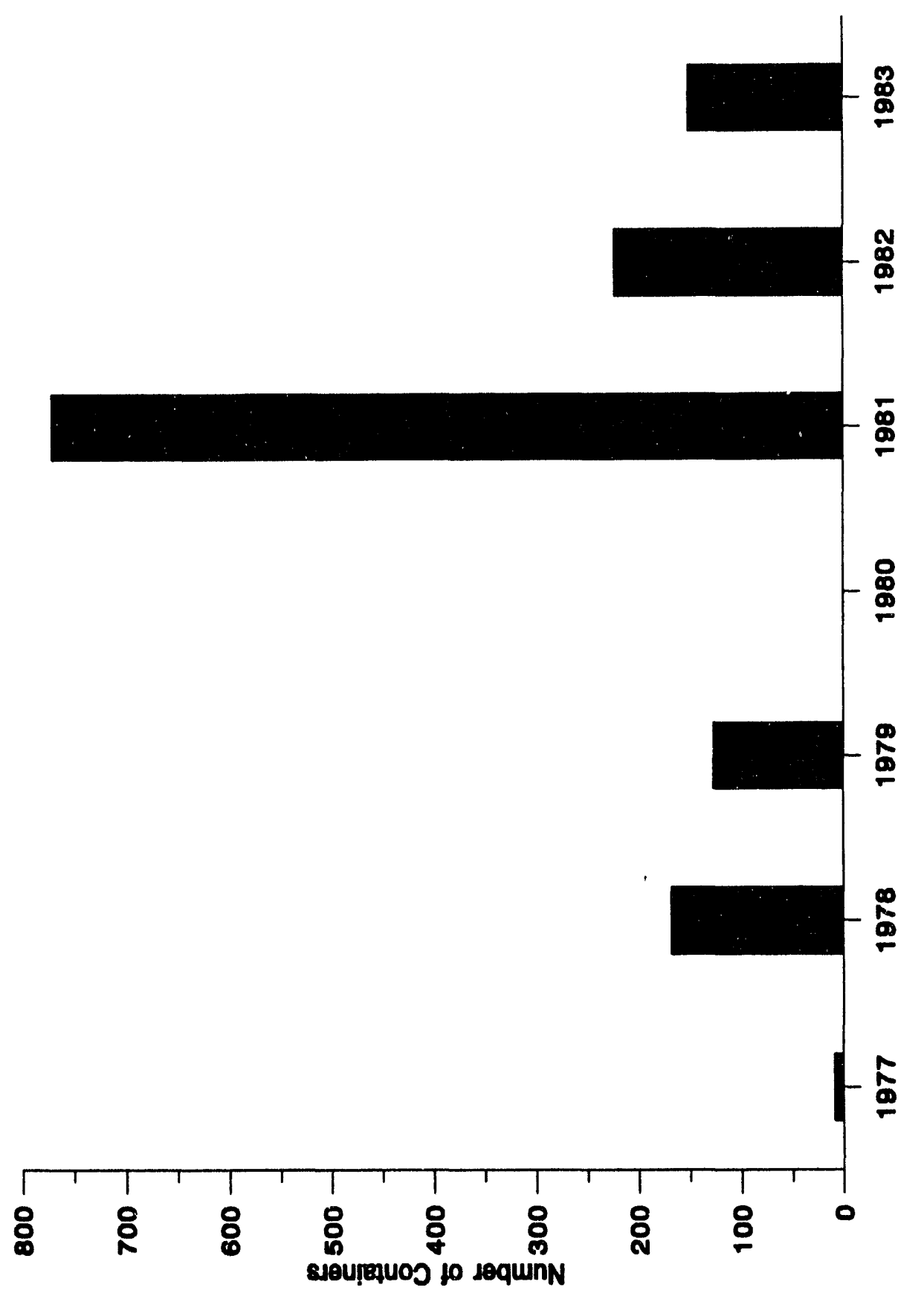


Figure 5-2. Weight of Transuranic Fifty-Five-Gallon Drums Shipped to the Hanford Site by Babcock and Wilcox by Year.

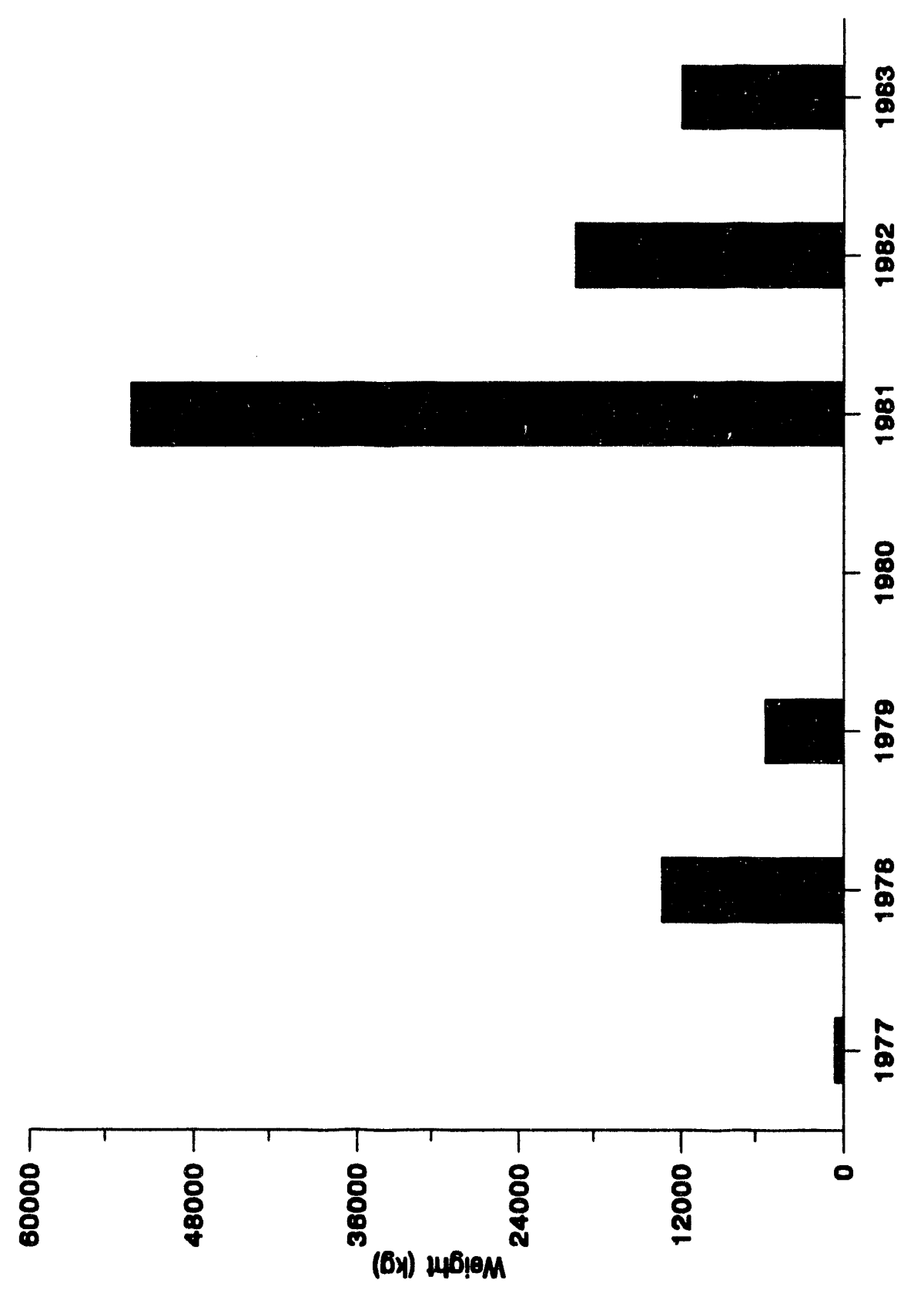


Figure 5-3. Volume of Transuranic Fifty-Five-Gallon Drums Shipped to the Hanford Site by Babcock and Wilcox by Year.

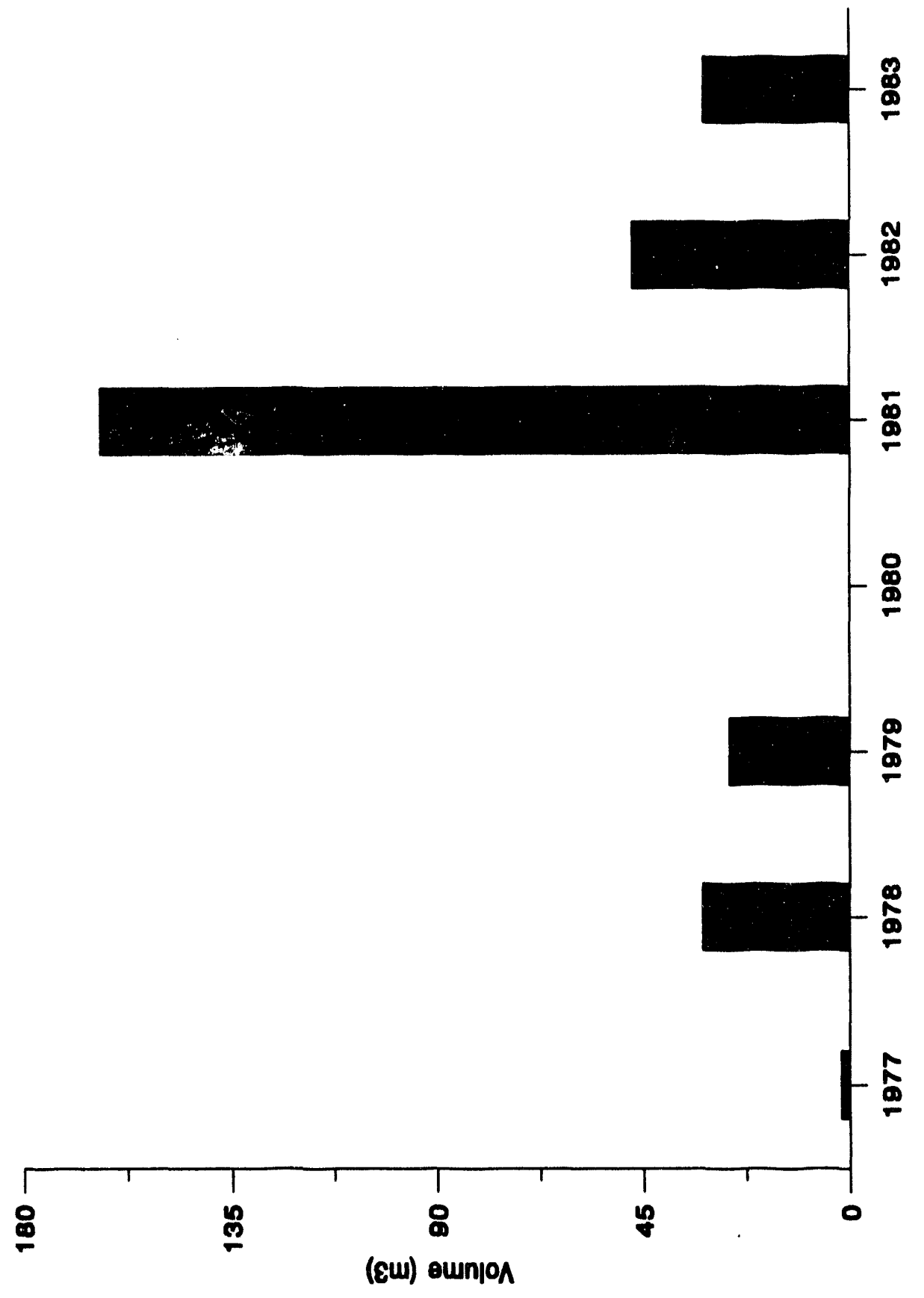


Figure 5-4. Number of Transuranic Other Containers Shipped to the Hanford Site by Babcock and Wilcox by Year.

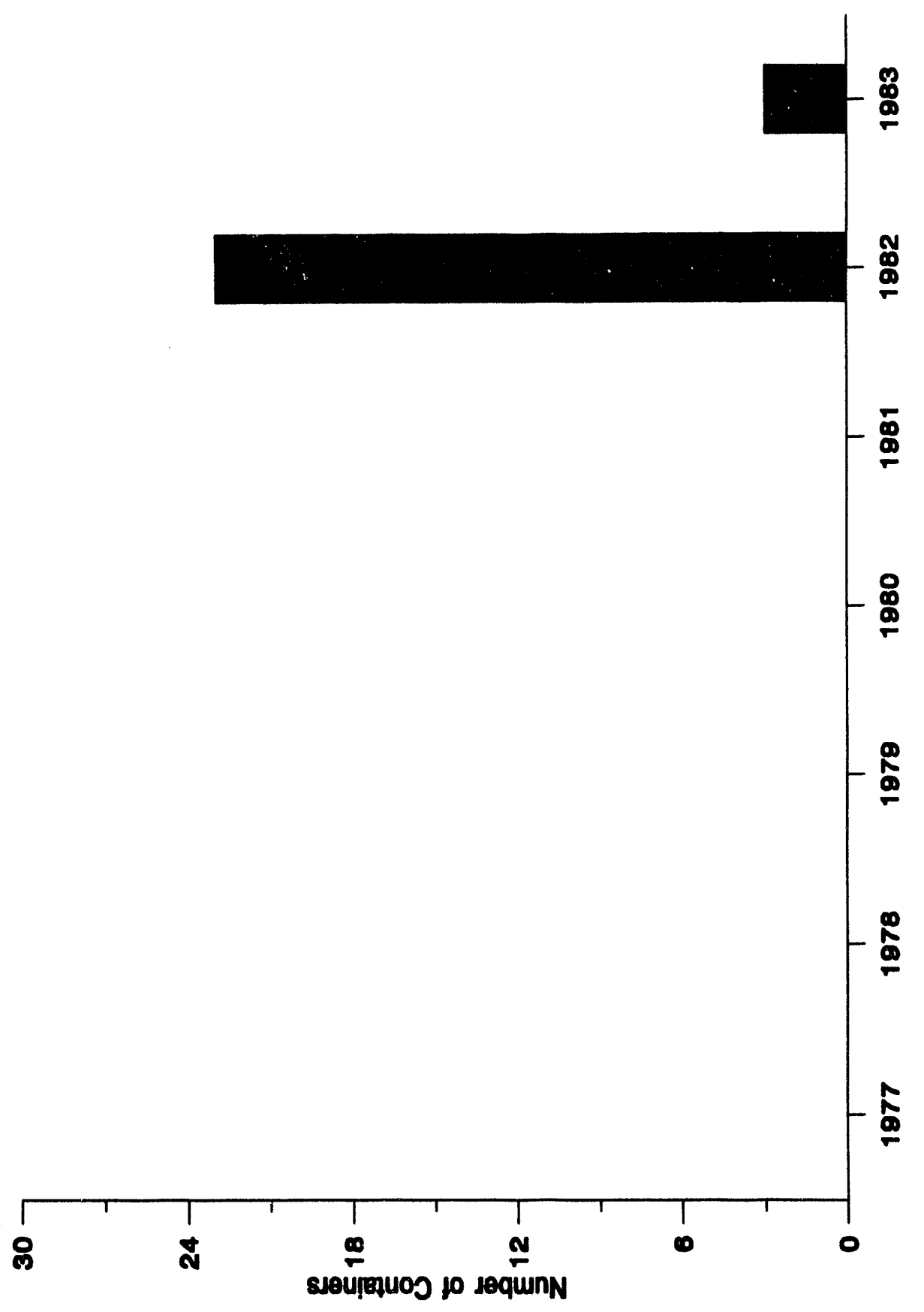


Figure 5-5. Weight of Transuranic Other Containers Shipped to the Hanford Site by Babcock and Wilcox by Year.

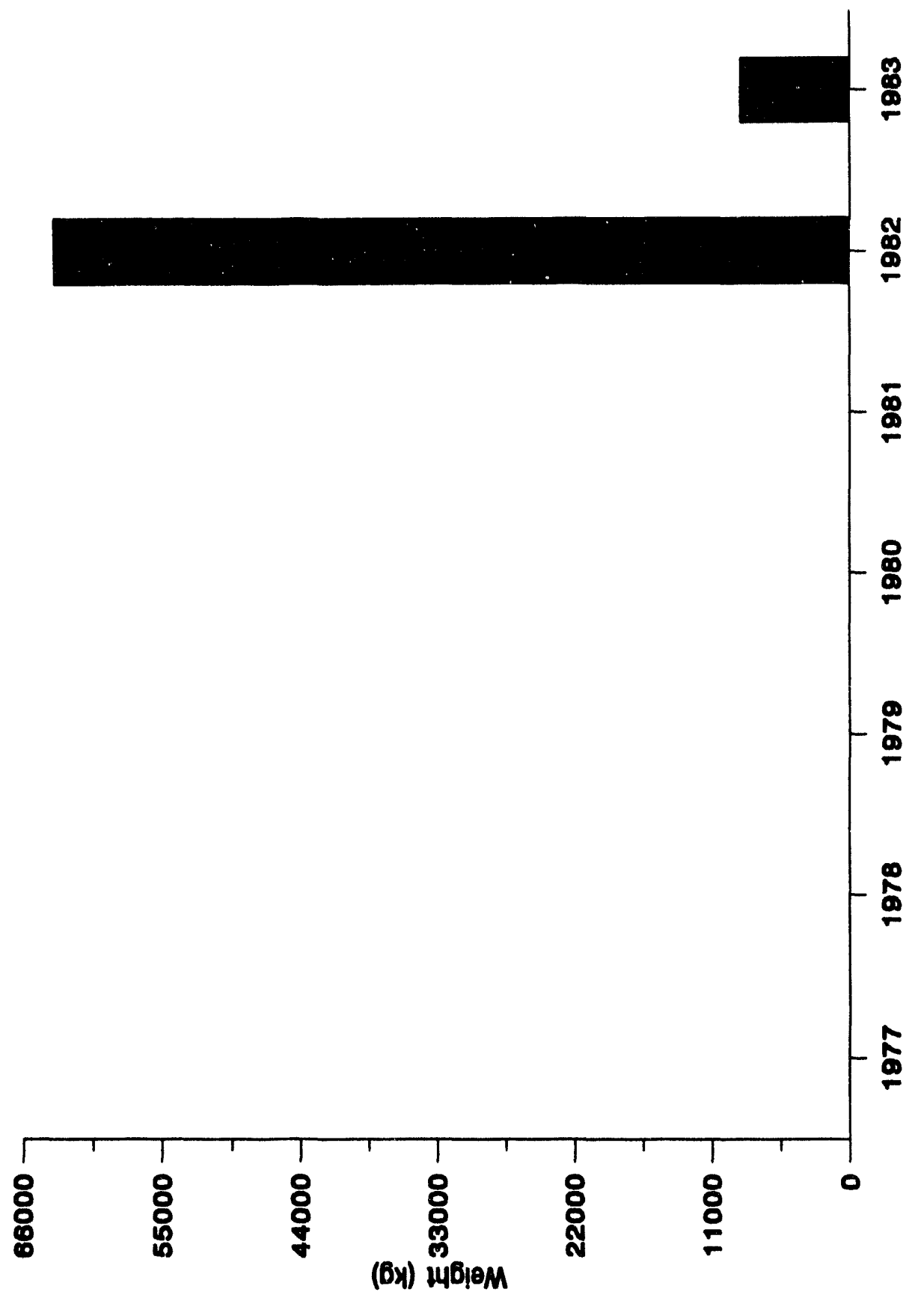


Figure 5-6. Volume of Transuranic Other Containers Shipped to the Hanford Site by Babcock and Wilcox by Year.

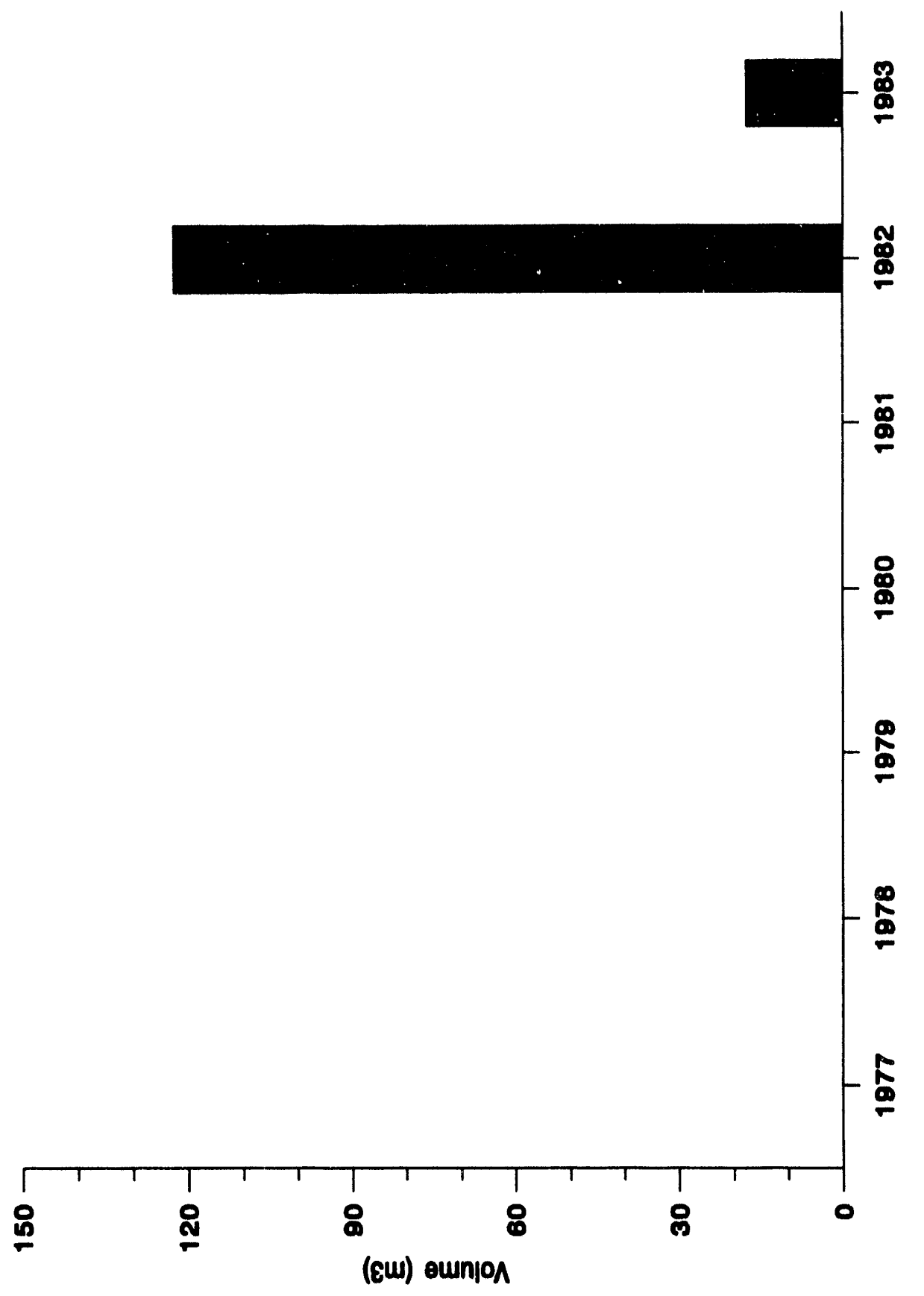


Figure 5-7. Total Number of Transuranic Waste Containers Shipped to the Hanford Site by Babcock and Wilcox by Year.

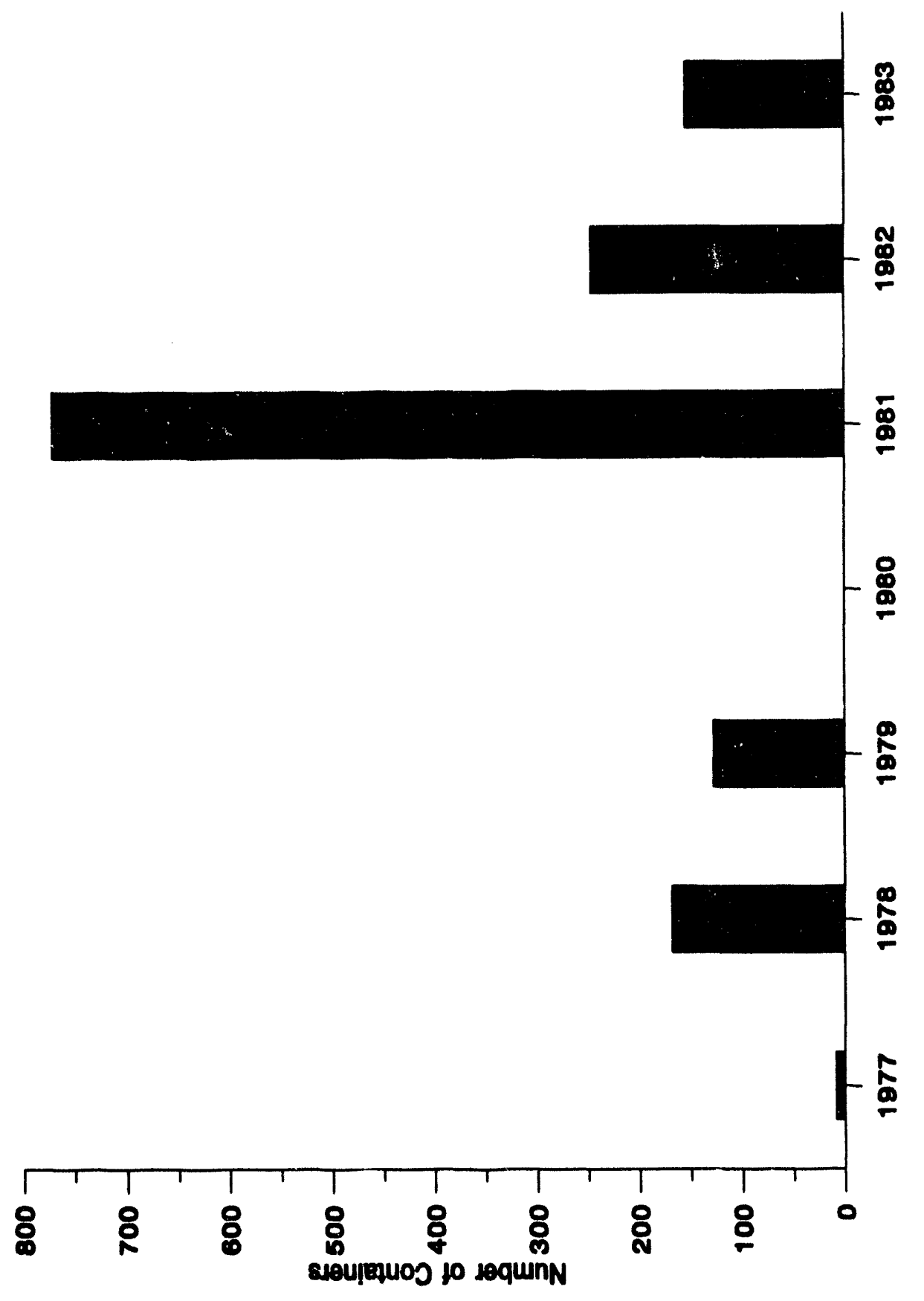


Figure 5-8. Total Weight of Transuranic Waste Containers Shipped to the Hanford Site by Babcock and Wilcox by Year.

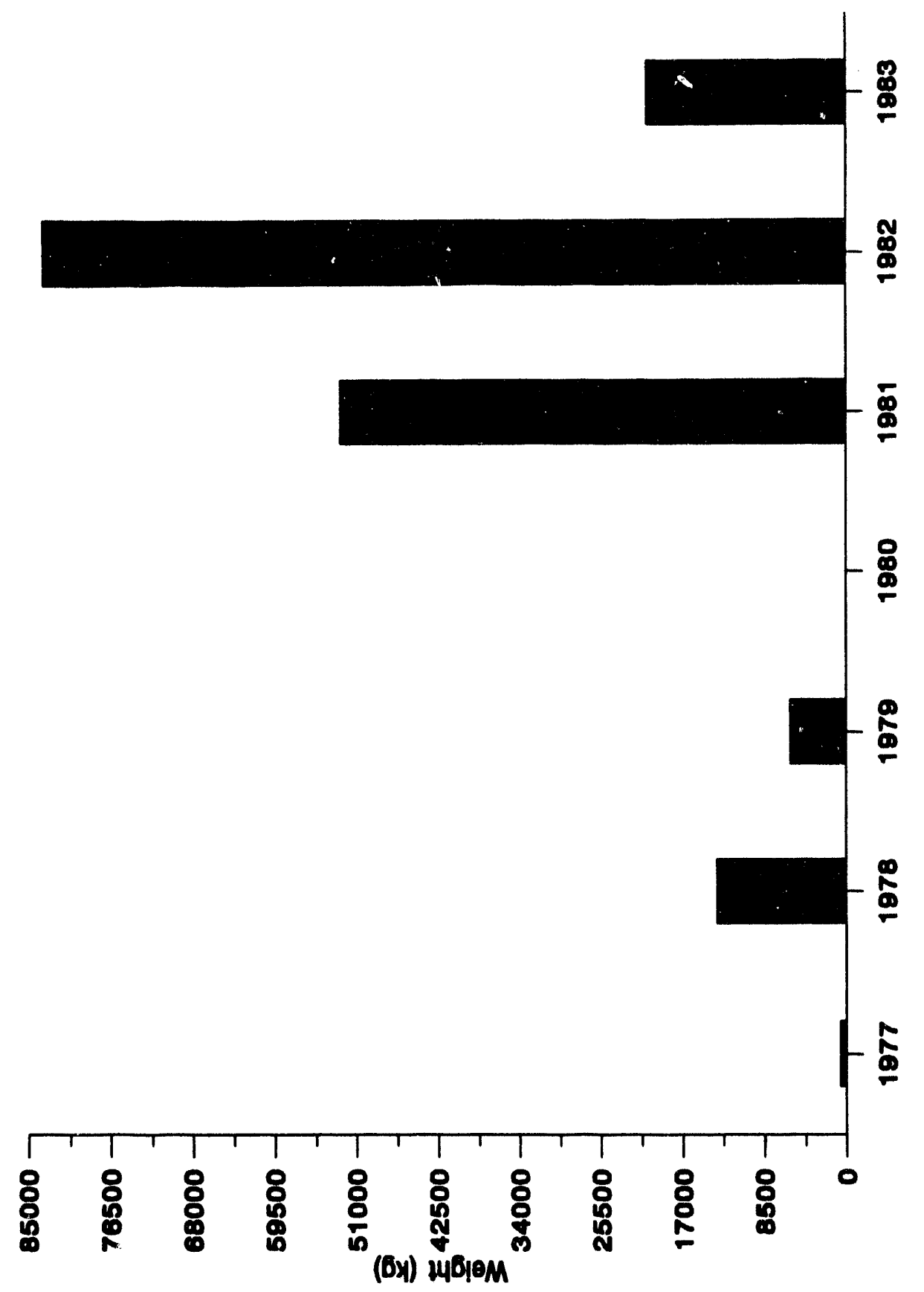


Figure 5-9. Total Volume of Transuranic Waste Containers Shipped to the Hanford Site by Babcock and Wilcox by Year.

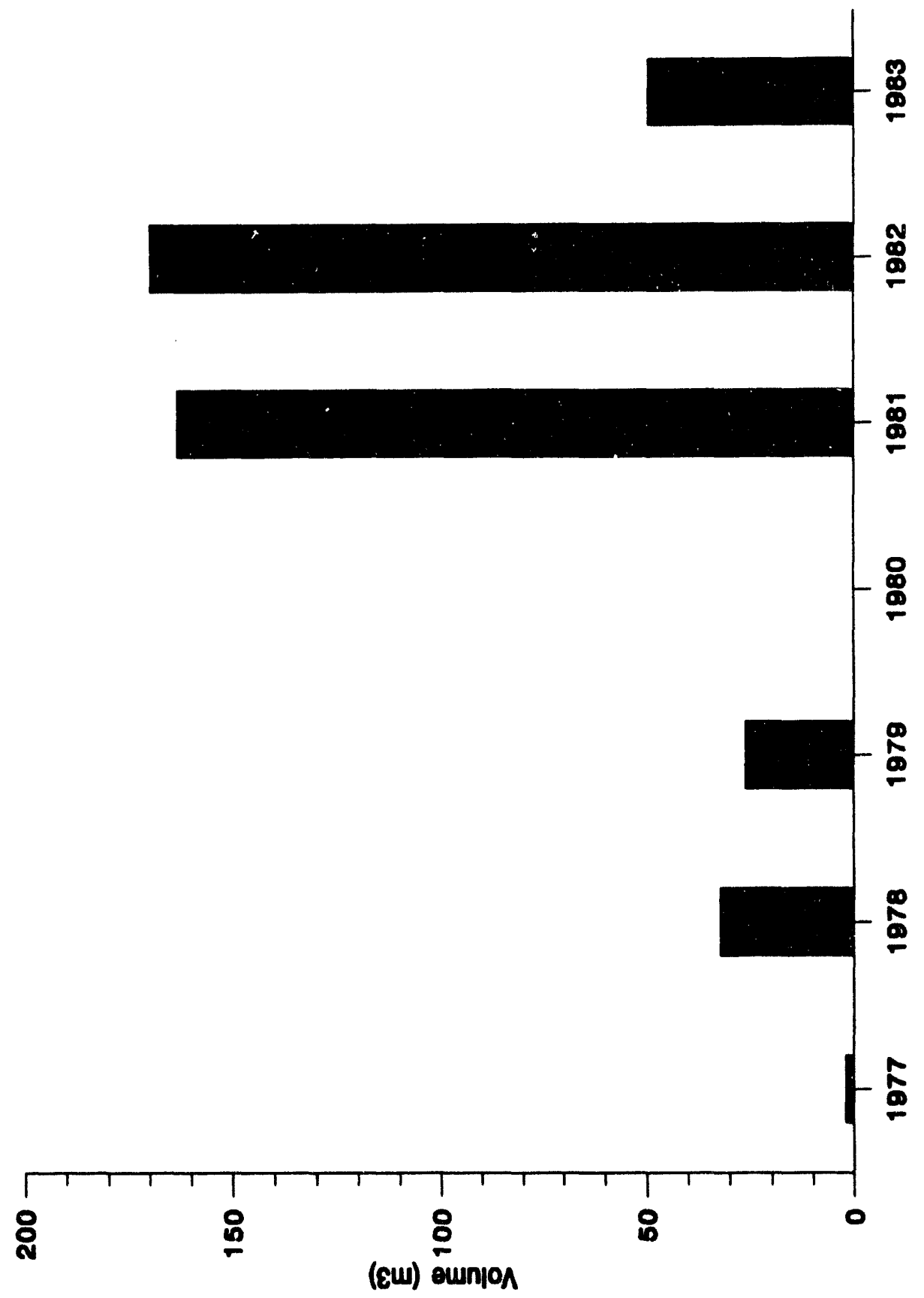


Figure 5-10. Metal Box Storage on Asphalt Pad Transuranic Retrievable Storage Burial Ground 4C 200 West Area.

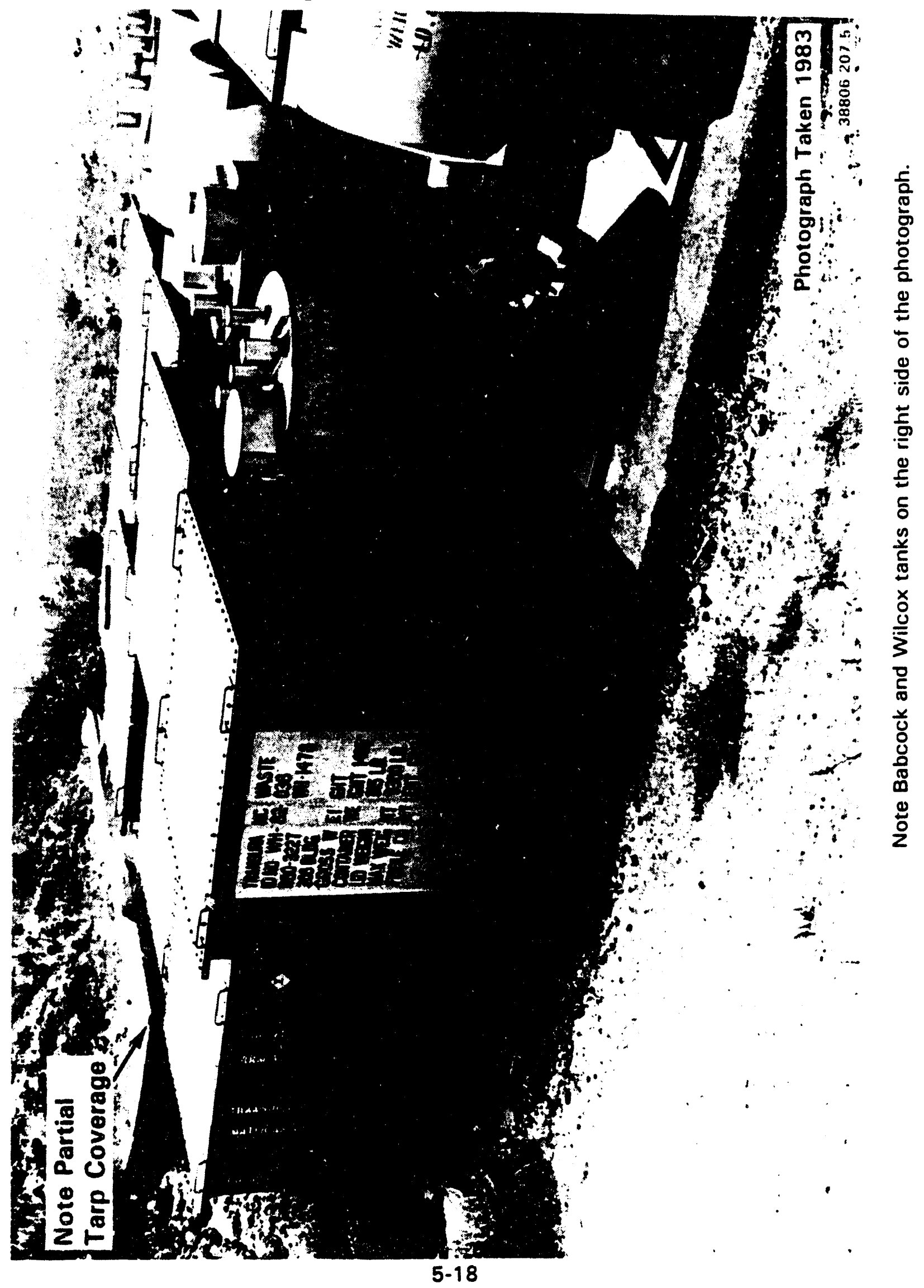


Figure 5-11. Grams of Transuranic Shipped to the Hanford Site by Babcock and Wilcox by Year.

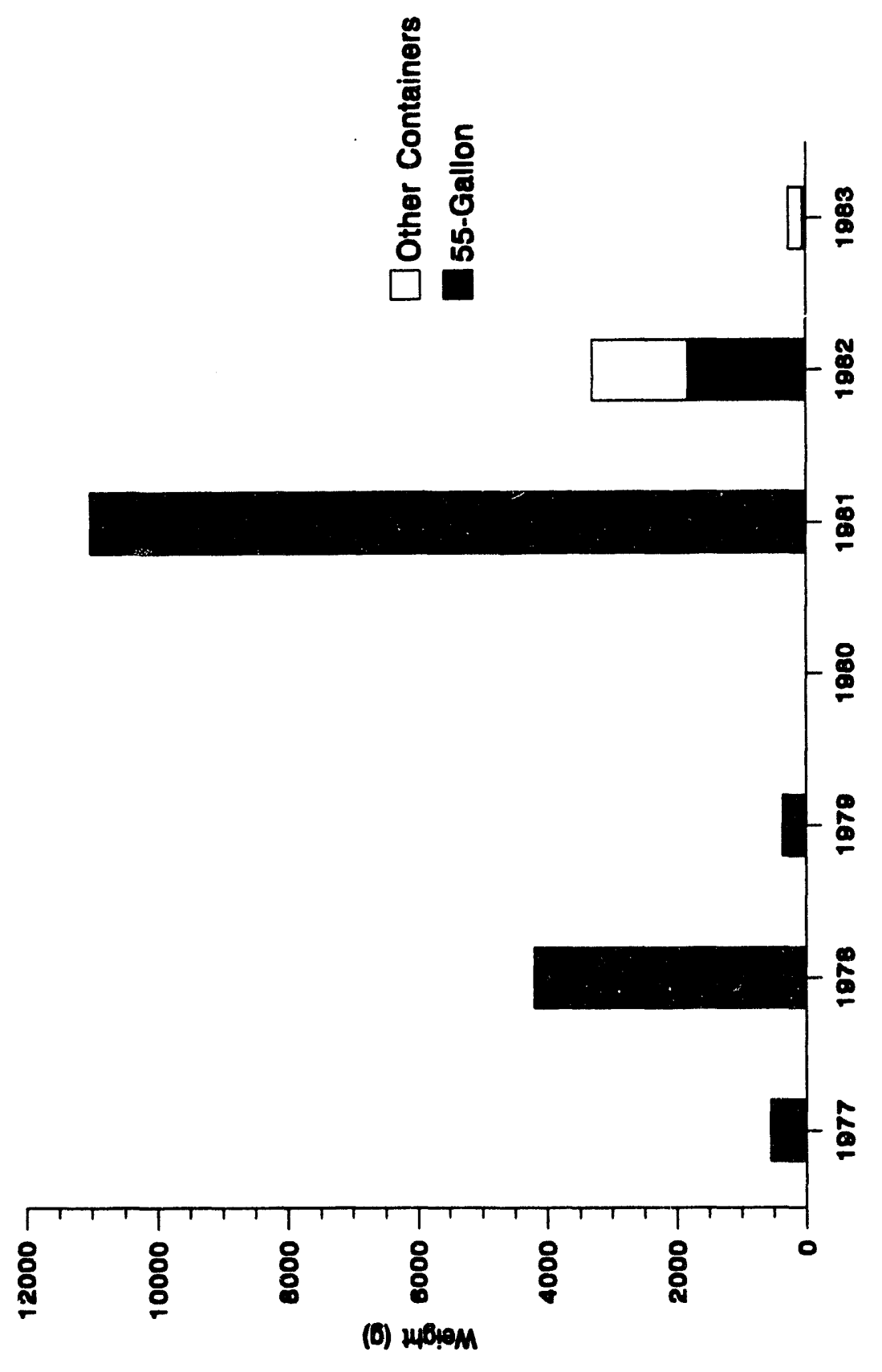


Table 5-1. Transuranic Waste Generated at Babcock and Wilcox by Container Type and Year. (2 sheets)

\begin{tabular}{|c|c|c|c|c|c|c|c|}
\hline Container type & Cuntainer size & $\begin{array}{l}\text { Number of } \\
\text { containers }\end{array}$ & Porcont of & Woltht & $\begin{array}{l}\text { Perosm } \\
\text { whipht } \\
\text { tost }\end{array}$ & $\begin{array}{l}\text { volume } \\
\left(m^{3}\right)\end{array}$ & $\begin{array}{c}\text { Percent } \\
\text { Volume } \\
\text { (\%) }\end{array}$ \\
\hline \multicolumn{8}{|c|}{1877} \\
\hline $\begin{array}{l}\text { Metal drums, berrels, or } \\
\text { kegs }\end{array}$ & -55-gal & 8 & 100 & 612 & 100 & 1.8 & 100 \\
\hline Total & & $\theta$ & & 612 & & 1.8 & 100 \\
\hline \multicolumn{8}{|c|}{1878} \\
\hline $\begin{array}{l}\text { Metel drums, berrels, or } \\
\text { kegs }\end{array}$ & -E5-gal & 168 & 100 & 13,388 & 100 & 32.2 & 100 \\
\hline Total & & 168 & & 13,388 & 100 & 32.2 & 100 \\
\hline \multicolumn{8}{|c|}{1979} \\
\hline $\begin{array}{l}\text { Motal drums, barrols, or } \\
\text { kegs }\end{array}$ & '56-gal & 127 & 100 & 6,791 & 100 & 26.2 & 100 \\
\hline Total & & 127 & & 5,791 & & 26.2 & \\
\hline \multicolumn{8}{|c|}{1080} \\
\hline \multicolumn{8}{|c|}{1881} \\
\hline \multirow{2}{*}{$\begin{array}{l}\text { Metal drums, barrels, } \\
\text { or kegs }\end{array}$} & "55-gal & 1 & 0.1 & 86 & 0.2 & .2 & 0.1 \\
\hline & 55-gal & 772 & 89.9 & 52,675 & 89.8 & 163.4 & 98.9 \\
\hline Totel & & 773 & & 52,680 & & 163.6 & \\
\hline \multicolumn{8}{|c|}{1082} \\
\hline \multirow{5}{*}{$\begin{array}{l}\text { Motal boxes, certons, } \\
\text { and cases }\end{array}$} & 4 by 5 by $6 \mathrm{ft}$ & 1 & 0.4 & 3,176 & 3.8 & 3.4 & 2.0 \\
\hline & 5 by 5 by $7 \mathrm{ft}$ & 7 & 2.9 & 20,400 & 24.4 & 34.3 & 20.2 \\
\hline & 5 by 5 by $\theta \mathrm{ft}$ & 1 & 0.4 & 2,737 & 3.3 & 6.2 & 3.6 \\
\hline & $\begin{array}{l}5.4 \text { by } 5.6 \text { by } \\
6.8 \mathrm{ft}\end{array}$ & 11 & 4.5 & 28,463 & 36.3 & 64.0 & 37.6 \\
\hline & 6 by 6 by $7 \mathrm{ft}$ & 2 & 0.8 & 6,360 & 7.6 & 12.8 & 7.6 \\
\hline $\begin{array}{l}\text { Motal drums, berrels, } \\
\text { or kegs }\end{array}$ & 65-gal & 223 & 81.4 & 18,862 & 23.8 & 47.3 & 27.8 \\
\hline Portable tanks & 4 by $4 \mathrm{ft}$ & 1 & 0.4 & 1,533 & 1.8 & 2.0 & 1.2 \\
\hline Toral & & 246 & & 83,510 & & 170.1 & \\
\hline
\end{tabular}


Table 5-1. Transuranic Waste Generated at Babcock and Wilcox by Container Type and Year. (2 sheets)

\begin{tabular}{|c|c|c|c|c|c|c|c|}
\hline Container type & Container size & $\begin{array}{l}\text { Number of } \\
\text { conteiners }\end{array}$ & $\begin{array}{c}\text { Percent of } \\
\text { total }\end{array}$ & $\begin{array}{l}\text { Wotont } \\
\text { (kol) }\end{array}$ & $\begin{array}{l}\text { poropht } \\
\text { wolpht } \\
\text { (s)i }\end{array}$ & $\begin{array}{l}\text { Volume } \\
\left(\mathrm{m}^{3}\right)\end{array}$ & $\begin{array}{l}\text { Percent } \\
\text { Volums } \\
\text { (\%) }\end{array}$ \\
\hline \multicolumn{8}{|c|}{1883} \\
\hline $\begin{array}{l}\text { Metal boxes, cartons, } \\
\text { and cases }\end{array}$ & $\begin{array}{l}5.4 \text { by } 5.6 \text { by } \\
6.8 \mathrm{ft}\end{array}$ & 3 & 1.8 & 8,682 & 42.1 & 17.6 & 36.6 \\
\hline $\begin{array}{l}\text { Metel drums, berrels, } \\
\text { or kegs }\end{array}$ & 65-gal & 161 & 88.1 & 11,939 & 67.9 & 32.0 & 64.5 \\
\hline Total & & 154 & & 20,631 & & 48.6 & \\
\hline
\end{tabular}

Waste attributed to another building in SWITS database.

'These containers hold mixed waste. 
Table 5-2. Babcock and Wilcox Waste Summary Data for Fifty-Five-Gallon Drums.

\begin{tabular}{|c|c|c|c|c|c|c|c|}
\hline 55 -gallon drums & 1977 & 1978 & 1979 & 1980 & 1981 & 1982 & 1983 \\
\hline \multicolumn{8}{|c|}{ Distribution } \\
\hline TRU count & 9 & 168 & 127 & & 773 & 223 & 151 \\
\hline TRU wt (kg) & 612 & 3,388 & 5,791 & & 52,660 & 19,852 & 11,939 \\
\hline TRU vol $\left(\mathrm{m}^{3}\right)$ & 1.9 & 32.2 & 26.2 & & 163.6 & 47.3 & 32.0 \\
\hline TRU MW count & 0 & 0 & 0 & & 1 & 0 & 0 \\
\hline Non-TRU count & 0 & 0 & 0 & & 0 & 0 & 0 \\
\hline Non-TRU wt (kg) & 0 & 0 & 0 & & 0 & 0 & 0 \\
\hline Non-TRU vol $\left(\mathrm{m}^{3}\right)$ & 0 & 0 & 0 & & 0 & 0 & 0 \\
\hline Non-TRU MW count & 0 & 0 & 0 & & 0 & 0 & 0 \\
\hline \multicolumn{8}{|c|}{ Percentage } \\
\hline$\%$ TRU by count & 100 & 100 & 100 & & 100 & 100 & 100 \\
\hline$\%$ non-TRU by count & 0 & 0 & 0 & & 0 & 0 & 0 \\
\hline Wt\% TRU & 100 & 100 & 100 & & 100 & 100 & 100 \\
\hline Wt\% non-TRU & 0 & 0 & 0 & & 0 & 0 & 0 \\
\hline Vol\% TRU & 100 & 100 & 100 & & 100 & 100 & 100 \\
\hline Vol\% non-TRU & 0 & 0 & 0 & & 0 & 0 & 0 \\
\hline $\begin{array}{l}\% \text { of TRU drums that } \\
\text { are TRU MW by count }\end{array}$ & 0 & 0 & 0 & & 0.1 & 0 & 0 \\
\hline $\begin{array}{l}\% \text { of non-TRU drums } \\
\text { that are MW by count }\end{array}$ & N/A & N/A & N/A & & N/A & N/A & N/A \\
\hline
\end{tabular}

$\mathrm{MW}=$ mixed waste.

TRU = transuranic. 
Table 5-3. Babcock and Wilcox Waste Summary Data for Containers Other Than 55-Gallon Drums.

\begin{tabular}{|c|c|c|c|c|c|c|c|}
\hline Other containers & 1977 & 1978 & 1979 & 1980 & 1981 & 1982 & 1983 \\
\hline \multicolumn{8}{|c|}{ Distribution } \\
\hline TRU count & & & & & 0 & 23 & 3 \\
\hline TRU wt (kg) & & & & & 0 & 63,659 & 8,692 \\
\hline TRU vol $\left(\mathrm{m}^{3}\right)$ & & & & & 0 & 122.8 & 17.6 \\
\hline TRU MW count & & & & & 0 & 0 & 0 \\
\hline Non-TRU count & & & & & 0 & 0 & 0 \\
\hline Non-TRU wt (kg) & & & & & 0 & 0 & 0 \\
\hline Non-TRU vol $\left(\mathrm{m}^{3}\right)$ & & & & & 0 & 0 & 0 \\
\hline Non-TRU MW count & & & & & 0 & 0 & 0 \\
\hline \multicolumn{8}{|c|}{ Percentage } \\
\hline$\%$ TRU by count & & & & & N/A & 100 & 100 \\
\hline$\%$ non-TRU by count & & & & & N/A & 0 & 0 \\
\hline Wt\% TRU & & & & & N/A & 100 & 100 \\
\hline Wt\% non-TRU & & & & & N/A & 0 & 0 \\
\hline Vol\% TRU & & & & & N/A & 100 & 100 \\
\hline Vol\% non-TRU & & & & & N/A & 0 & 0 \\
\hline $\begin{array}{l}\% \text { of TRU drums that } \\
\text { are TRU MW by count }\end{array}$ & & & & & $N / A$ & 0 & 0 \\
\hline $\begin{array}{l}\% \text { of non-TRU drums } \\
\text { that are MW by count }\end{array}$ & & & & & N/A & N/A & N/A \\
\hline
\end{tabular}

MW $=$ Mixed waste.

TRU = Transuranic. 
Table 5-4. Babcock and Wilcox Transuranic Waste in Fifty-Five-Gallon Drums--Drum Count by Storage Location.

\begin{tabular}{|c|c|c|c|c|c|c|c|}
\hline & 1977 & 1978 & 1979 & 1980 & 1981 & 1982 & 1983 \\
\hline $218-W-4 C$ & & 168 & 127 & & 773 & 223 & 151 \\
\hline $218-W-4 B$ & 9 & & & & & & \\
\hline
\end{tabular}

Table 5-5. Babcock and Wilcox Transuranic Waste in Containers Other Than Fifty-Five-Gallon Drums-Container Count by Storage Location.

\begin{tabular}{|c|c|c|c|c|c|c|c|}
\hline & 1977 & 1978 & 1979 & 1980 & 1981 & 1982 & 1983 \\
\hline $218-W-4 C$ & & & & & 0 & 23 & 3 \\
\hline
\end{tabular}


Table 5-6. Distribution and Percentage of Transuranic Fifty-Five-Gallon Drum Physical Contents by Storage Location--218-W-4C.

\begin{tabular}{|c|c|c|c|c|c|c|c|}
\hline 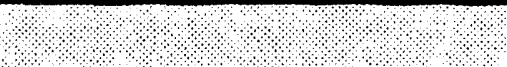 & 1977 & 1978 & 1979 & 1980 & 1981 & 1982 & 1983 \\
\hline \multicolumn{8}{|c|}{ Distribution } \\
\hline Cement & & & & & 190 & 162 & 87 \\
\hline Ceramics & & & & & & 52 & \\
\hline Cloth/rags/nylon & & & 42 & & & 15 & \\
\hline Filters & & & 84 & & 258 & 49 & 64 \\
\hline Glass & & & & & 304 & 62 & \\
\hline Metal/iron/galvanized/sheet & & & & & 304 & 166 & 87 \\
\hline Misc/unknown/other & 9 & 168 & 43 & & 66 & & \\
\hline Paper/cartboard & & & 42 & & 403 & 57 & 64 \\
\hline Plastic/polyurethane & & & 42 & & 403 & 57 & 64 \\
\hline Plexiglass & & & & & & 104 & 87 \\
\hline Rubber & & & & & 403 & 42 & 64 \\
\hline Wood/lumber/plywood & & & 42 & & 377 & 57 & 64 \\
\hline \multicolumn{8}{|c|}{ Percentage } \\
\hline Cement & & & & & 25 & 73 & 58 \\
\hline Ceramics & & & & & & 23 & \\
\hline Cloth/rags/nylon & & & 33 & & & 7 & \\
\hline Filters & & & 66 & & 33 & 22 & 42 \\
\hline Glass & & & & & 39 & 28 & \\
\hline Metal/iron/galvanized/sheet & & & & & 39 & 74 & 58 \\
\hline Misc/unknown/other & 100 & 100 & 34 & & 9 & & \\
\hline Paper/cardboard & & & 33 & & 52 & 26 & 42 \\
\hline Plastic/polyurethane & & & 33 & & 52 & 26 & 42 \\
\hline Plexiglass & & & & & & 47 & 58 \\
\hline Rubber & & & & & 52 & 19 & 42 \\
\hline Wood/lumber/plywood & & & 33 & & 49 & 26 & 42 \\
\hline
\end{tabular}


Table 5-7. Distribution and Percentage of Transuranic Containers Other Than Fifty-Five-Gallon Drum Physical Contents by Storage Location--218-W-4C.

\begin{tabular}{|c|c|c|c|c|c|c|c|}
\hline : & 1977 & 1978 & 1979 & 1980 & 1981 & 1982 & 1983 \\
\hline \multicolumn{8}{|c|}{ Distribution } \\
\hline Brick/firebrick & & & & & & 3 & \\
\hline Cement & & & & & & 7 & 1 \\
\hline Concrete & & & & & & 2 & \\
\hline Filters & & & & & & & 1 \\
\hline Glass & & & & & & 23 & 1 \\
\hline Metal/iron/galvanized/sheet & & & & & & 23 & 3 \\
\hline Stainless steel & & & & & & 2 & \\
\hline s. & s. & rconta & & & & ?. & \\
\hline Brick/firebrick & & & & & & 13 & \\
\hline Cement & & & & & & 30 & 33 \\
\hline Concrete & & & & & & 9 & \\
\hline Filters & & & & & & & 33 \\
\hline Glass & & & & & & 100 & 33 \\
\hline Metal/iron/galvanized/sheet & & & & & & 100 & 100 \\
\hline Stainless steel & & & & & & 9 & \\
\hline
\end{tabular}


Table 5-8. Babcock and Wilcox Transuranic Waste in Fifty-Five-Gallon Drums--Total Grams Transuranic by Storage Location.

\begin{tabular}{|c|c|c|c|c|c|c|c|}
\hline Location & 1977 & 1978 & 1979 & 1980 & 1981 & 1982 & 1983 \\
\hline $218-W-4 B$ & 574.0 & & & & & & \\
\hline $218-W-4 C$ & & $4,198.0$ & 369.0 & & 11.033 .8 & $1,818.9$ & 47.2 \\
\hline
\end{tabular}

Table 5-9. Babcock and Wilcox Transuranic Waste in Containers Other Than Fifty-Five-Gallon Drums--Total Grams Transuranic by Storage Location.

\begin{tabular}{|c|c|c|c|c|c|c|c|}
\hline Location & 1977 & 1978 & 1979 & 1980 & 1981 & 1982 & 1983 \\
\hline $218-W-4 C$ & & & & & & $1,478.2$ & 221.4 \\
\hline
\end{tabular}

Table 5-10. Fifty-Five-Gallon Drum Waste from Babcock and Wilcox Containing Greater than 175 Grams Transuranic.

\begin{tabular}{|c|c|c|c|c|c|c|}
\hline $\begin{array}{l}\text { Disposal! } \\
\text { date. }\end{array}$ & $\begin{array}{l}\text { Container } \\
\text { identification }\end{array}$ & $\begin{array}{l}\text { Storago } \\
\text { location }\end{array}$ & $\begin{array}{l}\text { Woight } \\
\text { (kg) }\end{array}$ & Tho & $\begin{array}{l}\text { Physical } \\
\text { contents }\end{array}$ & $\begin{array}{l}\text { Hazard } \\
\text { comp }\end{array}$ \\
\hline $04 / 26 / 77$ & $\begin{array}{l}\text { 234-5-ARCHO-77-407 } \\
\text { (BW: H-77-4-11) }\end{array}$ & 218-W-4B & 68 & 194 & Misc/unknown/other & \\
\hline $11 / 21 / 78$ & $\begin{array}{l}\text { 325-WHC-78-172 } \\
\text { (BW: WH-101-W) }\end{array}$ & $218-W-4 C$ & 68 & 179 & Misc/unknown/other & \\
\hline
\end{tabular}

Average weight.

TRU = transuranic waste. 
Table 5-11. Other Container Waste from Babcock and Wilcox Containing Greater than 175 Grams Transuranic.

\begin{tabular}{|c|l|c|c|c|c|c|c|}
\hline $\begin{array}{c}\text { Disposal } \\
\text { date }\end{array}$ & $\begin{array}{c}\text { Container } \\
\text { identification }\end{array}$ & $\begin{array}{c}\text { Storage } \\
\text { location }\end{array}$ & $\begin{array}{c}\text { Weight } \\
(\mathrm{kg})\end{array}$ & $\begin{array}{c}\text { TRU } \\
(\mathrm{g})\end{array}$ & $\begin{array}{c}\text { Physical contents } \\
\text { Contents }\end{array}$ & $\begin{array}{c}\text { Percent } \\
\text { Cazard } \\
\text { comp }\end{array}$ \\
\hline $09 / 17 / 82$ & $353618-2$ & $218-W-4 C$ & 2980 & 196 & $\begin{array}{c}\text { Metal } \\
\text { Glass }\end{array}$ & $\begin{array}{r}89.5 \\
10.3\end{array}$ & \\
& (BW: MK-1-67) & & & & $\begin{array}{c}\text { Cement } \\
0.2\end{array}$ & \\
\hline $09 / 17 / 82$ & $353619-2$ & $218-W-4 C$ & 2791 & 185 & Metal & 95.3 & \\
& & & & & Glass & 4.5 & \\
& (BW: MK-57) & & & & Cement & 0.3 & \\
\hline $02 / 07 / 83$ & $353617-1$ & $218-W-4 C$ & 2619 & 191 & Metal & 87.5 & \\
& & & & & Glass & 11.5 & \\
& (BW: MK-1-3) & & & & Cement & 1.0 & \\
\hline
\end{tabular}

TRU $=$ Transuranic.

Table 5-12. Summary of Information from Solid Waste Storage Disposal Records for TRU Wastes with Hazardous Contents from Babcock and Wilcox.

\begin{tabular}{|c|c|c|c|c|c|c|}
\hline $\begin{array}{c}\text { Date } \\
\text { Accepted }\end{array}$ & $\begin{array}{c}\text { Pin Number } \\
\text { necord Number }\end{array}$ & $\begin{array}{c}\text { Hazardous } \\
\text { Constituents }\end{array}$ & $\begin{array}{l}\text { Waste } \\
\text { Codes }\end{array}$ & $\begin{array}{c}\text { Weight } \\
(\mathrm{kg})\end{array}$ & $\begin{array}{c}\text { Volume } \\
(\%)\end{array}$ \\
\hline $11 / 12 / 81$ & $\begin{array}{c}3536-10-A \\
(B \& W \text { S-713) }\end{array}$ & BABCX-APA-81-7 & Beryllium & & & \\
\hline
\end{tabular}


WHC-EP-0719

\subsection{REFERENCES}

AEC, 1970, Immediate Action Directive, IAD-0511-21, U.S. Atomic Energy Commission, Washington, D.C.

AEC, 1973, Atomic Energy Commission Manual, Chapter 0511, "Radioactive Waste Management," U.S. Atomic Energy Commission, Washington, D.C.

Anderson, B. C., J. D. Anderson, J. A. Demiter, D. R. Duncan, L. A. Fort, D. C. McCann, and S. J. Stone, 1991, Contact-Handled Transuranic Waste Characterization Based on Existing Records, WHC-EP-0225, Revision 1, Westinghouse Hanford Company. Richland, Washington.

Babcock and Wilcox, 1983, Technical Data Summary Report on Decontamination and Removal of Equipment in the Parks Township Site Plutonium Facility - May 1983. Babcock and Wilcox Company, Apollo, Pennsylvania.

Bradley, J. G., and D. E. Clark, 1978, Waste Generated During Fabrication of Mixed Oxide Nuclear Fuels, HEDL-TME-78-71, Hanford Engineering Development Laboratory, Richland, Washington.

DOE, 1982, Management of Transuranic Material, DOE Order 5820.1, U.S. Department of Energy, Washington, D.C.

Duncan, D. R., 1991, Solid Waste Program Plan (Appendix A), WHC-EP-0363, Rev. 1, Westinghouse + nford Company, Richland, Washington.

Duncan, D. R., D. A. Burbank, B. C. Anderson, and J. A. Demiter, 1992, Application of Service Examinations to Transuranic Waste Container Integrity at the Hanford Site, WHC-SA-1450-FP, Rev. 1, Westinghouse Hanford Company, Richland, Washington.

40 CFR 265, 1991, "Interim Status Standards for Owners and Operators of Hazardous Waste Treatment, Storage, and Disposal Facilities," Code of Federal Regulations, as amended.

52 FR 1987, "Radioactive Waste: Byproducts Material Final Rule," Federal Register, Vol. 52 (84), pp 15937-15941.

Reddinger, R. W., 1992, Unstable and Reactive Chemicals in Transuranic Retrievable Waste at the Hanford Site - A Review of Available Data, WHC-EP-0603. Westinghouse Hanford Company, Richland, Washington.

Resource Conservation and Recovery Act of 1976, 42 USC 6901 et seq.

Willis, N. P., and G. C. Triner, 1991, Hanford Site Radioactive Solid Waste Acceptance Criteria, WHC-EP-0063-3, Westinghouse ilanford Company, Richland, Washington. 
WHC-EP-0719

This page intentionally left blank. 
WHC-EP-0719

\section{APPENDIX A}

DATA ON BABCOCK AND WILCOX WASTE GENERATION FROM THE SOLID WASTE INFORMATION TRACKING SYSTEM 
WHC-EP-0719

This page intentionally left blank. 


\section{DATA ON BABCOCK AND WILCOX WASTE GENERATION FROM THE SOLID WASTE INFORMATION TRACKING SYSTEM}

The information found in this appendix is from the Solid Waste Information and Tracking System (SWITS) database. This database incorporates the older R-SWIMS database and is used to track information on radioactive and other wastes storeci or disposed at the Hanford Site.

Each SWITS data run in this appendix is preceded by the query used to generate the data. A brief explanation of the run and any additional information needed to understand the data presented also is included.

The bulk of the data provided is limited to information about TRU waste generated at Babcock and Wilcox; however, some general information on the non-TRU waste is included for completeness. The term non-TRU is used, instead of LLW, because a small percentage of the waste has been designated only as not TRU. It is believed that most, if not all, of the non-TRU waste is LLW.

The data runs in this appendix are further segregated by waste container type. Since initial retrieval efforts and WRAP 1 will focus on 55-gal drums, these container types are considered separately.

Some general information about SWITS database and the codes used follows. Please note the disclaimer found on the next page. 


\section{WHC-EP-0719}

DON'T SAY IT -- Write It!

Date:

To:<smiles>CC(C)OC1CCCC1</smiles>

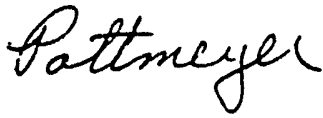

From:

Solid Waste Engineering Data Management Group N3-11 6-4394/6-4020

Re: SWITS DATA REQUEST

Attached for your information and use is the data which you requested. This data represents best available information regarding wastes currently in storage at the Hanford site. I trust the information will be suitable to your needs.

Requests for information from the solid Waste Information and Tracking system (SWITS) are normally relatively limited in scope, requesting specific data fields or summary data. The responses to these requests undergo review during data collection, summary and response preparation.

The response to this request represents a simple reproduction of the SWITS Database. Transmittal of this information is made with the following disclaimers :

1) The information contained in this transmittal is raw data, and reprecents information provided to Solid Waste Engineering (SWE) on burial records or other documents. This data has not been validated.

2) The information contained in this transmittal is subject to change without notice. Continual update of SWITS information and improvement of the software system make it impossible to ensure consistency of this data with the database after transmittal.

3) This information is current as of $12 / 11 / 92$.

If I can be of further assistance to you, do not hesitate to call me. 
WHC-EP-0719

APPENDIX A.1

CONTAINER NUMBER AND WEIGHT OF TRANSURANIC WASTE IN FIFTY-FIVE-GALLON DRUMS BY WASTE TYPE

A.1-1 
WHC-EP-0719

This page intentionally left blank.

A.1-2 
CONTAINER NUMBER AND WEIGHT OF TRANSURANIC WASTE IN FIFTY-FIVE-GALLON DRUMS BY WASTE TYPE

This data run gives an overall look at the waste types, container numbers, and total weight (in kilograms) of the radioactive wastes generated yearly at Babcock and Wilcox. These data are for wastes stored in 55-gal drums only. The introduction to Appendix A contains a table of primary and secondary waste codes and their meanings.

From 1970 until 1978 individual container weights were not required for TRU drums. During the data reentry program in the mid-1980's, standard weights were assigned for all container types; 55-gal drums were given a standard weight of $68 \mathrm{~kg}$. This is why the average weight/drum for TRU is so consistent during this period. 


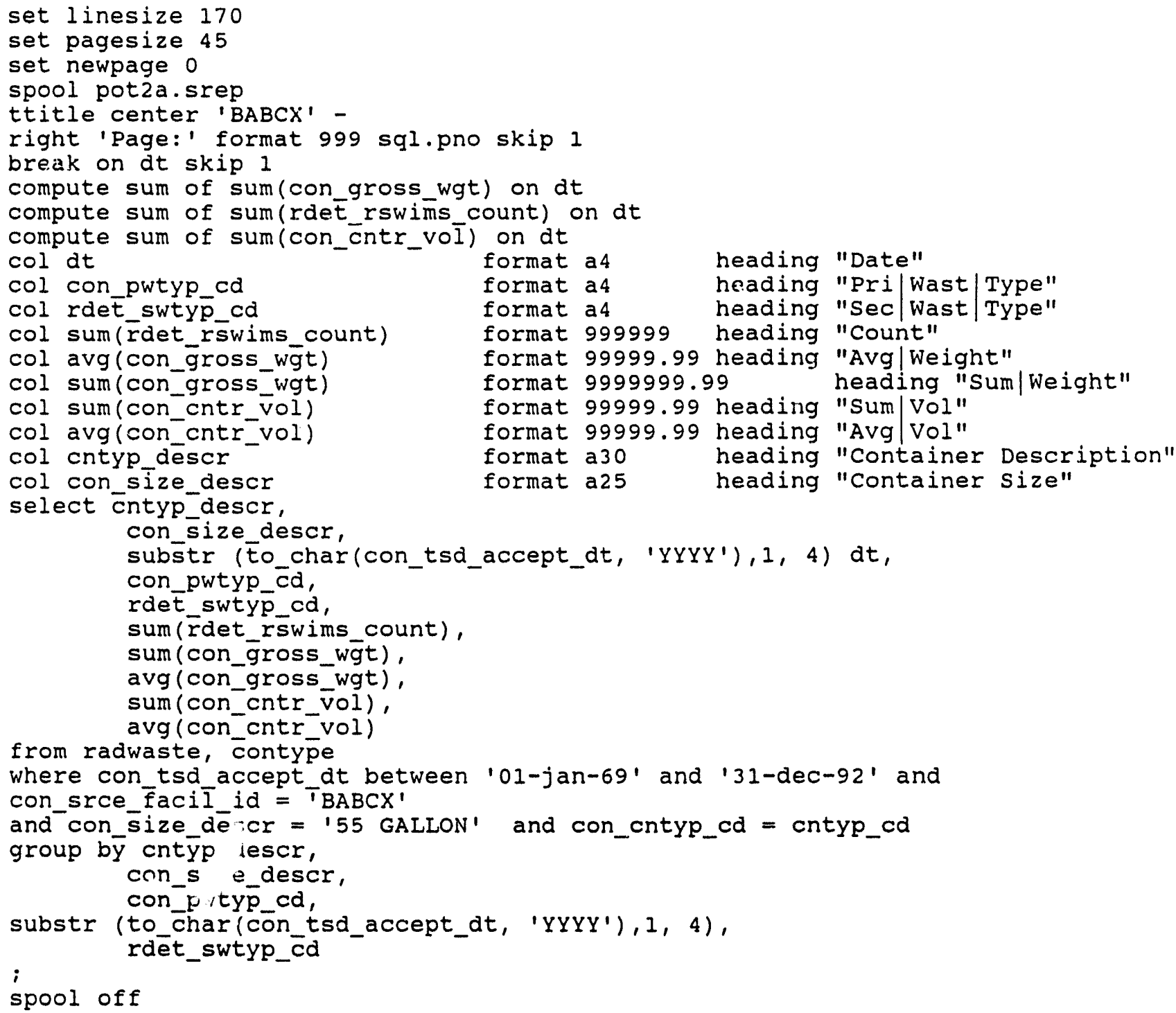




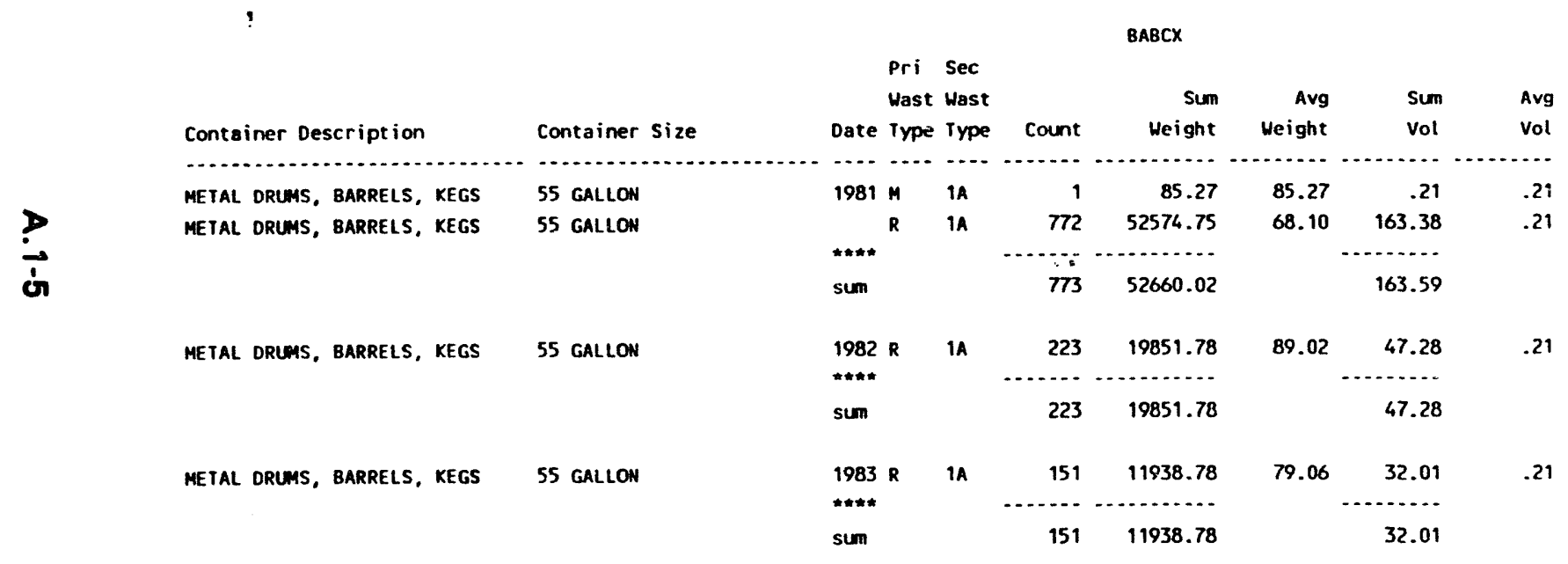


WHC-EP-0719

This page intentionally left blank.

A. 1-6 
WHC-EP-0719

\section{APPENDIX A.2}

\section{BABCOCK AND WILCOX TRANSURANIC WASTE CONTANERS} SORTED BY CONTAINER DESCRIPTION, SIZE, YEAR, AND PRIMARY WASTE TYPE 
WHC-EP-0719

This page intentionally left blank.

A. 2-2 


\section{BABCOCK AND WILCOX TRANSURANIC WASTE CONTANERS SORTED BY CONTAINER DESCRIPTION, SIZE, YEAR, AND PRIMARY WASTE TYPE}

This subappendix provides information on Babcock and Wilcox TRU waste containers, weight, volume, and primary waste type stored at various TRU waste storage facilities on the Hanford Site. The data provides the TRU waste generation from the Babcock and Wilcox facility by year. 


\section{WHC-EP-0719}

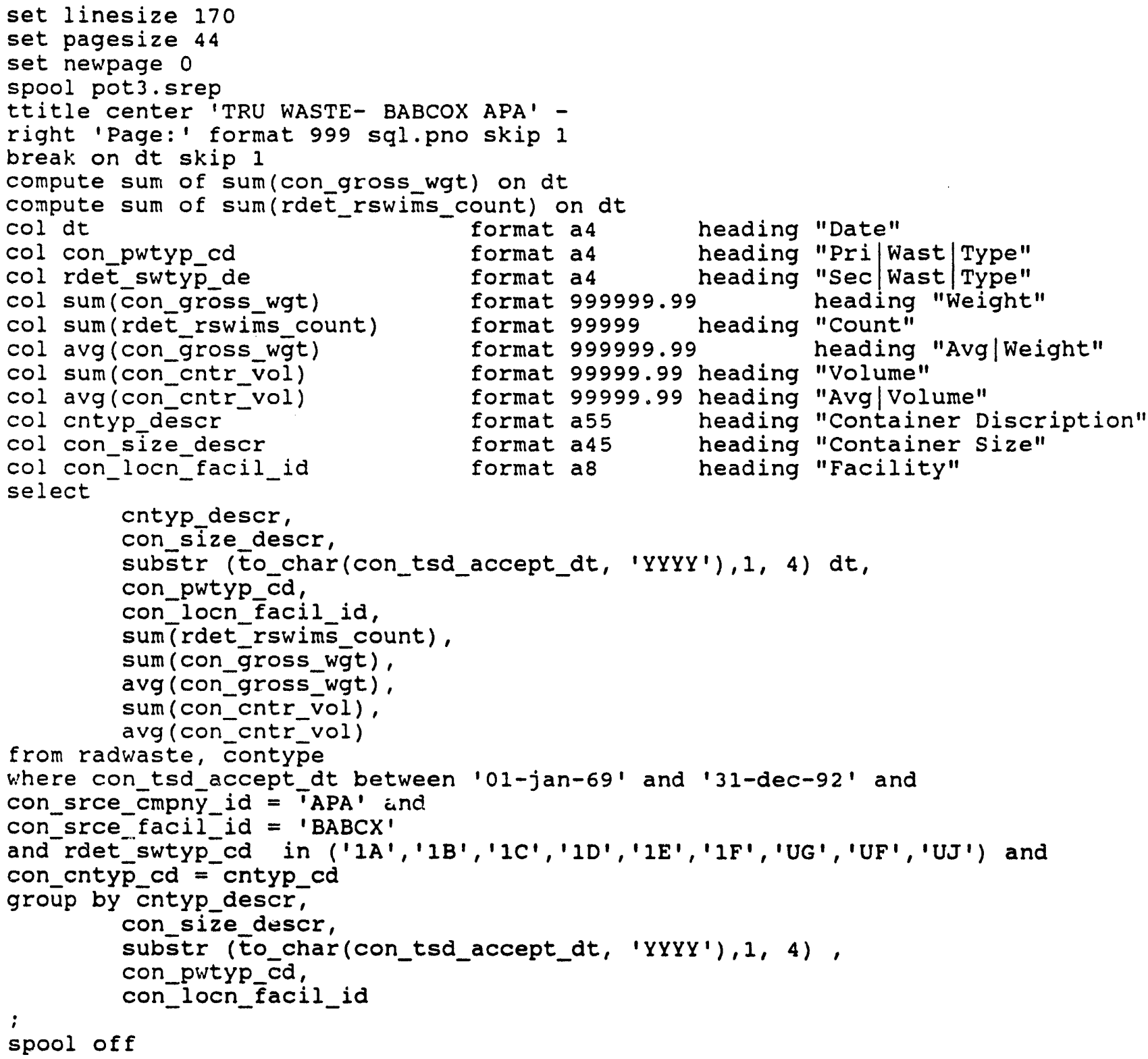


IRU WASTE - BABCOX APA

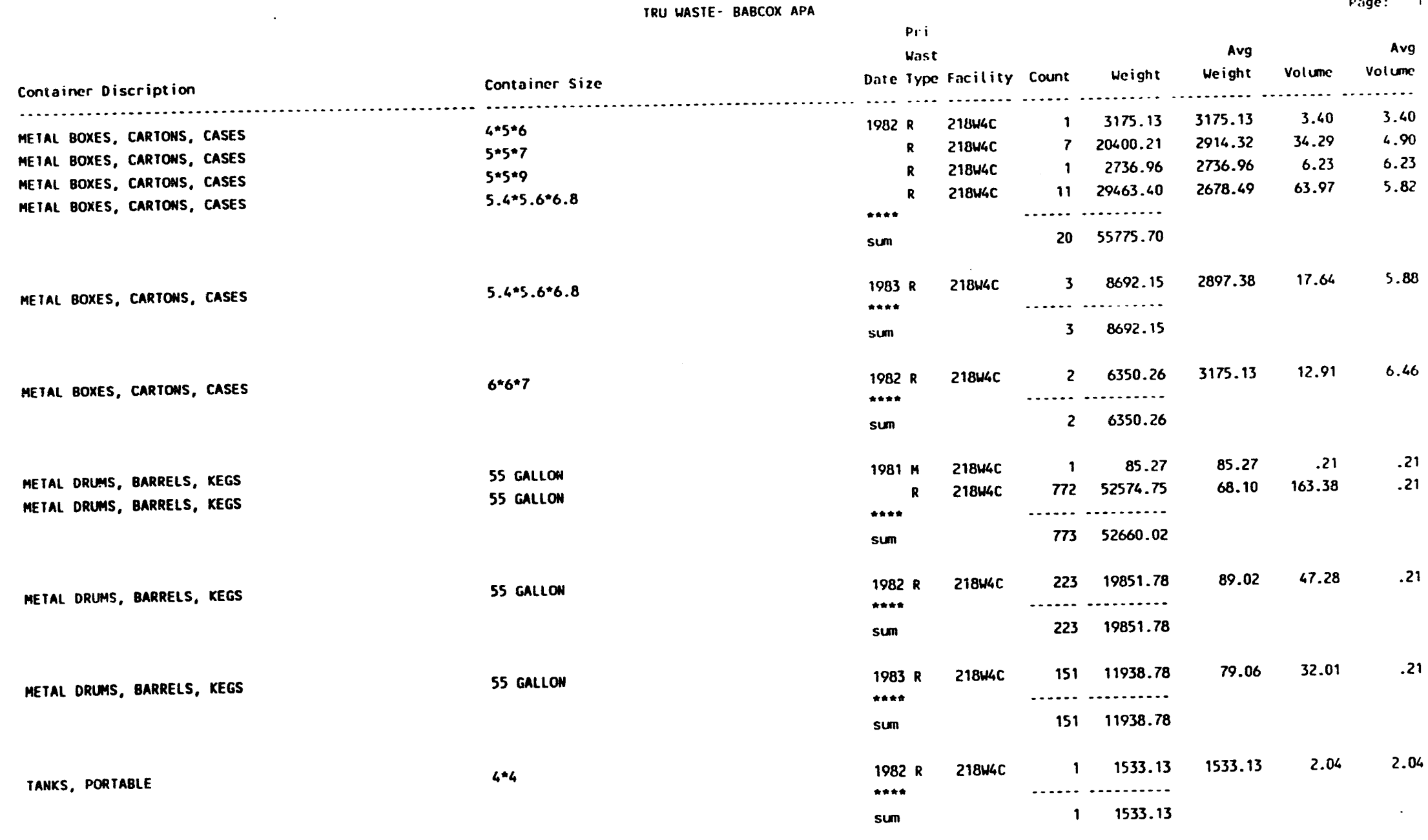


WHC-EP-0719

This page intentionally left blank.

\section{A.2-6}


WHC-EP-0719

APPENDIX A.3

RADIOLOGICAL DATA FOR TRANSURANIC WASTE CONTAINERS

SORTED BY DATE, PRIMARY WASTE TYPE, AND STORAGE FACILITY 
WHC-EP-0719

This page intentionally left blank.

\section{A.3-2}




\section{RADIOLOGICAL DATA FOR TRANSURANIC WASTE CONTAINERS \\ SORTED BY DATE, PRIMARY WASTE TYPE, AND STORAGE FACILITY}

This subappendix summarizes the radiological data for all TRU waste containers generated at Babcock and Wilcox. Specifically, this computer run provides the total grams of TRU elements in a given container type in a given year. Additionally, the average gram loading for a given container type in a given year has been calculated.

In 1991 and 1992 the number of curies ( $\mathrm{Ci}$ ) of alpha radiation was included on the SWBRs. Since the Babcock and Wilcox waste generation data is all from 1970 to 1988 . these columns contain blank entries. The "Max Dose" column contains the highest value recorded for a given container in a given year, in millirems per hour.

Additional information about the isotopes present in Babcock and Wilcox waste containers can be found in subappendices A.9 and A.10. 


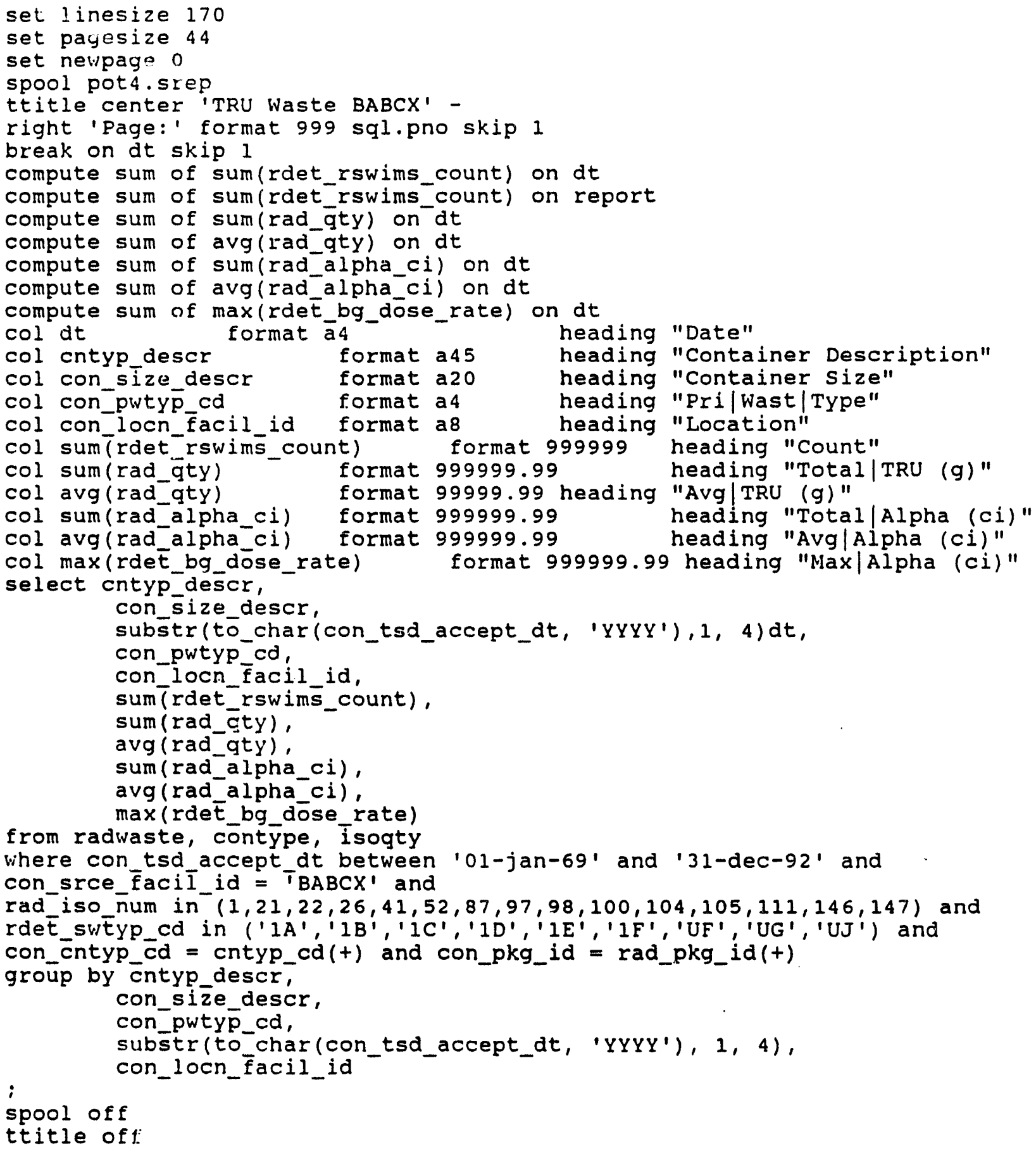




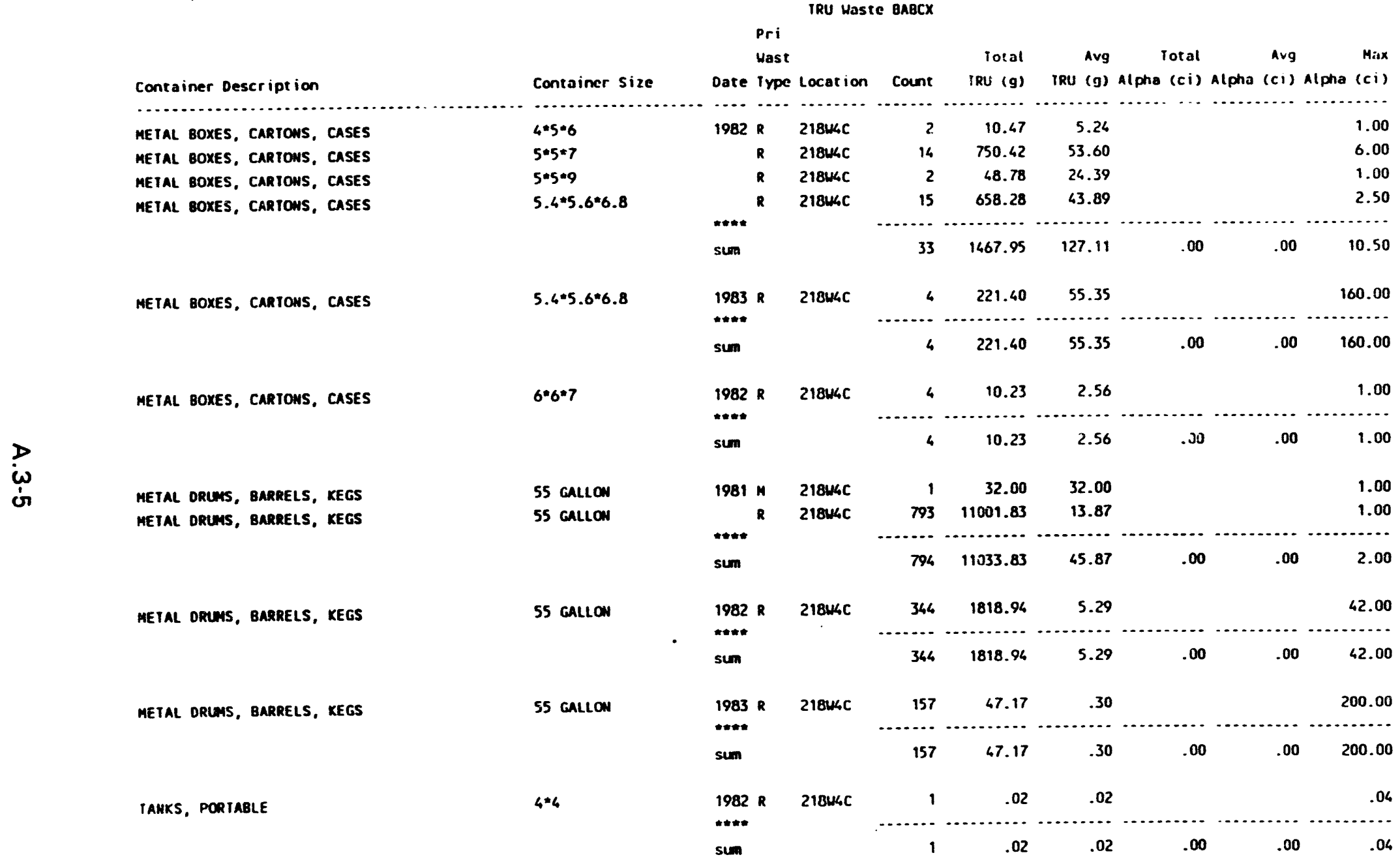

11 rows selected. 
WHC-EP-0719

This page intentionally left blank.

A.3-6 
WHC-EP-0719

APPENDIX A.4

PHYSICAL CONTENTS DESCRIPTION FOR BABCOCK AND WILCOX FIFTY-FIVE-GALLON DRUMS CONTAINING TRANSURANIC WASTE SORTED BY DATE, PRIMARY

WASTE TYPE, AND STORAGE FACILITY 
WHC-EP-0719

This page intentionally left blank.

A.4-2 
PHYSICAL CONTENTS DESCRIPTION FOR BABCOCK AND WILCOX FIFTY-FIVE-GALLON DRUMS CONTAINING TRANSURANIC WASTE SORTED BY DATE, PRIMARY WASTE TYPE, AND STORAGE FACILITY

This subappendix describes the physical contents of the 55-gal drums of TRU waste generated by Babcock and Wilcox. Because physical contents were not required on the burial records before 1978, a great many of the early records list the contents of the drum as "Miscellaneous."

The printout for this computer run sorts the contents data by storage facility, date, and primary waste type. The introduction to Appendix $A$ contains a table of waste codes and their meanings. 


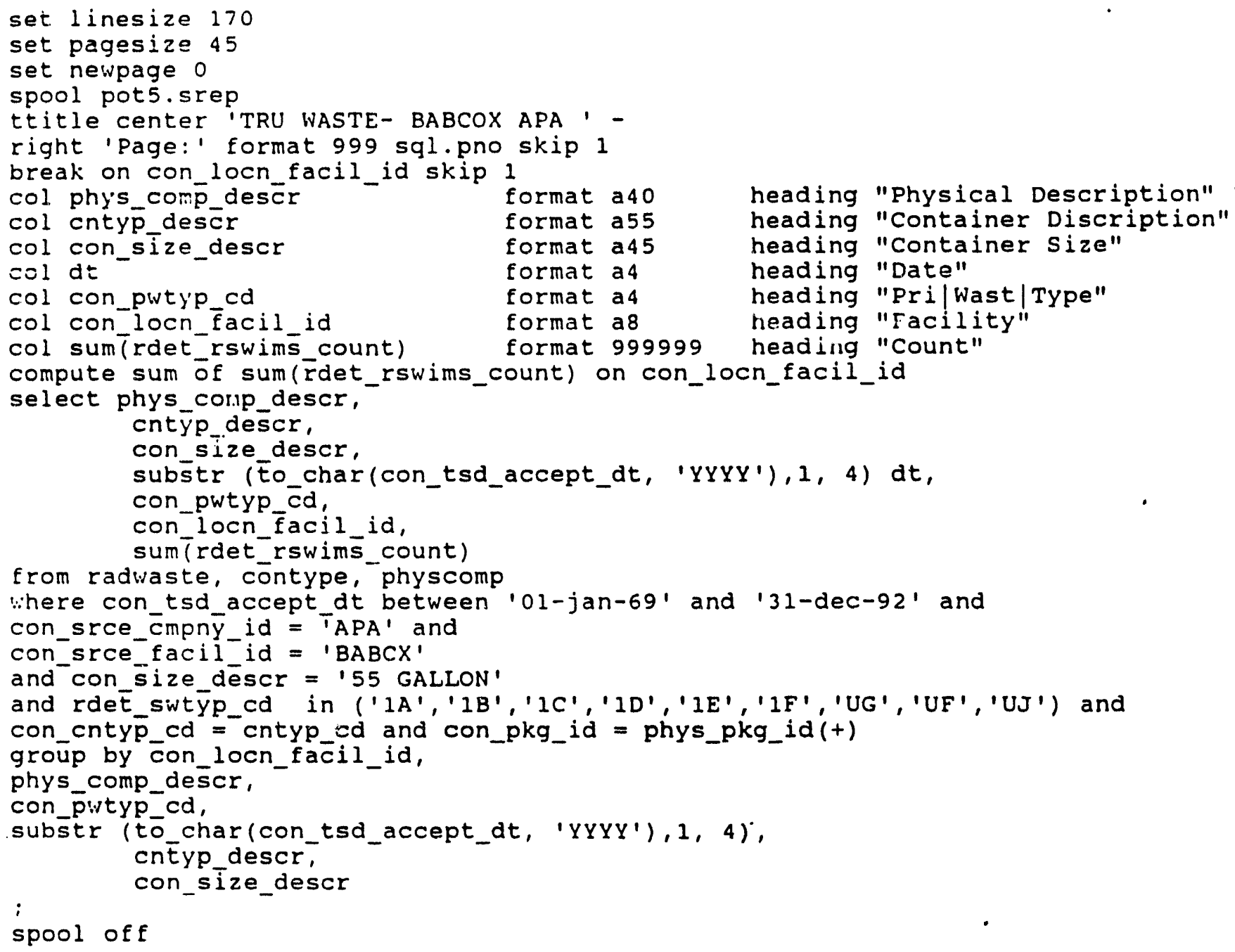




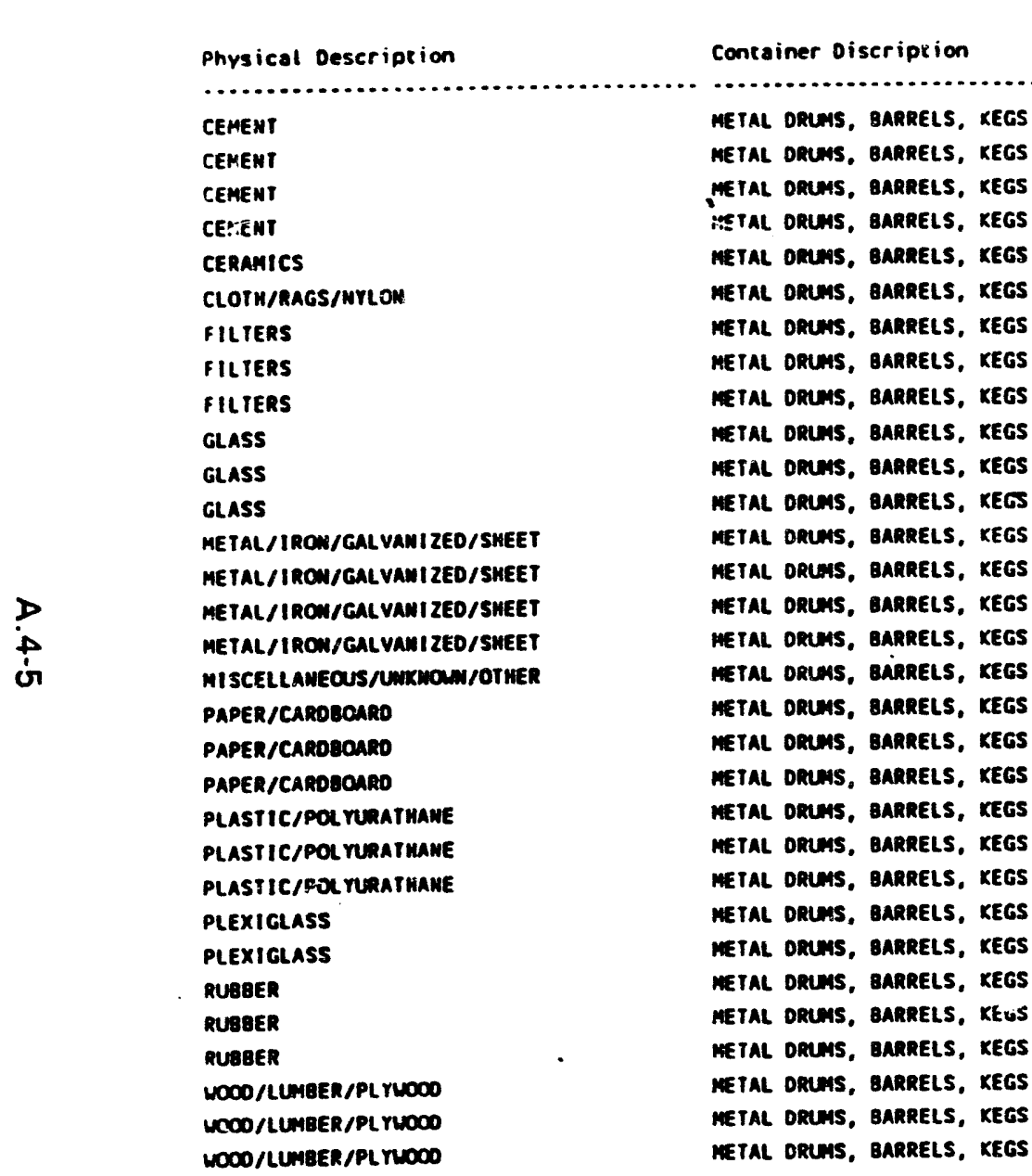

Coneainer size

Mast Dace iype facility cant Date irpe faciliter cant

s5 callon

55 Gallon

55 galion

55 Gallon

55 GALLOM

55 Gallon

55 gallon

SS GALLOH

55 GaLLO

55 Gallom

35 Gallon

55 GALLON

S5 Gallon

55 GaLLO

55 GAllON

55 GALLOON

55 Gallom

is Gallow

5:5 Gallon

55 gallow

55 callo

55 gaclon

55 GRLLOM

55 gallon

55 galloon

55 Gallon

55 Gallo

55 gallon

55 Gallon

55 GALLON

55 GALLON

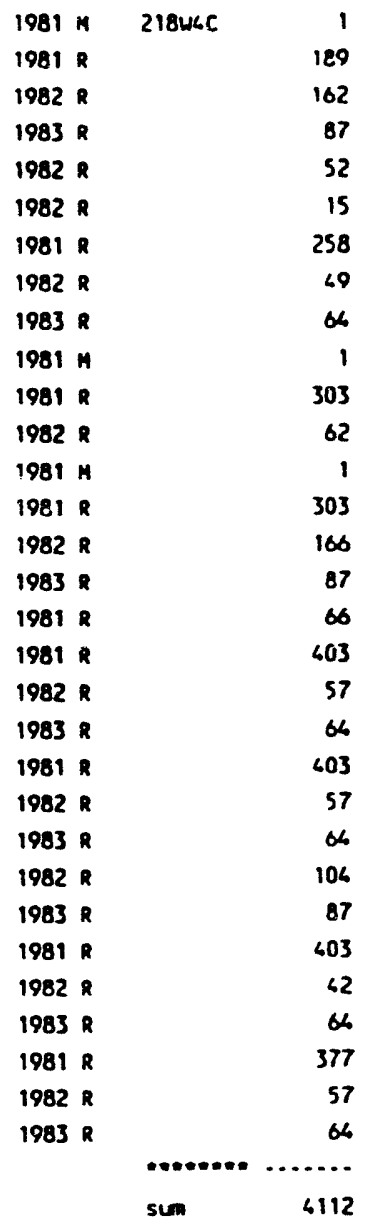


WHC-EP-0719

This page intentionally left blank.

A.4-6 
WHC-EP-0719

APPENDIX A.5

PHYSICAL CONTENTS DESCRIPTION FOR BABCOCK AND WILCOX TRANSURANIC WASTE CONTAINERS OTHER THAN FIFTY-FIVE-GALLON DRUMS SORTED BY DATE, PRIMARY WASTE TYPE, AND STORAGE FACILITY 
WHC-EP-0719

This page intentionally left blank.

A.5-2 
PHYSICAL CONTENTS DESCRIPTION FOR BABCOCK AND WILCOX TRANSURANIC

WASTE CONTAINERS OTHER THAN FIFTY-FIVE-GALLON DRUMS SORTED

BY DATE, PRIMARY WASTE TYPE, AND STORAGE FACILITY

This subappendix describes the physical contents of the TRU waste containers other than 55-gal drums generated at Babcock and Wilcox. Because physical contents were not required on the burial records before 1978, a great many of the early records list the contents of the drum as "Miscellaneous."

The printout for this computer run sorts the contents data by storage facility, date, and primary waste type. The introduction to Appendix A contains a table of waste codes and their meanings. 


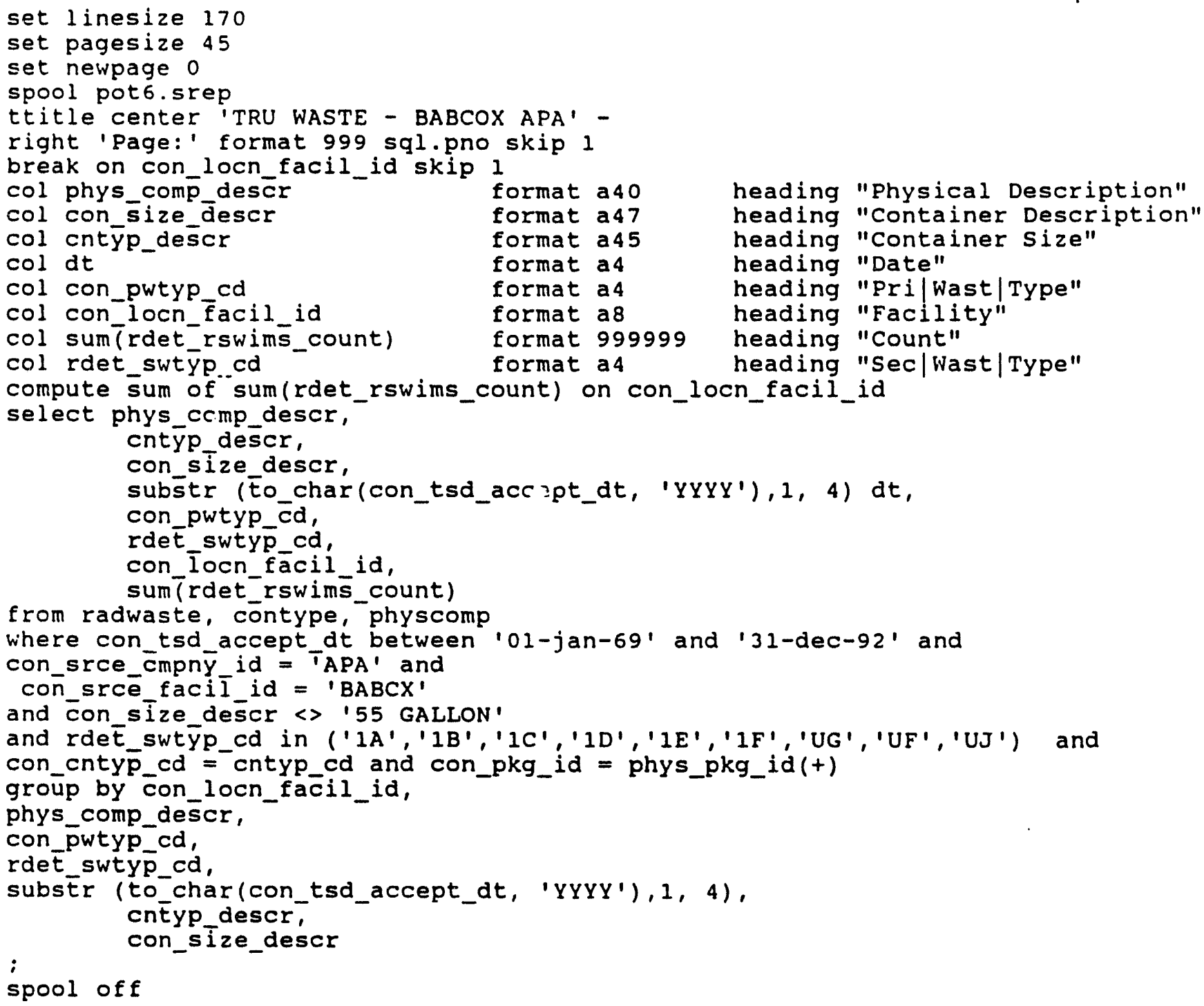




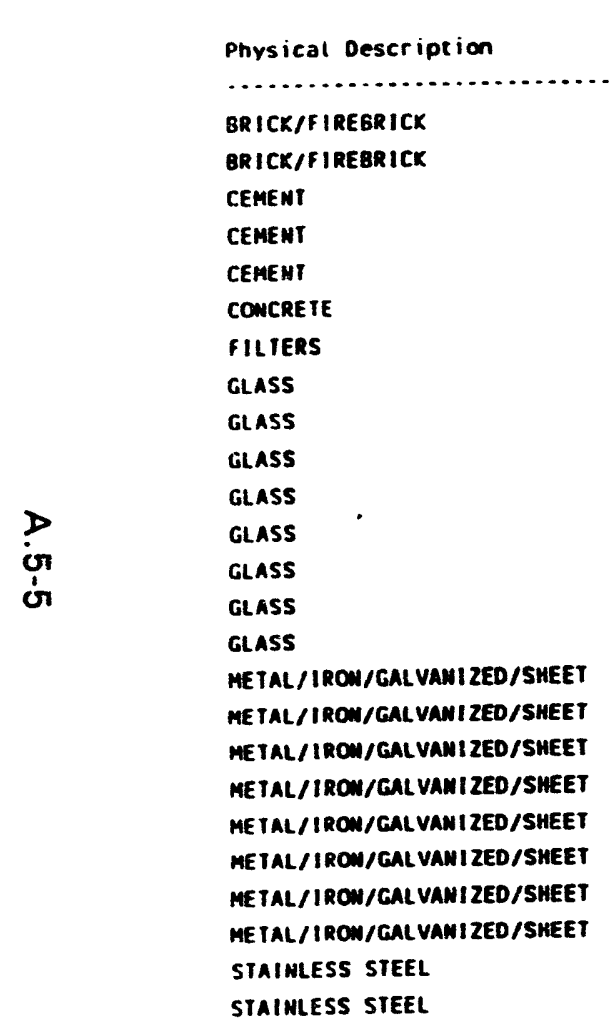

25 rows selected.
Container size

Metal boXes, cartons, cases

metal boXEs, cartous, cases

METAL BOXES, CARTOWS, CASES

METAL BOXES, CARTONS, CASES

METAL BOXEs, Cartows, Cases

METAL BOXES, CARTOWS, CASES

METAL BOXES, CARTONS, CASES

Metal boXes, cartons, cases

METAL BOXEs, cartons, cases

METAL BOXES, CARTOWS, CASES

METAL BOXES, CARTOWS, CASES

METAL 8OXES, CARTONS, CASES

tanks, portable

METAL BOXES, CARTOUS, CASES

METAL BOXEs, Cartons, Cases

METAL BOXES, CARTONS, CASES

METAL BOXES, CARTOWS, CASES

METAL BOXES, CARTOWS, CASES

METAL BOXES, CARTONS, CASES

METAL BOXES, CARTOUS, CASES

iaMKS, PORTABLE

METAL BOXES, CARTONS, CASES

METAL BOXES, CARTONS, CASES

metal BoXEs, cartows, CaSEs

tAMKS, PORTABLE
Container Description

$5=5=9$

$5=5 * 7$

$5=5 * 7$

$5.4 * 5.6 * 6.8$

$5.4 * 5.6 * 6.8$

$5 * 5 * 7$

$5.4 * 5.6 * 6.8$

$4=5=6$

$5 * 5 * 7$

$5 \times 5 * 9$

$5.4 * 5.6=6.8$

$6=6 * 7$

$4 \pm 6$

$5.4 * 5.6 * 6.8$

$5 * 5 * 7$

$4=5 * 6$

5-5"7

$5 * 5 * 9$

$5.4 * 5.6 * 6.8$

$6 * 6 * 7$

$4 \times 4$

$5.6 * 5.6 * 6.8$

$5 * 5 * 7$

$5.4 * 5.6 * 6.8$

$4 * 4$

Pri See

Wast Wast

Date Iype irpe facility count

1982 R in 21844C

$1982 R$ id

1982 R 1082 R iA

$1982 R$

1982 R iA

1983 R IA

1982 \& 10

1983 R II

1982 R $\quad$ iA

1982 R iA

1982 R iA

1982 R iA

1982 R IA

1982 R iA

1983 \& 11

$1982 R \quad 10$

1982 R $1 \mathrm{~A}$

1982 R IA

$1982 R \quad$ in

$1982 R \quad$ in

$1982 R \quad 1 A$

1982 R iA

1983 R iA

$1982 R \quad 10$

1982 R $\quad 1 A$

1982 R IA 
WHC-EP-0719

This page intentionally left blank.

A.5-6 
WHC-EP-0719

APPENDIX A.6

HAZARDOUS CONSTITUENTS OF FIFTY-FIVE-GALLON

DRUMS CONTAINING TRANSURANIC WASTE

A. 6-1 
WHC-EP-0719

This page intentionslly left blank.

A.6-2 


\section{HAZARDOUS CONSTITUENTS OF FIFTY-FIVE-GALLON DRUMS CONTAINING TRANSURANIC WASTE}

The presence of hazardous constituents in a radioactive waste drum designates the waste as "Mixed" (primary waste code "M"). In this subappendix the hazardous contents of 55-gal drums generated at Babcock and Wilcox are sorted by storage facility.

Information concerning the hazardous constituents of waste containers was not required before 1986. During the R-SWIMS data reentry program in the mid-1980's, an attempt was made to add any available information on the hazardous materials present; however, this information was limited. 


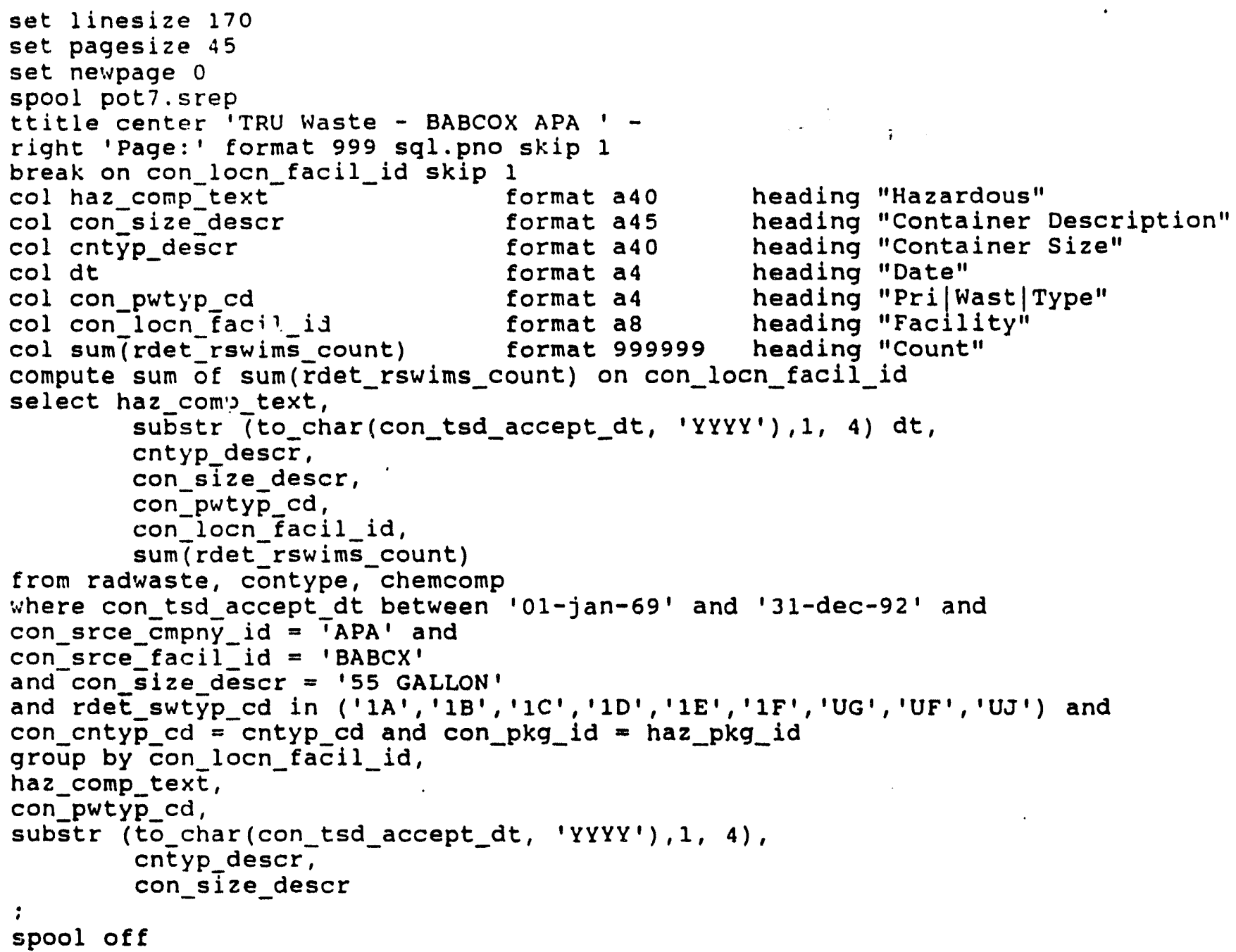


$D$ Hazardous

on in
IRU Haste - BABCOX APA

Date Container Size

Container Description

1981 METAL DRUAS, BarRELS, KEGS
Pri

Iype facility count

n $218 \mathrm{sec}$, n................
Page: 1 
WHC-EP-0719

This page intentionally left blank.

A.6-6 
WHC-EP-0719

APPENDIX A.7

HAZARDOUS CONSTITUENTS OF TRANSURANIC WASTE CONTAINERS OTHER THAN FIFTY-FIVE-GALLON DRUMS 
WHC-EP-0719

This page intentionally left blank.

A.7-2 


\section{HAZARDOUS CONSTITUENTS OF TRANSURANIC WASTE CONTAINERS OTHER THAN FIFTY-FIVE-GALLON DRUMS}

The presence of hazardous constituents in a radioactive waste drum designates the waste as "Mixed" (primary waste code "M"). No hazardous constituents are listed in containers other than 55-gal drums generated at Babcock and Wilcox; therefore, this run did not reveal any hazardous information. 


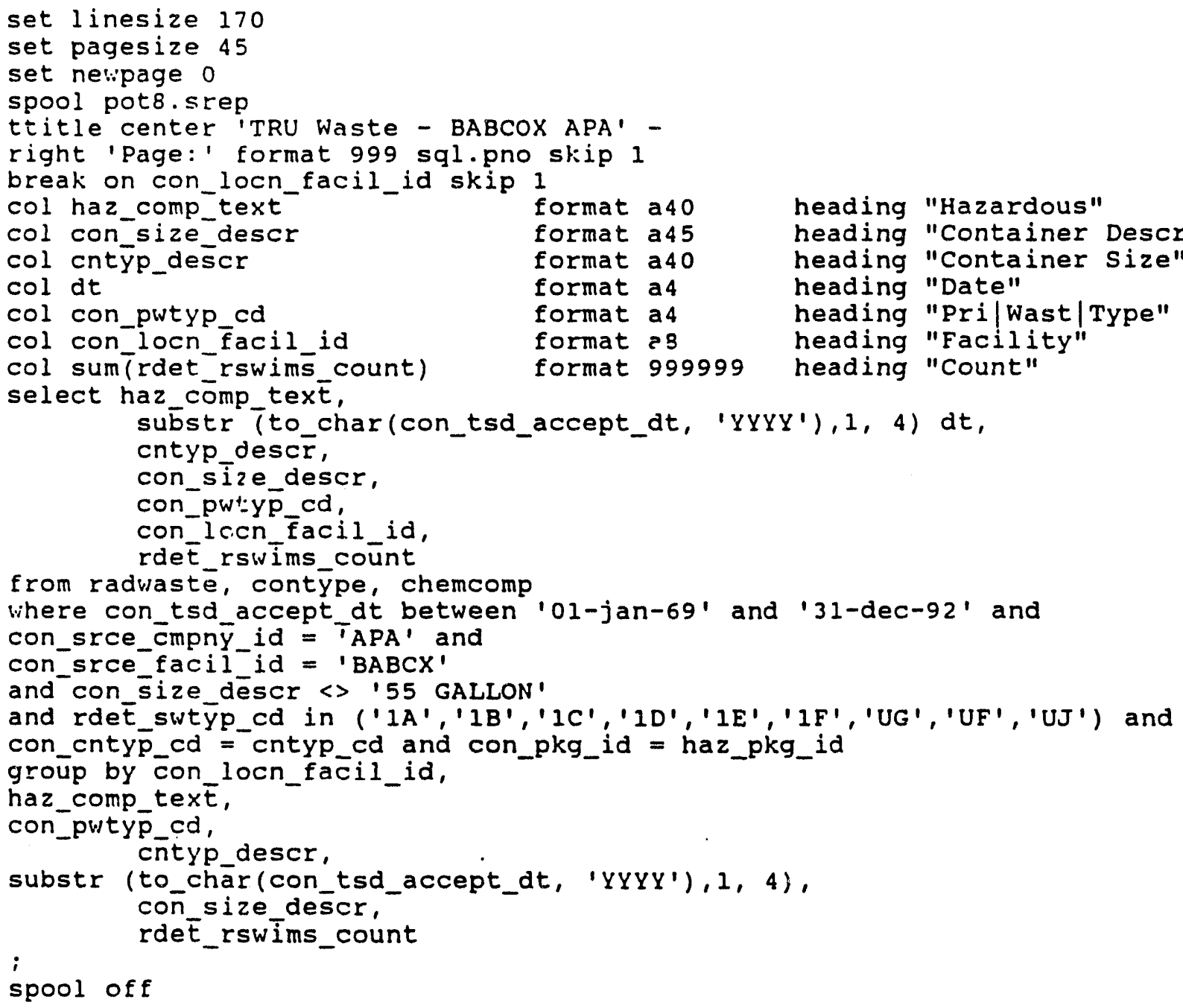




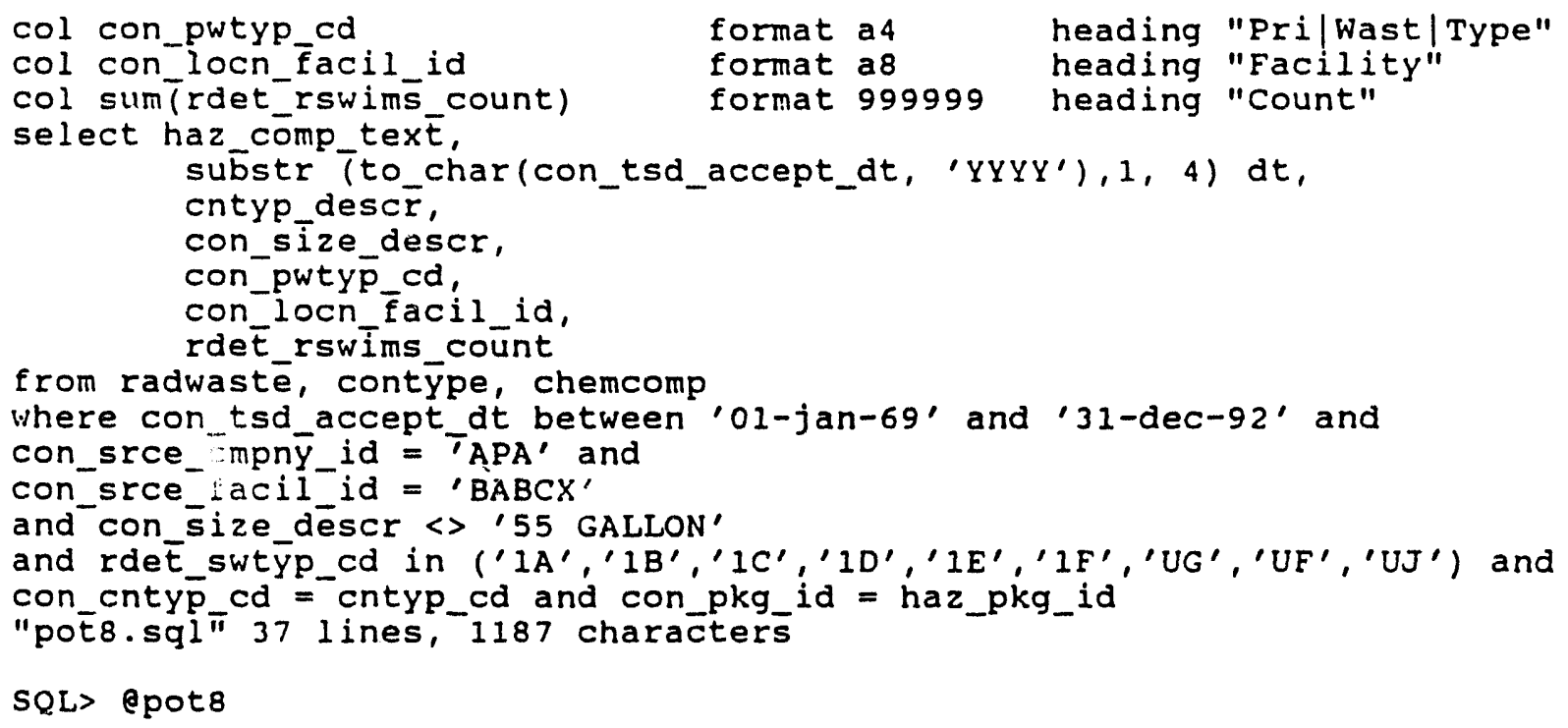

SQL> epot8

no rows selected

SQL> 
WHC-EP-0719

This page intentionally left blank.

A. 7-6 
WHC-EP-0719

APPENDIX A.8

ISOTOPES LISTED IN FIFTY-FIVE-GALLON DRUMS CONTAINING TRANSURANIC WASTES 
WHC-EP-0719

This page intentionally left blank.

A.8-2 


\section{ISOTOPES LISTED IN FIFTY-FIVE-GALLON DRUMS \\ CONTAINING TRANSURANIC WASTES}

This subappendix contains a listing of the SWITS isotope information for TRU waste from Babcock and Wilcox stored in 55-gal drums. The isotope field in SWITS contains several types of information as follows:

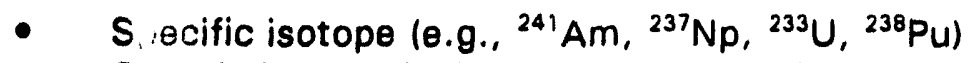

- Generic isotope listings (e.g., Pu, uranium-enriched, uranium-depleted)

- $\quad{ }^{239} \mathrm{Pu}$ Fissile Gram Equivalents ( ${ }^{239} \mathrm{Pu}$ FSL GR equiv)

- Total alpha

- Total beta/gamma.

This computer run contains the isotope field listing along with the number of TRU waste drums with that listing. The run is sorted by storage facility and year. 


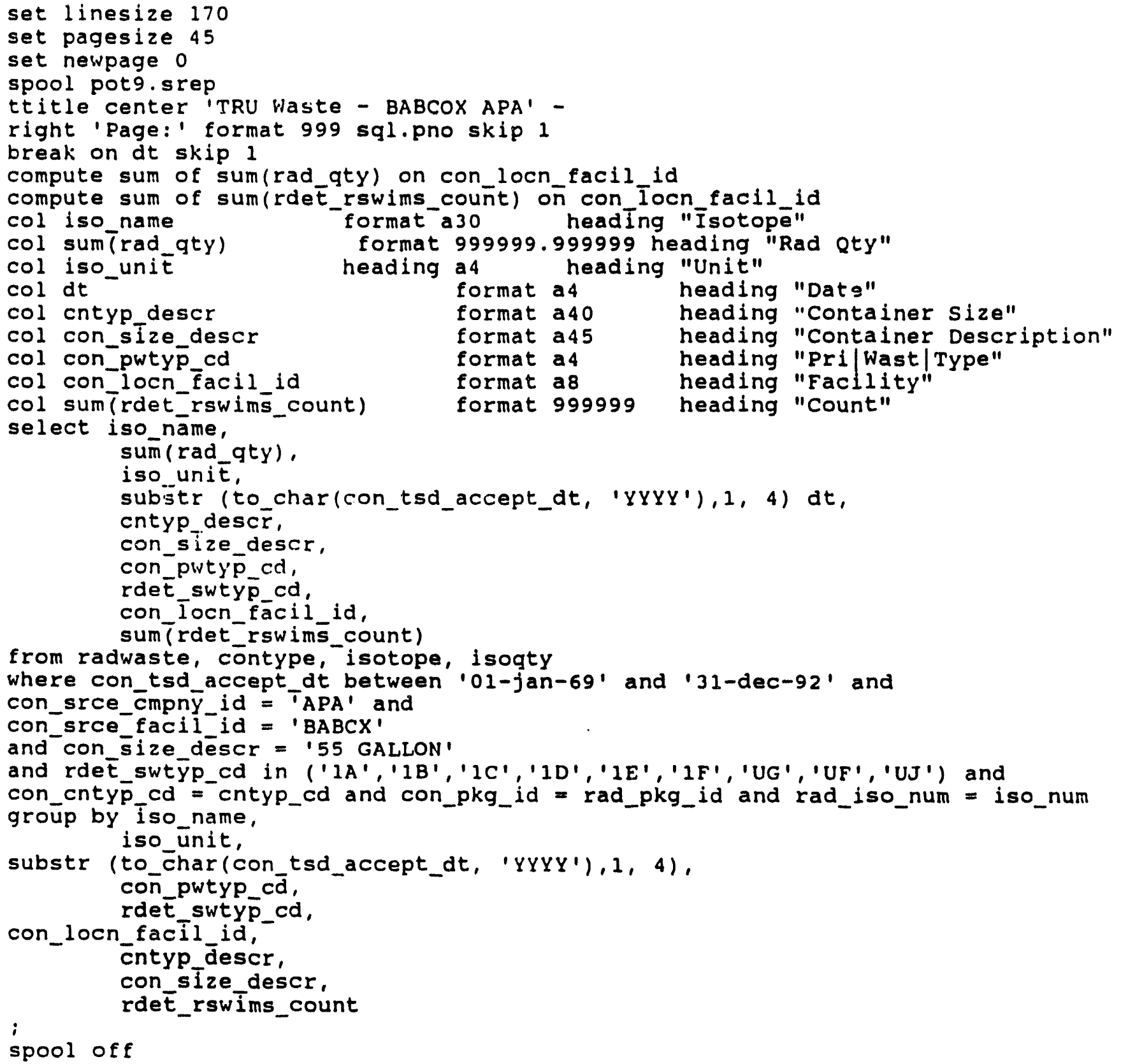




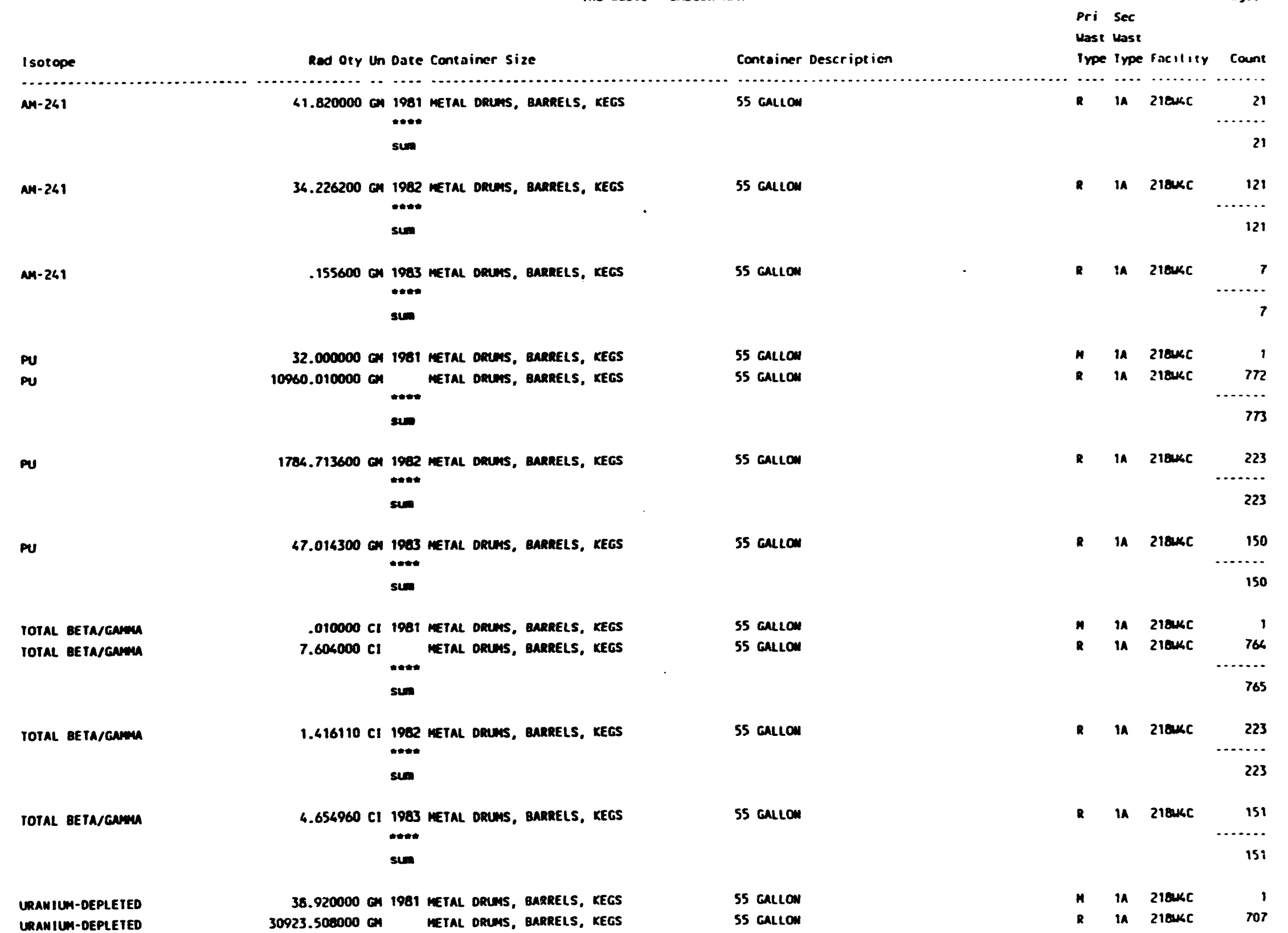




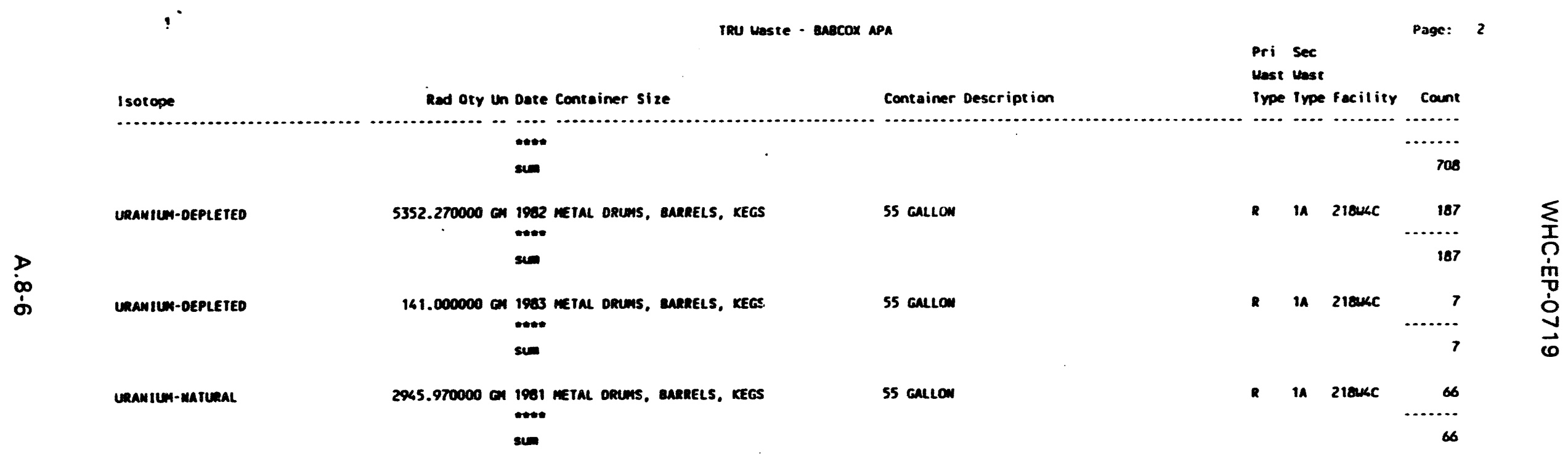

16 rous selected. 
WHC-EP-0719

APPENDIX A.9

ISOTOPES LISTED IN TRANSURANIC CONTAINERS

OTHER THAN FIFTY-FIVE-GALLON DRUMS

A.9-1 
WHC-EP-0719

This page intentionally left blank.

A.9.2 


\section{ISOTOPES LISTED IN TRANSURANIC CONTAINERS OTHER THAN FIFTY-FIVE-GALLON DRUMS}

This subappendix contains a listing of the SWITS isotope information for TRU waste from Babcock and Wilcox stored in containers other than 55-gal drums. The isotope field in SWITS contains several types of information as follows:

- Specific isotope (e.g., $\left.{ }^{241} \mathrm{Am},{ }^{237} \mathrm{~Np},{ }^{233} \mathrm{U},{ }^{238} \mathrm{Pu}\right)$

- Generic isotope listings (e.g., Pu, uranium-enriched, uranium-depleted)

- ${ }^{239}$ Pu Equivalent Curies (PE-CI)

- Total alpha

- Total beta/gamma

- PE-Ci (Pu equivalent curies).

This computer run contains the isotope field listing along with the number of TRU waste containers with that listing. The run is sorted by storage facility and year. 


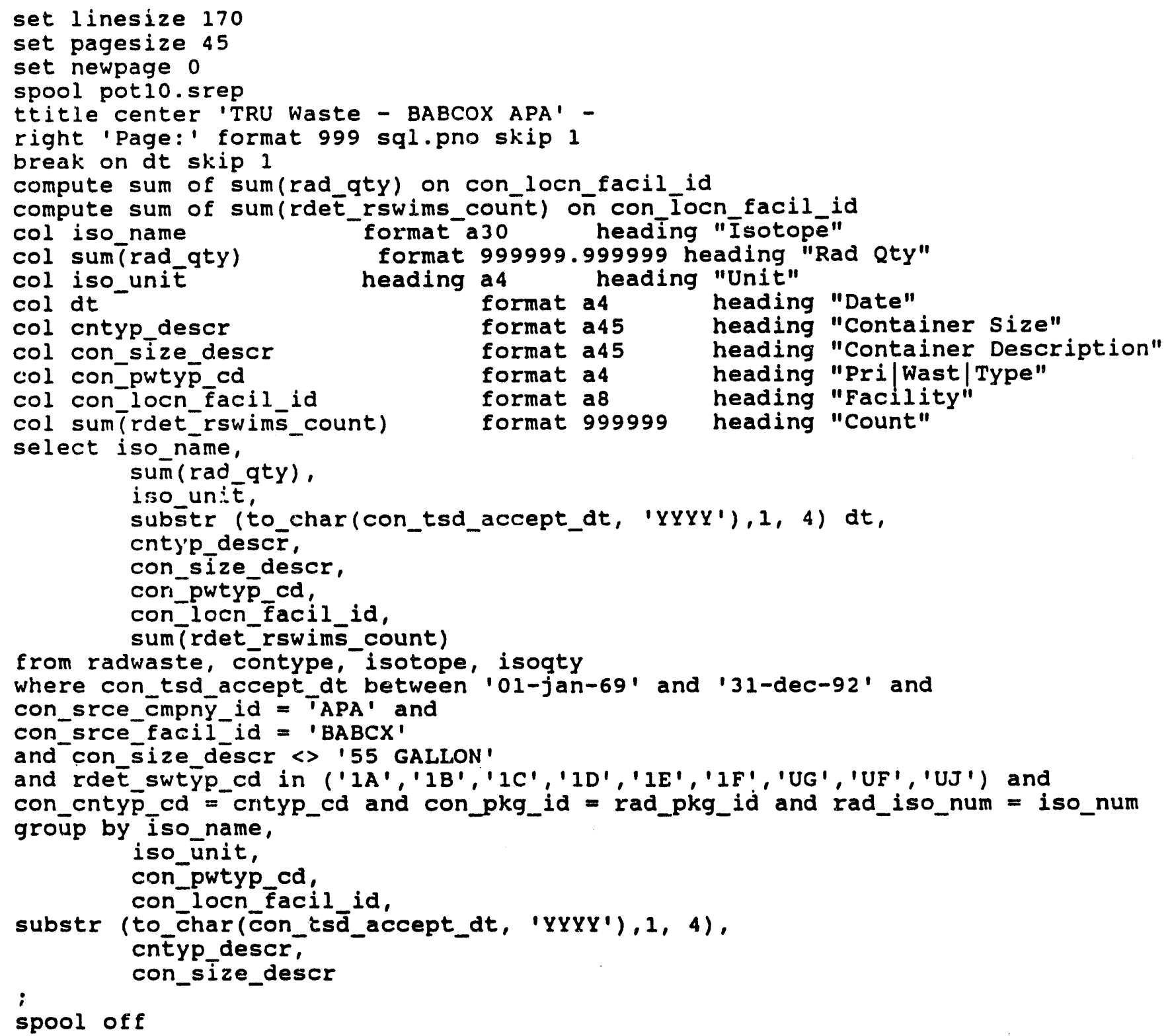




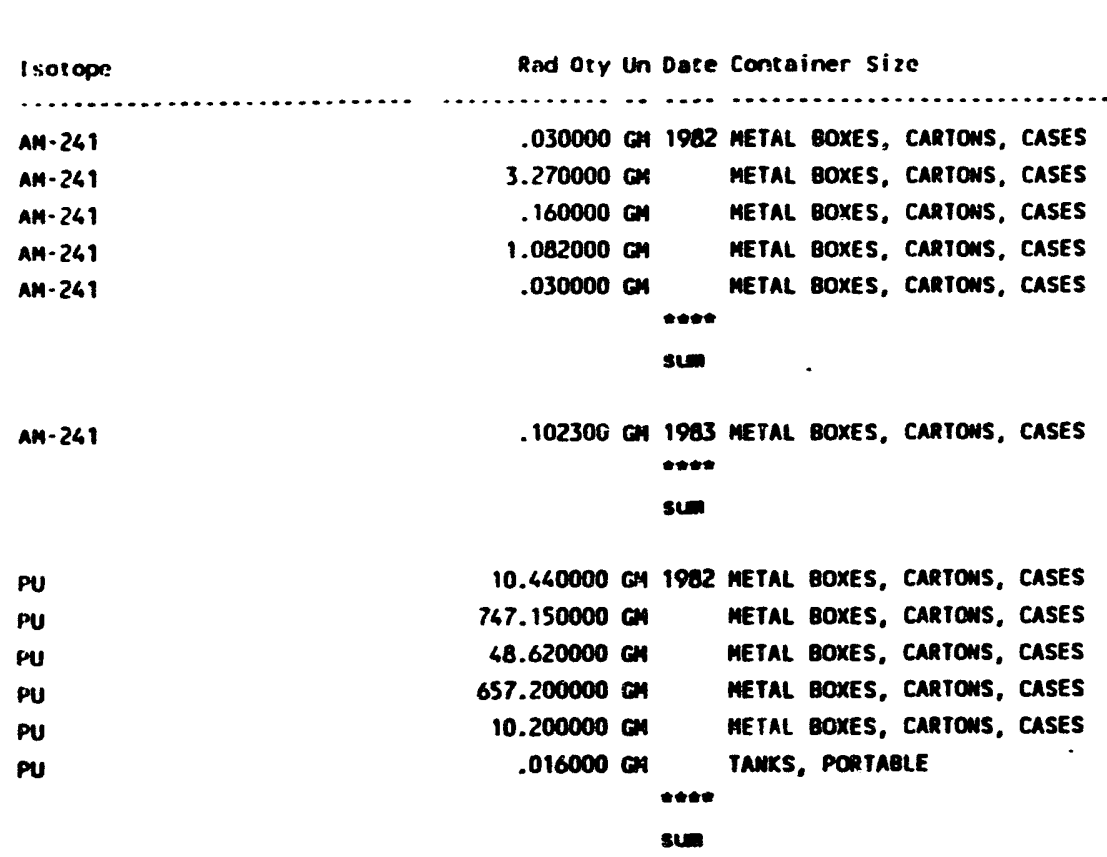

TOTAL BETA/GNOA TOTAL BETAJCAMA TOTAL BETA/GAMEA TOTAL BETA/CAMPA TOTAL BETA/GAMPIA TOTAL BETNGANEA

TOTAL BETA/CAMMA

URAMIUM-DEPLETED URAMIUM-DEPLETED
221.300100 OU 1903 METAL BOXES, CARTOWS, CASES .tin

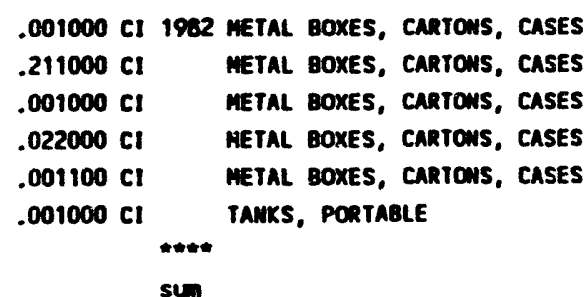

40.676000 CI 1983 METAL BOXES, CARTOWS, CASES ton."

sis

31.320000 ON 1962 METAL BOXES, CARTOWS, CASES 2240.000000 GM METAL BOXES, CARTOMS, CASES
Container Description

Pri

Last Iype facility count $4=5=6$

$5 * 5 * 7$

$5.5=0$

$5.4 * 5.6 * 6.8$

60607

$\begin{array}{rrr}R & 21844 C & 1 \\ R & 21846 C & 7 \\ R & 21844 C & 1 \\ R & 21844 C & 4 \\ R & 21844 C & 2 \\ & & \ldots . . . \\ & & 15\end{array}$

$5.4 * 5.6 * 6.8$

218w4C

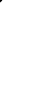

\section{$4=5 * 6$}

$5=5 * 7$

$5.5 * 9$

$5.4=5.6 * 6.8$

6*6"7

$4 \div 4$

$5.4 * 5.6 * 6.8$

4*5*6

5*5*7

$5 * 5 * 9$

$5.4 * 5.6 * 6.8$

6*6"7

$4=4$

$5.4 * 5.6 * 6.8$

218u4C

218w4C

218u4C

218u4C

218u4C

R 21BWhC

'

1
7
1
11
2
1
23

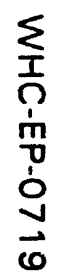

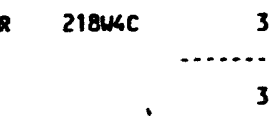

218U4C

218w4C 7

R 21844C 1

218u4C 11

218u4C

R $21844 C$

R $21844 C$

3

3

$4=5 * 6$

$5=5 * 7$

$\begin{array}{ll}218 H 4 C & 1 \\ 218 H 4 C & 7\end{array}$ 
TRU Waste - BABCOX APA

Red oty Un Date Container Size

Isotope

URAWIUN-DEPLETED

URAMIUH-DEPLETED

URAMILA-DEPLETEO

URAMIUM-DEPLETED
$665.800000 \mathrm{CH} 1983$ WETAL BOXES, CARTOWS, CASES

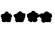

$145.800000 \mathrm{CM} 1962$ metal BOXES, CARTONS, CASES

$1972.550000 \mathrm{CM}$ METAL BOXES, CARTOWS, CASES

30.600000 CH DET BOXES, CARTONS, CASES

sin

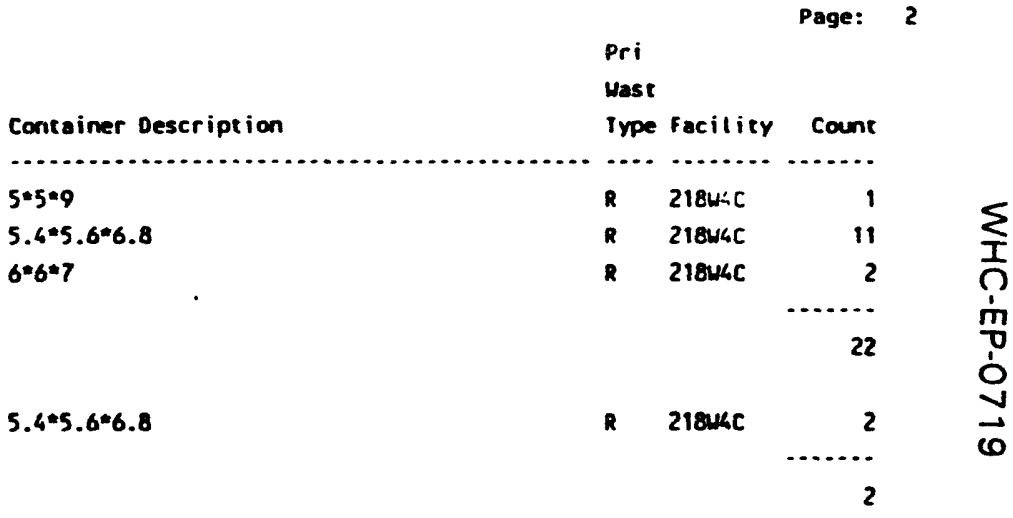

26 rows selected. 
WHC-EP-0719

APPENDIX B

BABCOCK AND WILCOX WASTE SUMMARY TABLE

B-1 
WHC-EP-0719

This page intentionally left blank.

B-2 


\section{BABCOCK AND WILCOX WASTE SUMMARY TABLE}

Table B-1 is a summary of Babcock and Wilcox attributed in SWITS database to building and generators other than Babcock and Wilcox (i.e., 234-5Z, 325, 340). The data that comprise this table was taken from the SWBRs that denote the waste as originating from Babcock and Wilcox, but having undergone some form of custody change, and therefore being buried as waste attributed to a generator other than Babcock and Wilcox on the SWITS database. 


\begin{tabular}{|c|c|c|c|c|c|}
\hline SWmber. & $\begin{array}{l}\text { Number of: } \\
\text { Containers: }\end{array}$ & Decolved & occeptod & $\begin{array}{l}\text { (sotopes } \\
\text { (g/Puil }\end{array}$ & Physicd comtents \\
\hline WH-1496" & 8 drums & 06-27-77 & 06-27-77 & 536 & Combustible misc. room and hood waste \\
\hline WH-1496" & 1 drum & $06-27-77$ & $06-27-77$ & 38 & Combustible misc. room and hood waste \\
\hline WH-744 & 1 drum & $05-17-78$ & $05-22-78$ & 47 & Combustible analytical waste \\
\hline WH-744A & 27 drums & $05-17-78$ & $05-16-79$ & 907 & Noncombustible analytical waste \\
\hline WH-752 & 1 drum & $05-24-78$ & $10-29-78$ & 8 & Combustible analytical waste \\
\hline WH-752A & 10 drums & $05-24-78$ & 05-18-79 & 344 & Noncombustible analytical waste \\
\hline WH-752B & 1 drum & $05-24-78$ & $11-04-80$ & 60 & Noncombustible analytical waste \\
\hline WH-753 & 13 drums & $06-07-78$ & $10-29-78$ & 115.4 & Combustible analytical waste \\
\hline WH-753A & 22 drums & 06-07-78 & 05-18-79 & 857 & Noncombustible analytical waste \\
\hline WH-754 & 35 drums & $07-26-78$ & $10-29-78$ & 251.9 & Combustible analytical waste \\
\hline WH-754A & 5 drums & $07-26-78$ & 05-18-79 & 208 & Noncombustible analytical waste \\
\hline WH-782 & 12 drums & $08-16-78$ & $11-21-78$ & 865 & Combustible analytical waste \\
\hline WH-783 & 36 drums & $09-27-78$ & $05-01-79$ & 319.3 & Combustible analytical waste \\
\hline WH-783A & 5 drums & $09-27-78$ & $05-18-79$ & 215.4 & Noncombustible analytical waste \\
\hline WH-784 & 1 drum & $02-14-79$ & 05-03-79 & 127 & Combustible analytical waste \\
\hline WH-785 & 31 drums & $07-25-79$ & $08-11-79$ & 100.5 & Combustible analytical waste \\
\hline WH-785A & 11 drums & $07-25-79$ & $05-16-80$ & 21 & Noncombustible analytical waste \\
\hline WH-786 & 42 drums & $08-22-79$ & 09-15-79 & 7 & $\begin{array}{l}\text { Combustible analytical waste: } 50 \% \text { plastic, } \\
50 \% \text { filter media }\end{array}$ \\
\hline WH-1027 & 42 drums & 09-19-79 & $10-15-79$ & 113.5 & $\begin{array}{l}\text { Combustible analytical waste: } 50 \% \text { filter } \\
\text { media, } 20 \% \text { wood, } 20 \% \text { cloth, } 10 \% \text { paper }\end{array}$ \\
\hline
\end{tabular}

234-5Z Building.

'340 Building.

$\mathbf{g}=$ grams

misc. $=$ miscellaneous

SWBR = Solid Waste Burial Record. 
DISTRIBUTION

\section{Number of copies}

\section{OFFSITE}

6

Los Alamos Technical Associates

8633 Gage Boulevard

Kennewick, Washington 99336

J. A. Pottmeyer (3)

M. I. Weyus-Rollosson

K. D. Dicenso

D. S. Delorenzo

1

Babcock and Wilcox

Nuclear Environmental Services, Inc.

Route \#1, Box 355

Vandergrift, Pennsylvania 15690

M. J. Straub

\section{ONSITE}

4

U.S. Department of Energy-

Richland Field Office

R. M. Gordon

R. F. Guercia (2)

R3-80

Public Reading Room

Westinghouse Hanford Company
J. D. Anderson
C. L. Bergeson
B. J. Broomfield
D. M. Caum
J. A. Demiter
D. R. Duncan (10)
W. O. Greenhalgh
K. L. Hladek
D. M. Johnson
B. A. Mayancsik
M. M. McCarthy
W. W. Olson
J. G. Riddelle
R. J. Roberts

N3-13

H1-60

T3-04

H5-33

L5-31

H5.33

L5-31

N3-13

$\mathrm{H} 5-33$

H5-33

G1-19

H4-70

$\mathrm{H} 5.33$

N3-13 
WHC-EP-0719

\section{DISTRIBUTION (cont)}

Number of copies

\section{ONSITE}

J. A. Swenson (2)

Central Files

G6-45

Document Processing and

Distribution (2)

Information Release

Administration

L8-04

L8.04

L8.07

Distr-2 


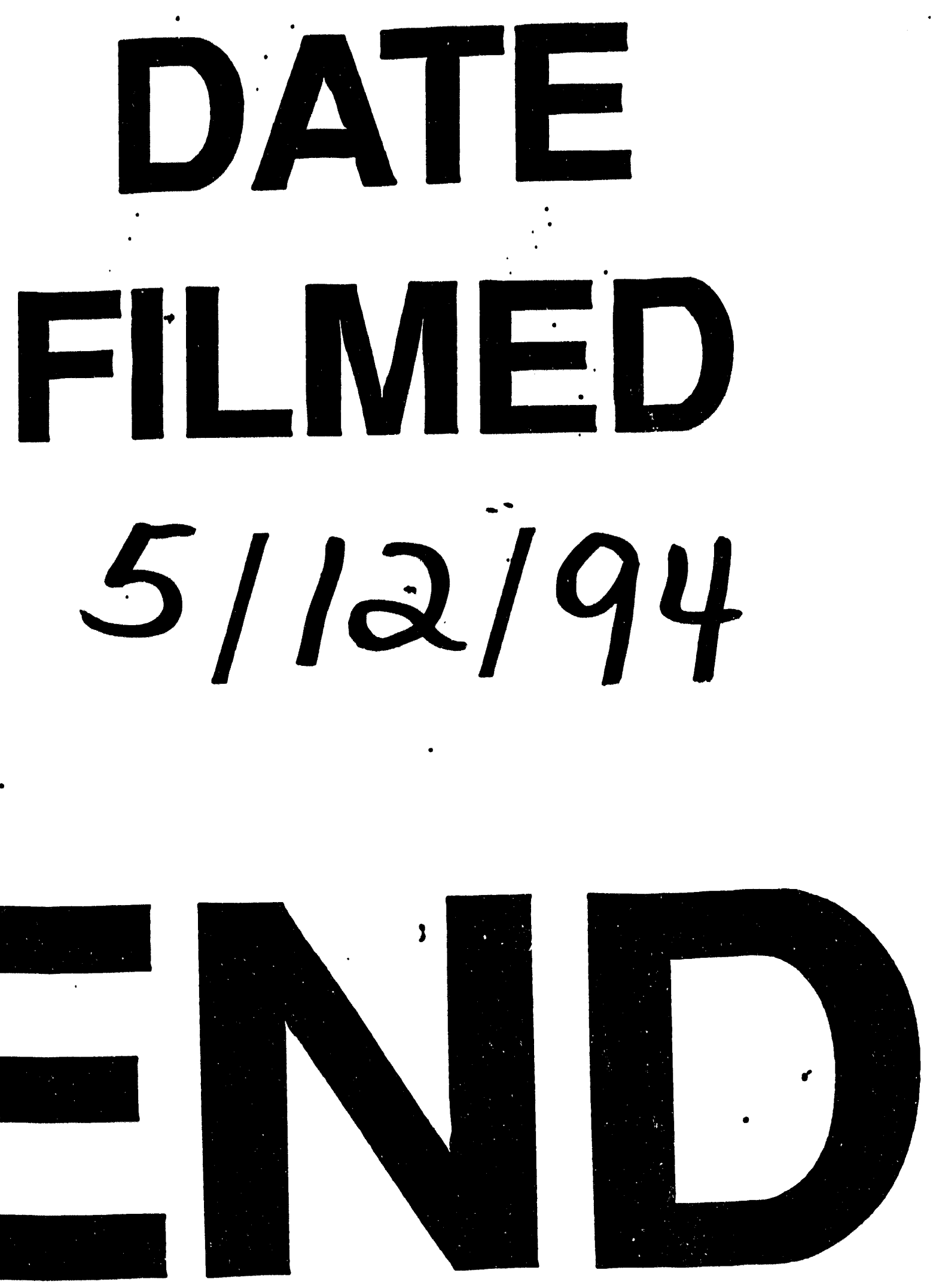


